João Rafael da Conceição

O Serviço Social no sistema prisional:

Reflexões acerca do trabalho profissional dos assistentes sociais nas prisões do Rio de Janeiro.

\begin{abstract}
DISSERTAÇÃO DE MESTRADO
Dissertação apresentada ao Programa de Pósgraduação em Serviço Social da PUC-Rio como requisito parcial para obtenção do grau de Mestre em Serviço Social.
\end{abstract}

Orientadora: Prof. Dra. Ariane Rego de Paiva 
João Rafael da Conceição

\title{
O Serviço Social no sistema prisional: Reflexões acerca do trabalho profissional dos assistentes sociais nas prisões do Rio de Janeiro.
}

\begin{abstract}
DISSERTAÇÃO DE MESTRADO
Dissertação apresentada ao Programa de Pósgraduação em Serviço Social da PUC-Rio como requisito parcial para obtenção do grau de Mestre em Serviço Social. Aprovada pela Comissão Examinadora abaixo assinada
\end{abstract}

Prof. ${ }^{\text {a }}$ Ariane Rego de Paiva Orientadora Departamento de Serviço Social - PUC Rio

Prof. a Fátima da Silva Grave Ortiz Escola de Serviço Social - UFRJ

Prof. ${ }^{\text {a }}$ Valéria Lucilia Forti Faculdade de Serviço Social - UERJ

Prof. ${ }^{\text {a }}$ Inez Terezinha Stampa Departamento de Serviço Social - PUC Rio 
Todos os direitos reservados. É proibida a reprodução total ou parcial do trabalho sem autorização da universidade, do autor e da orientadora.

João Rafael da Conceição

Assistente Social e especialista em Gestão Urbana e Saúde. Mestrando em Serviço Social pela Pontifica Universidade Católica do Rio de Janeiro. Especializando em Saúde Pública pela Fundação Oswaldo Cruz. Graduado em Serviço Social pela Universidade Federal do Estado do Rio de Janeiro (2016). Membro da Comissão de Direitos Humanos, desde 2015, do Conselho Regional de Serviço Social do estado do Rio de Janeiro (CRESS/7a Região) e foi representante externo do CRESS, em 2017, no Conselho de Segurança Pública do Estado do Rio de Janeiro (CONSPERJ). Tem experiência na área de Serviço Social, com ênfase em Serviço Social no campo sociojurídico.

Ficha Catalográfica

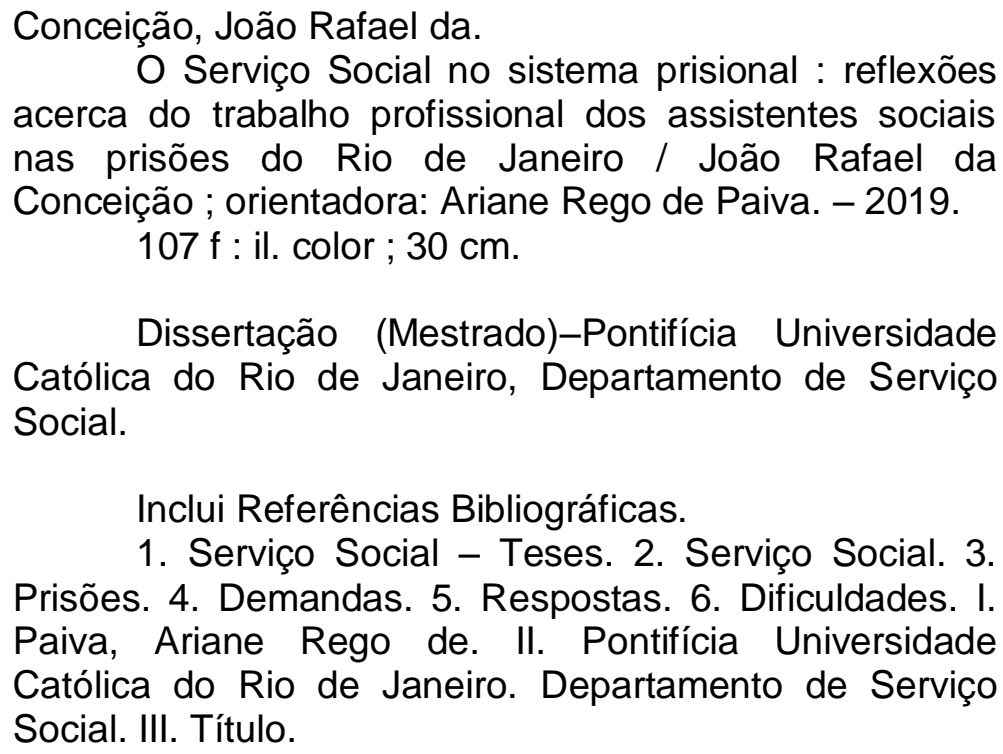

1. Serviço Social - Teses. 2. Serviço Social. 3. Prisões. 4. Demandas. 5. Respostas. 6. Dificuldades. I. Paiva, Ariane Rego de. II. Pontifícia Universidade Católica do Rio de Janeiro. Departamento de Serviço Social. III. Título. 
Para minha família, Kerolin Dias, Victor Bryan, Pedro

Henrique e Maria Cecília, Por serem motor e combustível na minha vida.

À classe trabalhadora, pela resistência e pelos interesses históricos:

Sua luta me possibilitou ingressar e terminar esses estudos. 


\section{Agradecimentos}

Esse período de elaboração da dissertação foi bastante conturbado: decepções, tristezas, angústias, ansiedades e medos me assolaram. Certamente, sem algumas pessoas eu não poderia ter chegado até o final. Afinal, nunca se vence uma guerra sozinha. Toda vitória é expressão de uma coletividade.

Embora seja o meu nome que se encontra como responsável da dissertação que se segue, ela é fruto das minhas lutas, dos diálogos com familiares, amigos e conhecidos, da capacidade de universalizar do humano-génerico e das minhas vivências.

Correndo o risco de esquecer algumas pessoas não menos importantes nesse período da minha vida, quero expor os meus singelos agradecimentos:

Aos trabalhadores, sua resistência (consciente ou inconscientemente) me permitiu acessar a universidade, permanecer e concluir mais uma etapa. Esse estudo está a serviços de nossa classe!

Ao Partido Comunista Brasileiro e a União da Juventude Comunista, organizações políticas mais antigas em defesa dos interesses históricos da classe trabalhadora no Brasil. Pertencer às fileiras dessas organizações fez/faz de mim parte de uma luta real e efetiva pela transformação radical dessa sociedade: ser comunista é ser abolicionista penal!

À minha família, sem a qual não teria forças: Kerolin Dias, Victor Bryan, Pedro Henrique e Maria Cecília amo muito vocês. São responsáveis por manterem acesas a minha esperança e meus sonhos.

À minha mãe, Rosemere da Conceição, e ao meu padrasto, Clóvis Ferreira, por tudo que fizeram em minha vida. Amor que não se mede.

Aos meus valorosos amigos e amigas, em especial Elton Alcantara, Natalia Lorena, Vanessa Dornelas, Luisa Maria, Paula Monique e Renata Oliveira, por mesmo sem saber (ou sabendo) foram fundamentais nesse percurso tortuoso, repleto de dúvidas e incertezas quanto a possibilidade de chegar até o final.

Aos assistentes sociais da SEAP, pela dedicação e defesa do projeto profissional em um campo tão hostil, como as prisões.

À minha orientadora, Ariane Rego, a pessoa que acreditou em mim mesmo quando eu próprio não conseguia e que apostou nesse trabalho. Com quem pude aprender que é possível sim fazer pós-graduação de forma leve e saudável. Para ela, meu carinho, respeito e admiração.

À minha banca, Fátima Grave, Valéria Forti e Inez Stampa, pelas brilhantes contribuições na qualificação e certamente na apresentação. Toda crítica de vocês é construtiva e necessária. Agradeço imensamente!

O presente trabalho foi realizado com apoio da Coordenação de Aperfeiçoamento de Pessoal de Nível Superior - Brasil (CAPES) - Código de Financiamento 001. 


\section{Resumo}

Conceição, João Rafael. O Serviço Social no sistema prisional: reflexões acerca do trabalho profissional dos assistentes sociais nas prisões do Rio de Janeiro. Rio de Janeiro, 2019. 107p. Dissertação de Mestrado Departamento de Serviço Social, Pontifícia Universidade Católica do Rio de Janeiro.

Estudo de abordagem qualitativa, que visa refletir sobre demandas e respostas profissionais do Serviço Social no sistema prisional do Rio de Janeiro. Utilizaram-se os dados da pesquisa do Conselho Regional de Serviço Social $7^{\mathrm{a}}$ Região - Rio de Janeiro (CRESS/RJ) "o Serviço Social no campo sociojurídico: subsídios para o exercício profissional", em específico seu apêndice referente ao sistema penitenciário. O percurso reflexivo dividiu-se em três momentos: (i) de breve análise da constituição da população a ser encarcerada (a superpopulação relativa), das funcionalidades da prisão ao capital e dos movimentos de reforma prisional; (ii) do Serviço Social no sistema prisional brasileiro e a institucionalização da profissão nas prisões fluminense; e (iii) da reflexão dos dados e informações que foram agregadas e categorizadas em: (a) relacionada às demandas, "demandante" e "demanda"; (b) relacionada às respostas profissionais: "ações burocráticas", "conhecimento", "ação profissional", e "instrumentos e técnicas"; (c) relacionada às dificuldades de trabalho, "condições de trabalho", "correlação de forças" e "subalternidade da profissão"; (d) relacionada às violações de direitos, "agente violado", "arbítrio", "inobservância da lei” e "privação de serviços"; e (e) relacionada às possibilidades de trabalho, “articulação intraprofissional”, "articulação política" e "rede socioassistencial”.

\section{Palavras-chave:}

Serviço Social; prisões; demandas; respostas; dificuldades; violação de direitos; e possibilidades. 


\section{Resumen}

Conceição, João Rafael. Trabajo social en el sistema penitenciario: reflexiones sobre el trabajo profesional de los trabajadores sociales en las cárceles de Río de Janeiro. Río de Janeiro, 2019. 107p. Tesis de maestría Departamento de Trabajo Social, Pontificia Universidad Católica de Río de Janeiro.

Estudio del enfoque cualitativo, cuyo objetivo es reflexionar sobre las demandas y respuestas profesionales del trabajo social en el sistema penitenciario de Río de Janeiro. Datos de la encuesta realizada por el Consejo Regional de Trabajo Social $7^{\mathrm{a}}$ Región - Río de Janeiro (CRESS / RJ) "Trabajo social en el campo socio-legal: subsidios para la práctica profesional", específicamente su apéndice que se refiere al sistema penitenciario. El curso reflexivo se dividió en tres momentos: (i) un breve análisis de la constitución de la población a ser encarcelada (superpoblación relativa), las funcionalidades de la prisión a los movimientos de reforma de la capital y la prisión; (ii) Trabajo social en el sistema penitenciario brasileño y la institucionalización de la profesión en las cárceles de Río de Janeiro; y (iii) la reflexión de los datos y la información que se agregaron y categorizaron en: (a) relacionados con las demandas, el "demandante" y la "demanda"; (b) relacionado con las respuestas profesionales: "acciones burocráticas", "conocimiento", "acción profesional" e "instrumentos y técnicas"; (c) relacionado con dificultades laborales, "condiciones de trabajo", "correlación de fuerzas" y "subordinación de la profesión"; (d) relacionado con violaciones de derechos, "agente violado", "agencia", "incumplimiento de la ley" y "privación de servicios"; y (e) relacionadas con las posibilidades de trabajo, la "articulación intraprofesional", la "articulación política" y la "red de asistencia social".

Palabras clave:

Trabajo social; cárceles demandas respuestas; dificultades violación de derechos; y posibilidades. 


\section{Sumário}

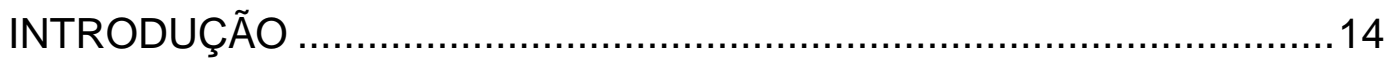

PERCURSO METODOLÓGICO ...........................................................15

1. PARA ALÉM DAS PRISÕES: sociedade capitalista e prisões. .............20

1.1. As bases históricas da população destinada às prisões: acumulação primitiva e superpopulação relativa..................................21

1.2. Funcionalidades das prisões ao capital. .......................................25

1.2.1. As reais funções das prisões no sistema capitalista. ...............29

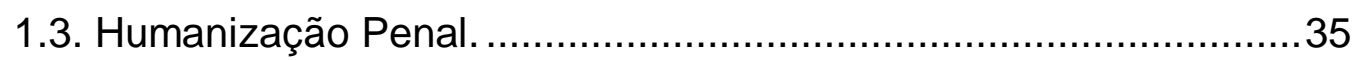

1.3.1. Humanização: um debate ontológico......................................35

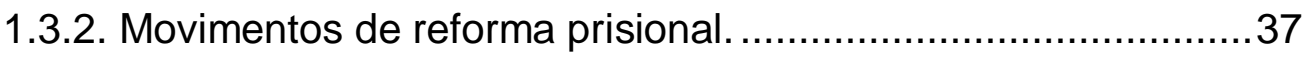

2. SERVIÇO SOCIAL E PRISÕES. .................................................... 41

2.1. As requisições institucionais das prisões ao Serviço Social

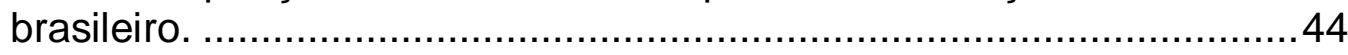

2.2. A institucionalização do Serviço Social nas prisões fluminense.....52

3. O TRABALHO PROFISSIONAL SOB A ÓTICA DOS ASSISTENTES SOCIAIS DO SISTEMA PRISIONAL DO RIO DE JANEIRO ...................60

3.1. Demandas ao Serviço Social nas prisões do Rio de Janeiro. .........61

3.2. Resposta profissional às demandas postas.................................70

3.3. Dificuldades de trabalho nas prisões do Rio de Janeiro. .................81

3.4. Violação de direitos nas prisões a partir do olhar dos assistentes sociais.

3.5. As possibilidades de trabalho dos assistentes sociais nas prisões.

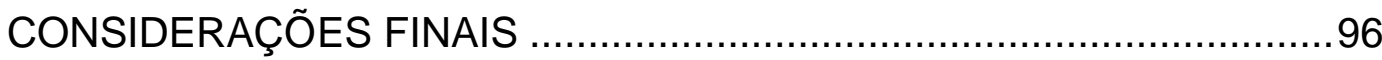

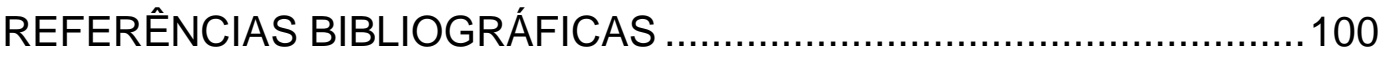




\section{Lista de siglas}

CAPES Coordenação de Aperfeiçoamento de Pessoal de Nível

CBAS Congresso Brasileiro de Assistentes Sociais

CFESS Conselho Federal do Serviço Social

CNPCP Conselho Nacional de Política Criminal e Penitenciária

CPB Código Penal Brasileiro

CRESS Conselho Regional de Serviço Social

CSS Coordenação de Serviço Social

CTC Comissão Técnica de Classificação

DEPEN Departamento Penitenciário Nacional

DETRAN Departamento de Trânsito do Estado do Rio de Janeiro

DIC Diretoria de Identificação Civil

EGP Escola de Gestão Penitenciária

ENPESS Encontro Nacional de Pesquisadores/as em Serviço Social

Grupo de Integração e Discussão de Estagiárias do Serviço

GIDESS Social na Secretaria de Administração Penitenciária do Rio de Janeiro

IDH Índice de Desenvolvimento Humano

LEP Lei de Execução Penal

ONG Organização Não governamental

ONU Organização das Nações Unidas

PPGSS Programas de Pós-Graduação em Serviço Social

PUC Rio Pontifícia Universidade Católica do Rio de Janeiro

RPERJ Regulamento do Sistema Penal do Estado do Rio de Janeiro

STF Supremo Tribunal Federal

UF Unidade Federativa 


\section{Lista de tabelas}

TABELA I Atribuições e competências profissionais no sistema 77 prisional. 


\section{Lista de quadros}

QUADRO I Dados sobre a participação no seminário 17 referente ao sistema prisional (2015).

QUADRO II Mudanças no organograma referente ao serviço 55 social, no período entre 1954 e 1975, e as respectivas coordenações.

QUADRO III Marcos históricos relacionados ao Serviço Social, 56 entre 1975 e 2007.

QUADRO IV Dos eixos e temas da análise documental. 61

QUADRO V Fragmentos de respostas em relação aos eixos 74 de respostas às demandas, dificuldades, violação de direitos e possibilidades de trabalho.

QUADRO VI Comparativo do quantitativo profissional, seus 86 vínculos e o quantitativo carcerário. 


\section{Lista de gráficos}

GRÁFICO I Perfil profissional por sexo e faixa etária. 
Um brinde à história

Eu brindo a história

Mas não qualquer uma Àquela que não é contada

Pela própria história.

Brindo a luta na cidade e no campo

De Dandara a Chico Mendes

Mariguella a Marielle

Brindo a luta nos dias ensolarados ou de chuva

De seca e escassez

De Maria Bonita a minha avó, retirante "invisível"

Brindo a luta pela sobrevivência

A mais dura resistência

Não brindo a resiliência

Brindo ao luto

Ora verbo, ora substantivo

Porém, sempre com sujeito

Brindo, por fim, aos totalmente esquecidos

Loucos e/ou bandidos

Pobres e negros

Homens e mulheres

João Rafael da Conceição 


\section{INTRODUÇÃO}

A quem serve as prisões? Quais as suas funções? E como é o cotidiano do assistente social nesse contexto? Essas indagações são norteadoras da dissertação que se apresenta.

Toda a sua construção analítica considera como elemento central a estrutura econômica da sociedade burguesa, sua polarização em classes antagônicas devido à propriedade privada dos meios de produção e subsistência e a necessidade histórica de controle sobre determinada fração da classe trabalhadora, em que profissões das Ciências Humanas e Sociais são requisitadas para operar esse controle dentro de suas competências e atribuições privativas, inclusive o Serviço Social - maior profissão de nível superior nas prisões (MINISTÉRIO DA JUSTIÇA E SEGURANÇA PÚBLICA, 2017).

Se por um lado o Serviço Social é a profissão de nível superior com o maior quantitativo de profissionais em atuação no sistema prisional brasileiro e a sua atuação é datada pelo menos desde a década de 1940 (GUINDANNI, 2001), por outro lado este lócus de atuação profissional recebe pouca atenção nas produções teóricas na área de Serviço Social.

Esse movimento de distância da profissão em relação à realidade prisional pode ser reflexo das hipóteses levantadas por Amaral (2016) acerca da cultura da emergência e/ou por Davis (2018) com o binômio presente-ausente. Amaral (2016) expressa que as prisões são lembradas apenas em casos de emergência, ou em situações de agudização das contradições próprias ao fenômeno. Davis (2018) realiza a assertiva de que quando o assunto é prisão a sociedade tende a reconhecer a sua existência (presença) ao mesmo tempo em que se nega a discutila (ausência).

Esta dissertação, portanto, se situa no campo dos desafios à profissão de compreender seu trabalho no interior do sistema prisional, em especial nas unidades prisionais do Rio de Janeiro.

Ao se inserir no escopo de produções teóricas de um espaço ocupacional tão distante e presente, lembrado em momentos bem específicos, a dissertação propõe-se, em um primeiro instante, a apresentar as prisões para além delas mesmas, como particularidade de uma totalidade concreta, resgatando processos 
históricos que fomentaram a constituição da população a ser encarcerada e a divisão social e técnica do trabalho em seu interior, a partir de discursos oficiais e funcionalidades reais ao processo de acumulação e valorização do capital, que inclui movimentos de transformações nominados de reforma prisional. As reflexões propostas são fundamentalmente (ainda que não exclusivamente) a partir de Marx (1985; 1996a; 1996b), Baratta (2016), Serra (2007), Rusche e Kirchheirmer (2004), Davis (2018), Amaral (2016) e Oliveira (2016).

No segundo momento dos estudos, busca-se a apresentar o Serviço Social e sua institucionalização no sistema prisional do Rio de Janeiro, apreendendo requisições institucionais e a imagem social histórica da profissão no ambiente referido. Refletiu-se, nesse momento, a partir de Forti (2008), Santos (1987), Lemos (2010) e Bravin (2013).

E, por fim, sistematizam-se os eixos e os temas derivados da pesquisa realizada pelo Conselho Regional de Serviço Social - $7^{a}$ Região acerca do trabalho profissional nas prisões do Rio de Janeiro. A reflexão teórica foi subsidiada em especial por Iamamoto (2004), acrescentada das análises dos capítulos anteriores e da empiria acumulada na instituição.

A seguir descreve-se o percurso metodológico adotado na presente dissertação.

\section{PERCURSO METODOLÓGICO}

A abordagem da pesquisa é predominantemente qualitativa e de interesse exploratório. Como procedimentos, adotaram-se as pesquisas bibliográfica e documental.

Por pesquisa bibliográfica, compreende-se o levantamento de referências bibliográficas em livros e artigos científicos indicados pela orientadora e as obras clássicas das categorias e conceitos pertinentes ao estudo, assim como as produções encontradas no levantamento de teses e dissertações no banco de teses e dissertações da Coordenação de Aperfeiçoamento de Pessoal de Nível Superior (CAPES), especificamente na área de conhecimento do Serviço Social, entre 2013 e 2017, e dos artigos nos anais do Congresso Brasileiro de Assistentes Sociais (CBAS), de 2013 e 2016, e do Encontro Nacional de Pesquisadores em Serviço Social (ENPESS), de 2014 e 2016. Essa leve diferença temporal se deve ao fato 
que a realização dos eventos científicos em questão ocorre com periodicidades diferentes, sendo o CBAS trianual e o ENPESS bianual, assim como a referida plataforma não disponibiliza os arquivos das teses e dissertações dos anos anteriores ao de 2013.

Nesse levantamento, foram utilizados os termos/palavras-chave: abolicionismo penal; aprisionamento; cárcere; custódia; egresso; medida de segurança; pena; penitenciária/sistema penitenciário; punição; preso/presa; prisão; privação / privada / privativa de liberdade; e sistema prisional. O termo/palavra chave "Serviço Social" não foi utilizado por se tratar de banco de dados próprios da área de Serviço Social.

Pretende-se com esta pesquisa bibliográfica estudar a constituição da população a ser encarcerada (a superpopulação relativa), as funcionalidades da prisão ao capital, os movimentos de reforma prisional, o Serviço Social no sistema prisional brasileiro e a sua institucionalização nas prisões fluminense.

Com a pesquisa documental foram lidas e analisadas legislações pertinentes ao trabalho do assistente social no Rio de Janeiro, identificadas nas leituras bibliográficas, tais como a Lei de Execução Penal (LEP), o Código Penal Brasileiro (CPB), o Decreto Federal no 35.076 de 1954 e o Regulamento do Sistema Penal do Estado do Rio de Janeiro (RPERJ), os Relatórios Finais dos Encontros Nacionais do Conjunto CFESS-CRESS, de 2012 a 2018 ${ }^{1}$, e o questionário aplicado pelo Conselho Regional de Serviço Social $7^{a}$ Região - Rio de Janeiro (CRESS/RJ) na Oficina Demandas dos usuários e projeto de intervenção, em julho de 2015, na Escola de Gestão Penitenciária (EGP), que se tornou apêndice no documento do CRESS/RJ (2018) "o Serviço Social no campo sociojurídico: subsídios para o exercício profissional”.

Este apêndice se constituiu enquanto fonte primária de cinco questões abertas, a saber: (i) quais são as demandas; (ii) como você responde a essas demandas; (iii) quais são as dificuldades; (iv) o que você identifica como violação de direitos; e (v) quais são as possibilidades de trabalho frente a demanda e a violação de direitos.

Estas questões foram respondidas por 39 pessoas assim distribuídas: 19 assistentes sociais da Secretaria de Estado de Administração Penitenciária

\footnotetext{
${ }^{1}$ Tanto as legislações citadas quanto os relatórios em questão todos estão disponíveis na internet.
} 
(SEAP); 12 estagiários da SEAP; 08 outros (profissionais e estudantes não vinculados a SEAP), conforme o quadro I.

QUADRO I - Dados sobre a participação no seminário referente ao sistema prisional (2015)

\begin{tabular}{|l|c|}
\hline \multicolumn{1}{|c|}{ Respondente/seminário } & $\begin{array}{c}\text { Sistema Prisional } \\
29 / 07 / 2015\end{array}$ \\
\hline Assistentes Sociais & 19 \\
\hline Estagiários & 12 \\
\hline Outros & 08 \\
\hline Total & 39 \\
\hline
\end{tabular}

FONTE: Apêndice de CRESS/RJ (2018). Compilação Própria.

Em termos de pertinência (adequação do documento em questão aos objetivos do estudo), considerou-se a amostra extraída das respostas dos 19 assistentes sociais lotados no sistema penitenciário do Rio de Janeiro, constituindo assim o corpo do trabalho a ser tratado e interpretado.

Parte significativa da pré-análise dos dados foi realizada pelo CRESS/RJ: a coleta de dados, como fora informado, e a transcrição das respostas ${ }^{2}$. Desta forma, o CRESS/RJ garantiu os critérios de homogeneidade (na medida em que os dados obtidos usaram técnicas semelhantes) e exaustividade (porque não omitiu nenhum dado prestado pelos participantes no momento da transcrição).

Houve um pouco de dificuldade com o acesso ao material, que foi entregue a bibliotecária do CRESS em meados de 2018, para que ela realizasse a indexação na biblioteca do conselho.

Em posse do documento final e iniciada a pré-análise, foram percebidos alguns detalhes que poderiam dificultar a análise documental, como respostas muito fragmentada (citação apenas de um ou dois termos ou frases muito curtas), apesar de o questionário ser de respostas abertas, abreviações de termos muito específicos da área e escassez de dados e informações para traçar o perfil desses profissionais.

Em relação à primeira dificuldade (respostas muito fragmentada), não houve o que ser feito, tendo que trabalhar com o material disponível, visto que em

\footnotetext{
${ }^{2}$ Em CRESS/RJ (2018), o processo de análise documental foi realizado sob o olhar do materialismo histórico-dialético. Entretanto, as temáticas que foram extraídas diziam respeito a todo o campo sócio-jurídico. Como o interesse da presente pesquisa era o campo do sistema prisional, não se utilizou as demais etapas no processo, restringindo-se a coleta e a transcrição (ainda na fase de pré-análise). Essa parte do trabalho é sem dúvida muito exaustiva e fortaleceu o sigilo das fontes pesquisadas (assistentes sociais, estagiários e outros participantes).
} 
tempos democráticos a realização de pesquisas na SEAP costuma ter autorização demorada, quiçá em período de Intervenção Federal no Estado do Rio de Janeiro.

Já a segunda dificuldade pôde-se escrever por extenso as abreviações. Nesse processo, a empiria acumulada de dois anos de estágio supervisionado no Instituto Penal Vicente Piragibe, entre 2014 e 2016, foi fundamental para reconhecer e compreender o contexto e os próprios termos em si abreviados. Com isso, nos fragmentos citados ao longo da análise proposta não aparecerão abreviações.

A terceira dificuldade relacionada ao perfil dos profissionais e a escassez de dados de identificação tentou-se suaviza-la com um cruzamento de dados entre o quantitativo de questionários respondidos e a assinatura da lista de presença. Nesse processo, assim como os questionários considerados foram apenas os assinalados como "profissionais da SEAP", considerou-se na lista de presença também a mesma sinalização.

Com isso, puderam-se apreender algumas tendências no perfil profissional. Por que não se trata exatamente do perfil profissional? Nos questionários não existia nenhum campo de identificação. Essas informações foram extraídas, como supracitado, da lista de presença com a sinalização do campo "profissional da SEAP”. Assim, conseguiu-se apenas registrar a composição por sexo, considerando 17 dos 19 profissionais da SEAP participantes da pesquisa; e a faixa etária, que considerou 15 dos 19 profissionais, conforme gráfico I.

GRÁFICO I - PERFIL PROFISSIONAL POR SEXO E FAIXA ETÁRIA.

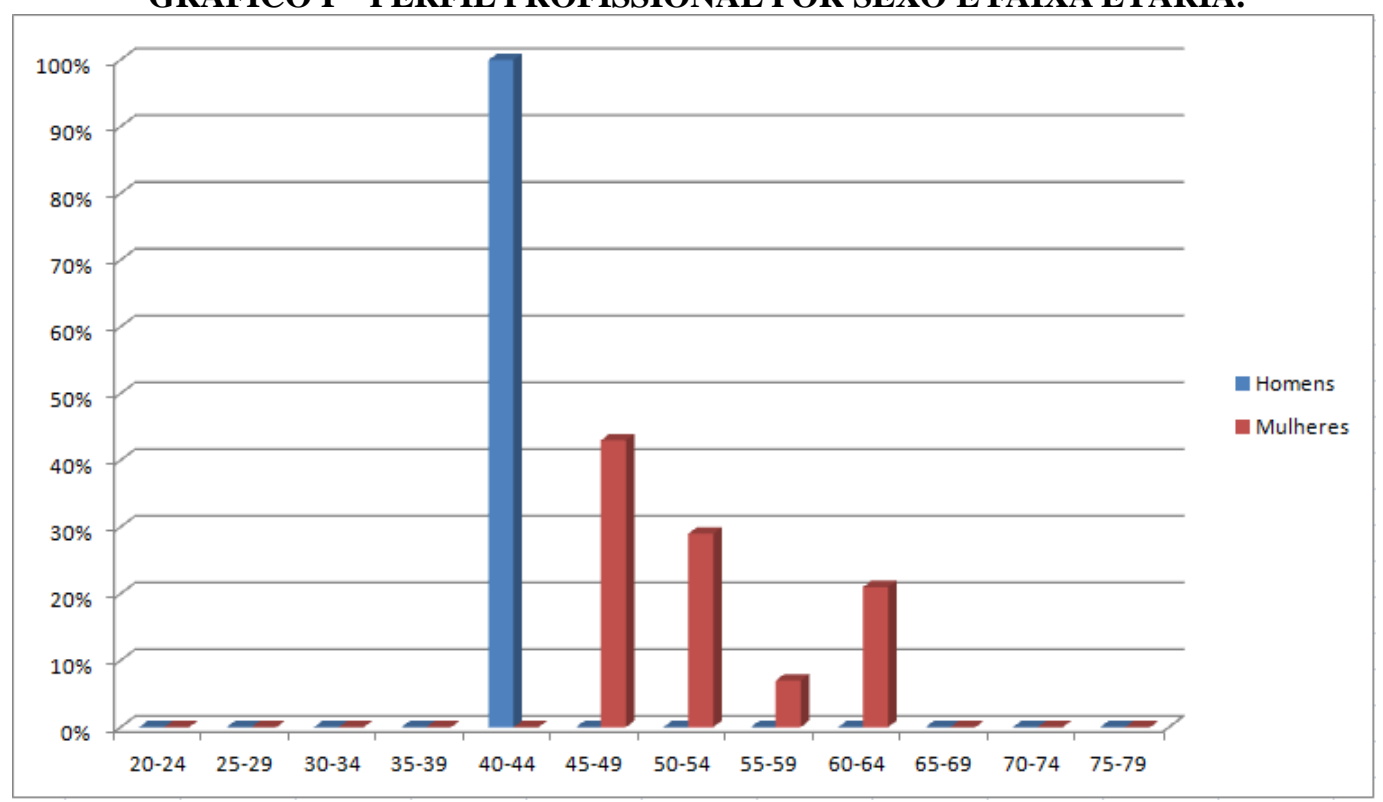

FONTE: Apêndice de CRESS (2018). Compilação Própria. 
A resposta escrita pelo profissional em cada eixo do questionário foi agrupada por temas. Desta forma, registraram-se os temas a seguir, de acordo com os eixos temáticos:

- Demandas: demandante; demanda;

- Respostas profissionais: ações burocráticas; ações profissionais; conhecimento; instrumentos e técnicas;

- Dificuldades: condições de trabalho; correlação de forças; subalternidade da profissão;

- Violação de direitos: agente violado; arbítrio; inobservância da lei; privação de serviços;

- Possibilidades de trabalho: articulação intraprofissional; articulação política; e rede socioassistencial.

Sistematizados os temas, realizaram-se as interpretações com base na pesquisa bibliográfica. 


\section{PARA ALÉM DAS PRISÕES: sociedade capitalista e prisões.}

Uma primeira aproximação sobre a população carcerária nos faz perceber que são pessoas, geralmente homens, de nível educacional baixo e com falta de profissionalização (OLIVEIRA, 2016, p. 245-246) as que estão historicamente reclusas nas prisões em todo o mundo. No Brasil, dados do Ministério da Justiça e Segurança Pública (2017, p. 33) reforçam a tese: em 2016, 75\% da população carcerária brasileira tinham até o ensino fundamental completo - portanto, um indicador social de pobreza.

Uma indagação surge dessa aparência: seria a pobreza o elemento determinante para a criminalidade? Em 1859, Marx ([1859] 2015, p. 120) comparou os dados do crescimento populacional, da criminalidade e acerca do pauperismo no Reino Unido, entre 1844 e 1858. Os resultados encontrados foram por ele sintetizados:

\footnotetext{
"Ao comparar as três tabelas populacionais, de criminalidade e acerca do pauperismo (pauperism), encontraremos: durante o período de 1844 a 1854 a criminalidade cresceu em nível mais acelerado do que a população, enquanto a pobreza (pauperism) permaneceu praticamente inalterada entre 1849 e 1858, apesar das enormes mudanças operadas neste intervalo no estado da sociedade britânica".
}

Marx ([1859] 2015, p. 120) denuncia que o período analisado correspondeu à expansão do mercado mundial com duplicação ou triplicação de seu poder de absorção, caracterizando o período como decênio memorável. E, assim, ele sintetiza a análise: “deve haver algo de podre na essência mesma de um sistema social que eleva sua riqueza sem diminuir sua miséria, e eleva sua criminalidade ainda mais rapidamente" (MARX, [1859] 2015, p. 120).

Assim posto, acredita-se que a indagação supracitada deva ser reorganizada para "quais processos sociais são determinantes para a punição?" e “quais as funcionalidades das punições ao capital?”. Inverte-se a perspectiva analítica: ao invés de analisar a criminalidade como desdobramento causal da pobreza, pensa-se nas punições como expressões de um modo de produção econômico e social.

Punições essas destinadas não a todo segmento da sociedade, mas a um público genuinamente alvo de controle: a população economicamente alijada dos processos legais de trabalho. Sob a perspectiva histórica, assim, busca-se responder às indagações suscitadas. É na gênese do capitalismo que se encontra a 
base material para compreender alguns fenômenos sociais que possuem rupturas, continuidades e reatualizações históricas.

\subsection{As bases históricas da população destinada às prisões: acumulação primitiva e superpopulação relativa.}

Para Marx (1985), a marca genética, o DNA do sociometabolismo do capital são o sangue e a sujeira. Transformar produtores em assalariados não pode ocorrer senão pela marca da violência. Deste modo, debruçado para apreender a gênese do capitalismo, Marx discorre que nos anais da humanidade a libertação da servidão e da coerção corporativa, próprias do modo de produção feudal, foi inscrita a sangue e fogo: a usurpação das terras comuns e a expulsão dos camponeses; a limpeza das propriedades (varrer delas os seres humanos); as demolições ou o abandono à decadência das habitações ou choupanas dos produtores; o êxodo rural compulsório e súbito; o furto aos bens da Coroa e o saque aos bens da Igreja; o roubo e a escravização de seres humanos - ora dissimulado, ora sem escrúpulo, inclusive de crianças; o endividamento estatal (a dívida pública, base oculta da rapinagem); e a tributação excessiva com centralidade sobre os meios de subsistência constituem os vetores propulsores de transição do antigo modo de produção para o moderno.

A alvorada do capital, portanto, se constitui por via do emprego da persuasão e da violência com suporte estatal. Uma legislação sanguinária, um grotesco terrorismo legalizado à base do açoite, do ferro em brasa e da tortura foi responsável por disciplinar os produtores expropriados, "bruscamente arrancados das suas condições habituais de existência" (MARX, 1985, 851), às novas requisições que lhes eram impostas. Em síntese, comprimir salários (proibição de pagamentos acima do salário máximo), impedir a organização ou associação dos produtores expropriados, prolongar a jornada de trabalho e disciplinar à força de trabalho nascente era o papel desempenhado pela força do Estado para garantir a produção de mais-valia de forma conveniente à burguesia nascente ${ }^{3}$.

Percebe-se que o selo de garantia do capital, enquanto existir, é a expropriação intermitente e violenta. Forja-se, com isso, um quadro de produtores expropriados "que por educação, tradição e costume aceita as exigências daquele

\footnotetext{
${ }^{3}$ Uma determinada lei "autorizava o patrão a recorrer à coação física para obter o trabalho de acordo com a tarifa legal" (MARX, 1985, p. 856).
} 
modo de produção como "leis naturais evidentes"” (MARX, 1985, p. 854). A produção de uma superpopulação relativa, a coação surda das relações econômicas e a estrutura totalizadora do capital de comando político ${ }^{4}$ à época quebraram toda resistência.

As leis econômicas são ainda mais cruéis. A receita pública cria um ciclo de recorrer a empréstimos para despesas extraordinárias, aumentar impostos para pagar tais empréstimos e contrair novos empréstimos para novas despesas. Condena-se, com isso, à "eternidade" o julgo do trabalho ao capital e a subordinação de numerosos países a alguns países. Para Marx (1985), a dívida pública e o correlato sistema tributário são partes constituintes da acumulação primitiva, cuja eficácia expropriante é inegável ${ }^{5}$.

Em tela, apreende-se que longe de ser um processo repentino, curto, sereno e idílico, a transição do modo de produção feudal para o capitalista foi secular e violenta. Deriva da sociedade feudal, portanto, as bases materiais para a sociedade do capital. A chamada "acumulação primitiva é apenas o processo histórico que dissocia o trabalhador dos meios de produção" (MARX, 1985, p. 830). Nega-se, a partir da história, a economia política clássica que creditava ao pecado original a "natural" exploração ${ }^{6}$. Compreende-se, assim, que "a força é a parteira de toda sociedade velha que traz uma nova em suas entranhas. Ela mesma é uma potência econômica” (MARX, 1985, p. 869).

Esse processo violento de expropriação e separação dos produtores dos meios de produção - a gênese do modo de produção capitalista - é a base material da simplificação dos antagonismos de classes. É o processo que constituiu dois campos hostis: a classe burguesa e classe trabalhadora (MARX e ENGELS, 2003, p. 27).

É a inserção no processo de produção que determina em qual classe o sujeito pertence: os que foram expropriados da base fundiária e dos meios de

\footnotetext{
${ }^{4}$ Para Mészáros (2011), o Estado é a estrutura totalizadora do capital de comando político.

5 "Na Holanda onde se implantou esse regime pela primeira vez, o grande patriota de Witt lovou-o em suas máximas, proclamando-o o melhor sistema para manter o assalariado submisso, frugal, ativo e... sobrecarregado de trabalho" (MARX, 1985, p. 874).

${ }^{6}$ A economia-política clássica tem comparado este processo ao pecado original. Para ela, provem do afrontamento a determinação divina, realizado por Adão e Eva, a separação de duas espécies de gente: uma parcela laboriosa e inteligente e a outra preguiçosa e vadia, cuja a primeira se constituiu a elite econômica e a segunda a plebe e a escória. Esta tese explicaria a identidade entre riqueza nacional e pobreza do povo se não fosse ela própria uma negação da história concreta, como demonstrou Karl Marx no capítulo estudado d'O Capital.
} 
produção necessários à reprodução da vida material e, assim, lançados ao mercado de trabalho e os que súbita e violentamente tomaram para si os meios de produção, ambos se confrontam no mercado de trabalho como detentores de mercadorias distintas entre si: muitos apenas com a sua força de trabalho disponível para troca, colocando-a para produzir riqueza a outrem e valorizar capital e poucos aparentemente donos dos meios de produção, os quais tomarão para si a riqueza socialmente construída, os primeiros trabalhadores e os segundos burgueses (MARX, 1996b).

Ademais, o capital - enquanto relação social entre trabalhadores e burgueses que emerge do processo de produção e se espraia para toda a dinâmica das relações sociais - varia sua quantidade de trabalhadores diretamente inseridos nos processos produtivos conforme suas necessidades e interesses de valorização, o que influenciará no destino da classe trabalhadora. Essa relação quantitativa e proporcional entre capital (seja na sua dimensão de valor do meio de produção ou montante do próprio meio de produção - capital constante) e força de trabalho (seja na sua expressão de soma global de salários ou montante da própria força de trabalho - capital variável) é denominada de composição orgânica do capital (MARX, 1996b, p. 245).

Segundo Marx (1996b, p. 260), a constante metamorfose que perpassa a produção capitalista e suas implicações na composição orgânica do capital infere em uma alteração na proporção entre o capital constante e o capital variável. Originariamente, a proporção era 1:1, mas ao crescer o capital altera-se para 1:2 de capital constante (progressivamente $2: 3 ; 3: 4 ; 4: 5 \ldots$ ) e $1: 2$ de capital variável (progressivamente 1:3, 1:4; 1:5...). Ou seja, o desenvolvimento capitalista carrega consigo intrinsecamente a substituição da força de trabalho (capital variável) pelo meio de produção (capital constante), expulsando progressivamente trabalhadores do processo produtivo.

Esta força de trabalho expulsa do processo de produção conformará a superpopulação relativa ou o exército industrial da reserva (manter os níveis de produção ou mesmo intensificá-lo com quantidade cada vez menor de força de trabalho $^{7}$ é a regra do modo de produção capitalista, assim como a apropriação

\footnotetext{
${ }^{7}$ Ainda que em pouca quantidade, a força de trabalho do trabalhador (trabalho vivo) é indispensável, somente ele é capaz de produzir valor. Tanto o é que em determinadas condições
} 
privada da riqueza ali produzida, que aumenta na mesma proporção que o pauperismo - refere-se à lei geral de acumulação capitalista).

Para Marx (1996b), a superpopulação relativa - uma condição da existência do capitalismo - varia em líquida (ou flutuante), latente e estagnada. Oliveira (2010, p. 279) sintetiza os conceitos:

\begin{abstract}
A primeira delas ele chama de flutuante. Nessa forma, o número de trabalhadores das fábricas, manufaturas, usinas siderúrgicas e minas podem aumentar ou diminuir, aumentando o número de empregados, porém não na mesma razão do aumento da produção. A outra forma seria a constante migração do campo para a cidade, principalmente quando a agricultura introduz técnicas capitalistas e expulsa milhares de trabalhadores rurais que, por não encontrarem postos de trabalho na agricultura, voltam-se para as cidades em busca de oportunidade de trabalho, formando um excedente de trabalhadores também na área rural. Por último, tem-se a forma estagnada da superpopulação relativa representada pelos trabalhadores irregulares, cuja ocupação não se insere nem na grande indústria, nem na agricultura. São os trabalhadores supérfluos, precários e temporários, mas que contribuem para a lógica da acumulação, pois pressionam o contingente de trabalhadores excedentes para cima. A superpopulação relativa estagnada divide-se em três grupos, os aptos para o trabalho, os filhos e órfãos dos indigentes e os incapazes para o trabalho. É nesta fração da classe trabalhadora que se expande com maior rapidez a pauperização e a miséria.
\end{abstract}

Todo esse processo de separação entre produção e seu controle (dos meios de produção e dos produtos do trabalho) e a constituição e a administração da superpopulação relativa ocorreu - e se perpetua - com a mediação de uma estrutura de comando político: o Estado, cuja emergência se baseia materialmente no caráter inconciliável das contradições das classes sociais (LENIN, 2007, p. 27).

Nas palavras de Lênin (2007, p. 27), "para Marx, o Estado é um órgão de dominação de classe, um órgão de submissão de uma classe por outra; é a criação de uma 'ordem' que legalize e consolide essa submissão, amortecendo a colisão das classes". Portanto, o poder político organizado sob o controle das classes dominantes: na sociedade capitalista, os burgueses.

O Estado enquanto tal existe na mesma razão que se perpetua as classes sociais, isto é, representa o processo de reprodução social das classes sociais. E para se legitimar necessita aparentar ser uma "força pública". "Engels desenvolve a noção de 'força' que se chama Estado, força proveniente da sociedade, mas superior a ela e que dela se afasta cada vez mais. Em que consiste pouco mais de capital variável para expandir sua acumulação e valorização. 
fundamentalmente essa força? Em destacamentos especiais de homens armados tendo à disposição prisões etc" (LÊNIN, 2007, p. 29).

Assim, quanto mais se agudizam as contradições de classes (como a intensificação do desemprego e sua relação direta com o aumento da superpopulação relativa), mais o Estado se afirma como "força pública" (PANIAGO, 2012, p. 13).

Essa "força pública", que tem a sua disposição as prisões, dentre outros elementos (como destacamento de homens armados), como legítimo e legitimante, de sua existência exerce seu poder de controle de forma organizada sobre a classe trabalhadora, em especial na superpopulação relativa. Entretanto, a função de controle das prisões não é a única por ela desenvolvida.

\subsection{Funcionalidades das prisões ao capital.}

Uma observação inicial se mostra conveniente quando se propõe abordar as funções das prisões no âmbito dos Programas de Pós-Graduação em Serviço Social (PPGSS) ${ }^{8}$. Não se pretende resgatar a perspectiva modernizadora do período de renovação profissional ${ }^{9}$ que se baseou teoricamente pelo estrutural-

\footnotetext{
${ }^{8}$ O presente estudo é uma dissertação elaborada no Programa de Pós-graduação em Serviço Social da Pontifícia Universidade Católica do Rio de Janeiro (PUC Rio), sob a orientação da assistente social Ariane Rego de Paiva. O Serviço Social é uma especialização do trabalho coletivo que emerge no período clássico do imperialismo para operar uma dupla dinâmica contraditória: ao operacionalizar (e anos mais tarde também planejar e gerir) as políticas sociais, incide nas relações sociais entre capital e trabalho, sendo a profissão demandada por ambas as classes sociais fundamentais no processo de reprodução social.

${ }^{9}$ Uma síntese de Netto (2004, p. 120-240) contextualiza o processo de renovação profissional: Em nível de América Latina, mudanças nos espaços ocupacionais desdobram-se em novas exigências à profissão. Ao tentar equacionar as questões emergentes, segmentos da profissão percebem a necessidade de se romper com a funcionalidade da profissão à ideia de superação do subdesenvolvimento continental e, com isso, questionam o próprio trabalho profissional e suas vinculações teóricas e políticas então em voga. Esse processo instaura uma crise no chamado Serviço Social tradicional - historicamente vinculado à Igreja, sob bases filosóficas tomista - e constitui o início da articulação do Movimento de Reconceituação do Serviço Social, uma espécie de grande união para reconceituar a profissão continentalmente. Em nível de Brasil, sob influência do Movimento de Reconceituação e tendo por base material as alterações e consolidação do mercado de trabalho ao assistente social e a inscrição do Serviço Social no espaço universitário assim como as legislações que regulamentaram a profissão e constituíram seus nortes éticos e políticos -, houve um processo de renovação que desdobrou-se em uma guerra de movimento em torno do significado sócio-histórico da profissão e dos compromissos político assumidos ou velados. Três foram as perspectivas que participaram da disputa: (i) a perspectiva modernizadora, caracterizada por (a) reatualizar o tradicional (caso, grupo e comunidade), mas sob base do estrutural-funcionalismo; (b) manter inalterada a percepção da profissão sobre a realidade social (permanência da a-historicidade e acrítica à sociopolítica); (c) (re)introduzir o metodologismo, mas sob base da macroatuação; (ii) a perspectiva de reatualização do conservadorismo, marcada pela/o (a) defesa da fenomenologia; (b) resgate da ética-cristã; (c) atuação focada no indivíduo para integra-lo à sociedade, que aparece como imutável; e (iii) a perspectiva de intenção de
} 
funcionalismo norte-americano (NETTO, 2004). Esta perspectiva atrelada à modernização conservadora no período da autocracia burguesa e seu conteúdo reformista são incompatíveis com as vertentes profissionais críticas e mesmo tradicionais no Serviço Social brasileiro que disputavam com maior fôlego a hegemonia da direção social e política entre as décadas de 1960 e $1980^{10}$.

Tampouco se propõe retomar a teoria estrutural-funcionalista do desvio e da anomia. Para Baratta (2016, p. 59-60), a criminologia funcionalista compreende o desvio - ou o delito - como fenômeno normal de toda estrutura social, sendo fator útil e necessário para o equilíbrio e o desenvolvimento sociocultural. Portanto, elemento funcional. Entretanto, perde seu valor positivo apenas quando ultrapassa determinados limites, como o crescimento excessivo do desvio (a anomia). Nega-se, desta forma, o princípio do bem e do mal. Baratta (2016, p. 59) considera que a teoria funcionalista representou uma virada sociológica na criminologia contemporânea, constituindo-se como "a primeira alternativa clássica à concepção dos caracteres diferenciais biopsicológicos do delinquente e, por consequência, à variante positivista do princípio do bem e do mal" 11.

Serra (2007, p. 204) propõe uma distinção epistemológica e política entre a análise funcional e o funcionalismo. $\mathrm{Na}$ medida em que a perspectiva funcionalista visa compreender a sociedade como aspectos integrados, percebendo as instituições - assim como as ações e os próprios seres sociais - como funcionais ou disfuncionais, ou seja, atrelada a uma dimensão positiva da sociedade (portanto, imutável), a análise funcional pode suscitar aproximações sucessivas com a realidade concreta das instituições, apreendendo "como a sociedade não funciona ou como ela funciona negativamente", ou seja, perceber repercussões negativas que engendram o próprio movimento contraditório da realidade. Tais contradições sociais possibilitam, inclusive, o questionamento e a proposição de superação da ordem social que vigora. Serra (2007, p. 204) defende

ruptura, que se hegemonizou como direção social e política da profissão. Sua distinção em relação às demais é a presença de uma crítica radical à estrutura da sociedade burguesa e à subordinação funcional do Serviço Social ao capital.

10 Netto (1996) considera a vertente teórico-profissional modernizadora ainda em condições de disputa. Porém defende-se aqui que com menores condições objetivas de, hoje, enfrentar a perspectiva de intenção de ruptura, que construiu o projeto ético-político profissional, desde o Congresso da Virada, em 1979.

11 Esta tese se contrapõe, inclusive, ao jusnaturalismo e seu dualismo indivíduo-sociedade, em que a sociedade reprime a liberdade e o poder arbitrário do indivíduo (BARATTA, 2016). 
que uma análise funcional consensual na criminologia crítica é a reflexão de que o sistema penitenciário exerce a função de controle social.

Salvaguardada estas observações iniciais, acredita-se que compreender as funções exercidas pelo sistema prisional na contemporaneidade pode melhor ilustrar a matéria a que se debruça o trabalho profissional de assistentes sociais na referida instituição. Se forem consensuais na literatura crítica do Serviço Social que o objeto de trabalho do assistente social são as expressões da "questão social", o reconhecimento deste objeto no sistema prisional ainda é nebuloso, difuso e confuso para a categoria que ali atua cotidianamente.

Uma tese coerente é a de Pereira (2010) que considera a custódia como objeto de trabalho do assistente social nas prisões. Esta tese, porém, restringe-se a concepção da função das prisões a sua dimensão política de controle social. Necessita, portanto, de atualização dialética, visto a mutação e complexidade constante da sociedade e, por conseguinte, das penas e das prisões.

Desta forma, constrói-se a argumentação teórica a partir da perspectiva de superar um aparente paradoxo penal: situar o sistema prisional como processo social articulado à totalidade concreta nos parece ser o caminho para desvelar os fins assumidos (os chamados discursos oficiais) e aqueles (nem tão) dissimulados (assim) que são efetivamente realizados (compreendendo, inclusive, a matéria profissional requisitada ao assistente social).

O discurso oficial, ou nos termos de Serra (2007) as teorias da pena, que atribui legitimidade às prisões são as de suas funções sociais de retribuição e prevenção (especial e geral) - inclusos os ideais de restauração (ou reformas). Elas correspondem à suposta finalidade atribuída às prisões pelo direito penal (RUSCHE e KIRCHHEIMER, 2004).

A retribuição é o sentido de justiça atribuído à pena. Não há nenhuma perspectiva finalística que não seja a ideia abstrata de justiça. Trata-se meramente de compensar em termos quantitativo o crime praticado, embora qualitativamente sejam distintos (SERRA, 2007, p. 207). Em outros termos, é a pena com um fim em si mesma. E quaisquer outros objetivos são efeitos desprezíveis.

A constituição histórica da retribuição como teoria da pena corresponde ao período de acumulação primitiva. Para Serra (2007, p. 208), a destruição da força de trabalho, no período assim chamado de acumulação primitiva, derivaria de 
duas medidas: a primeira pela sua abundância e a segunda da percepção do sujeito como ser racional e, portanto, digno de punição equivalente ao delito praticado.

Por outro lado, conceber a pena como prevenção especial exprime uma finalidade oposta à teoria da retribuição, embora permaneça situada no âmbito do indivíduo. Ela situa a pena como meio para alcançar um determinado fim (SERRA, 2007, p. 208). Para Serra (2007, p. 208-209), a prevenção especial, assim, teria um duplo sentido: o negativo e o positivo. Enquanto o primeiro se relacionaria à pretensão de neutralizar o sujeito com a privação de sua liberdade, $o$ segundo estaria vinculado à ideia de transformá-lo, corrigi-lo, isto é, reformá-lo. Esta reforma relaciona pena e tratamento; privação de liberdade e cura; e compreende o crime como patologia. Requisita, inclusive, profissionais das Ciências Sociais (SERRA, 2007, p. 210) - dentre os quais se podem citar, na contemporaneidade, o assistente social - para operar a reforma moral, a partir da classificação dos "desviantes" segundo critérios individualizadores da pena e, por consequência, o tratamento adequado: prevenção especial negativa ou prevenção especial positiva.

A processualidade histórica, em que se desenvolve a teoria das penas preventivas especiais, tem no questionamento do Estado liberal sua raiz. De acordo com Serra (2007, p. 210), o advento da teoria das penas preventivas especiais corresponde a defesa da ampliação interventiva do Estado. Assim, parece-nos que ela - a prevenção especial - é correlata com a emergência das políticas públicas, portanto no estágio superior do capitalismo.

Por outro lado, conforme Serra (2007, p. 211), a prevenção geral se direciona a sociedade em geral. Sua capacidade teleológica exprime, em suma, um duplo dinamismo: o negativo, que se trata da intimidação e dissuasão à sociedade para que ela não realize práticas ilícitas, isto é, de caráter psicológico, uma antecipação à consumação, e o positivo, que busca validar o direito penal frente a infração, ou em outros termos, além de reação, a pena seria o reforço da autoridade da norma jurídica - pressupondo, inclusive, a necessidade de o crime persistir, pois este seria funcional à ordem social, esta perspectiva deriva do estrutural-funcionalismo (BARATTA, 2016).

Percebe-se que as funções manifestas da pena se calcam no utilitarismo e na racionalidade formal-abstrata, típicas formas de pensamento que se desenvolvem em concomitância à sociedade capitalista. Tais discursos servem 
para legitimar o poder punitivo do Estado, reforçar a ordem social vigente e reduzir a pena à privação de liberdade, que tem no cárcere seu espaço de realização, como suposto mecanismo de segurança.

O deslocamento da punição corporal à privação de liberdade tem na necessidade econômica, no valor simbólico da liberdade e do tempo na sociedade capitalista e nos desdobramentos políticos e ideológicos sua explicação. Assim, a instituição-prisão tem funções (nem tão) dissimuladas que precisam ser (melhor) desveladas e didaticamente expostas. É o que se pretende a seguir.

\subsubsection{As reais funções das prisões no sistema capitalista.}

Este aparente paradoxo penal - discurso oficial falacioso e funcionalidade real - desdobra-se em uma crise de legitimidade do sistema penal. A crise do discurso oficial, sob bases supostamente científicas, permite uma relegitimação do sistema penal ainda mais perigosa.

Andrade (2012, p. 284-287) credita tal crise a elementos que permeiam todo o sistema penal: a moralidade maniqueísta (bem $x$ mal), a visão expiatória da pena como castigo pelo dano, a relação adversarial, a 'eficácia invertida' do sistema penal, a construção seletiva da criminalidade, a fabricação de criminosos, a sua conformação genuinamente dirigida à violação de direitos e à violência, a sua ilusão de segurança jurídica, a sua contribuição na reprodução das desigualdades, aos seus elevados custos, a vitimação e baixa valorização de seus próprios trabalhadores (policiais e agentes penitenciários), a extensão da pena aos familiares, ao seu caráter de imputação de responsabilidade individual (em detrimento da solução de conflitos, portanto sem apresentar qualquer efeito positivo à vítima), a dificuldade de manter sob controle e, por fim, o próprio sistema se apresentar como problema público.

Recorre-se, assim, as funções (nem tão) latentes (assim) da prisão, ultrapassadas o véu da aparência e desvelada seu assentamento na base material de uma sociedade polarizada em interesses antagônicos de classes sociais (SERRA, 2007, 203).

Portanto, diverge-se do discurso oficial que relaciona simetricamente crime e castigo; delito e pena, atribuindo outras funções à prisão que são mais 
complexas e efetivas na realidade concreta - e nos termos de Rusche e Kirchheimer (2004, p. 19), sem negar que a pena tenha fins específicos.

Dissociar crime e castigo permite vislumbrar as funções (nem tão) dissimuladas (assim) do sistema prisional. Romper com essa aparente sintonia, para Rusche e Kirchheimer (2004, p. 19), permite apreender as verdadeiras relações que dão significado à pena. Enquanto tal, a pena inexiste. Ela não pode ser explicada exclusivamente sob o ponto de vista religioso, moral ou meramente jurídico e seus supostos fins sociais (RUSCHE e KIRCHHEIMER, 2004, p. 19) acima descritos como discursos oficiais - como mecanismos de combate à criminalidade.

Segundo Rusche e Kirchheirmer (2004, p. 19-21), a prática penal é a manifestação de um modo de desenvolvimento específico, em que o desaparecimento do segundo implica na inaplicabilidade da primeira (ainda que possa coexistir práticas punitivas de períodos históricos distintos, a prática penal por excelência é determinada e se sobrepõe a qualquer outra). Defende-se, assim, a funcionalidade do sistema prisional ao capital como econômica, política e ideológica (RUIZ, 2016).

Segundo Ruiz (2016), o viés econômico da funcionalidade ao capital das prisões estaria associado a oferta de serviços, terceirizações, privatizações e indústria de segurança privada. Nos termos de Reishoffer e Bicalho (2015, p. 21), “a privatização carcerária [propicia] um mercado emergente para toda uma rede de serviços de vigilância, alimentos, seguro, serviços, administração, manutenção, arquitetura, financiamento, construção, transporte". Percebe-se uma defesa dirigida às esferas do consumo e da circulação de mercadorias.

A tese do complexo industrial-prisional de Davis (2018) indica um caminho de alcançar as esferas da produção. Ela se sustenta na defesa que as empresas vislumbram o preso como matéria prima em uma tríade: (i) a servidão penal - força de trabalho mal remunerada; (ii) uma massa de consumidores; e (iii) a retenção elevada da custódia. Portanto, as prisões são fontes potenciais de lucro - e em certa medida de produção de mais-valia.

Para Davis (2018), a partir da realidade estadounidense, o complexo industrial-prisional são estruturas e ideologias que ampliam o poder do racismo e da xenofobia, associados a reestruturação do capital e a busca pelo lucro por via, fundamentalmente, da construção e gestão de presídios e da superexploração do 
trabalho de presos (servidão penal). Pressupõe uma relação simbiótica (e não de oposição) com o complexo industrial-militar a partir da destruição social (parafernálias tecnológicas para controle territorial e penal e eliminação dos negros e imigrantes, em geral pobres).

Esse complexo exige padrões privatizantes nas políticas públicas e, por consequência, na política penal. Um empreendimento lucrativo que tende, por sua vez, a defesa da extensão do tempo de pena, enquanto suposta forma de combate à criminalidade.

\footnotetext{
"Em arranjos que lembram o sistema de arrendamento de condenados, os governos federal e estadual e os governos dos condados pagam às empresas privadas uma taxa por preso, o que significa que essas empresas privadas têm interesse em reter os detentos na prisão por maior tempo possível e em manter suas instalações cheias" (DAVIS, 2018, p. 103)
}

Davis (2018), inclusive, resgata a relação com a indústria médicafarmacêutica, em que os presos historicamente serviram de cobaias para pesquisas médicas - "posicionando assim a prisão como um elo importante entre universidades e empresas".

Outra função econômica da prisão associa-se às influências no mercado de trabalho, como "complemento indispensável à imposição de ofertas de trabalho precárias e mal remuneradas" (WACQUANT, 2008, p. 11 - grifos originais). Outrora reguladora do preço da força de trabalho no mercado livre (SOUZA, 2015), para Wacquant (2008), hoje essa influência tem uma dupla dinâmica. Ele defende (i) que as prisões influencia diretamente - e melhor do que a legislação trabalhista - a regulamentação dos nichos mais precários do mercado de trabalho; e (ii) movimenta todo um aparato que reduz artificialmente a taxa de desemprego (aumenta empregos diretos com as forças de trabalho dirigidas à retenção e custódia; impulsiona empregos indiretos, nos serviços carcerários e produtos; e retira parcelas da população das estatísticas de desemprego - os presos não são contabilizados como desempregados) e "fluidifica" os empregos mal remunerados. Nos termos de Wacquant (2008, p. 13), "ex-detentos dificilmente podem exigir algo melhor que um emprego degradante e degradado em razão das trajetórias interrompidas, dos laços sociais esgarçados, do status jurídico ignominioso e do amplo leque de restrições legais e obrigações civis implicadas". 
Ainda em relação às incidências sobre o mercado de trabalho, têm-se as assertivas de Baratta (2016). Conforme o autor (2016, p. 167), os efeitos da população criminal influem na dinâmica convencional do mercado de trabalho, como a superexploração dos egressos e a participação no rebaixamento dos salários (efeito da concorrência), e para além dela: "pense-se no emprego da população criminal nos mecanismos de circulação ilegal do capital, como peão na indústria do crime, no ciclo da droga, etc."

Por sua vez, a funcionalidade política - estritamente vinculada à dimensão econômica - é a forma estatal de lidar com a superpopulação relativa. Para Amaral (2016, p. 53), um traço persistente da prisão é o uso privilegiado dela para conter as assimetrias sociais derivadas do modo de produção. Na medida em que a pobreza crescia na razão direta em que aumentava a capacidade social de produzir riquezas (NETTO, 2007, p. 154), os efeitos corolários e necessários para o desenvolvimento capitalista se desdobraram em contradições sociais que reconfiguram o ambiente sócio-político: os trabalhadores expropriados violentamente dos meios de produção reagiram de formas distintas. Emerge-se a necessidade de discipliná-los à nova lógica de trabalho (a subsunção do trabalho ao capital, a apropriação privada da riqueza social) e de legitimar o papel punitivo do Estado (BARATTA, 2016).

Consolidada a sociedade burguesa, a disciplina permanece necessária frente a "racionalização" dos processos produtivos, na atual lógica de desenvolvimento (BARATTA, 2016, p. 195), mas não corresponde mais àquela de outrora. A prisão cumpre, assim, a função política de conter a tensão originária do conflito entre o capital e trabalho, prioritariamente na fração da classe trabalhadora marginalizada, a superpopulação relativa.

Ou seja, outrora utilizada para produzir sujeitos dóceis e úteis (FOUCAULT, 2014) - que era uma exigência das relações de produção (BARATTA, 2016, p. 195), as prisões atualmente são especializadas em controlar e administrar os "grupos que se tornaram supérfluos ou incongruentes pela dupla reestruturação da relação social e da caridade do Estado: as frações decadentes da classe operária e os negros pobres" (WACQUANT, 2011, p. 104).

Para Oliveira (2016, p. 243-269), a organização da esfera produtiva nos ditames do capital exige certa flutuação de demanda por força de trabalho (relevância quantitativa da população para a produção), que, no âmbito da política 
penal, se desdobra na natureza da pena e na sua duração. Ele projeta, assim, quatro paradigmas punitivos de controle do Estado sobre a superpopulação relativa:

- Paradigma da mutilação: com a quebra dos vínculos sociais em torno do processo de produção, - a expulsão da vida agrária, o impedimento militar de retornar a ela (refere-se a privatização das terras, a criação da propriedade privada capitalista) e a pouca absorção pela manufatura incipiente, segmentos da população tornam-se economicamente supérfluo, sobrante. Esta população torna-se, em especial, mas não exclusivamente, preocupação estatal. Como recurso político-administrativo, desenvolve-se uma política penal para lidar com essa população supérflua. No entendimento em que elas não retornariam ao trabalho, seus corpos poderiam ser mutilados ou mesmo destruídos (mutilações, açoites e extermínio pela forca,).

- Paradigma do encarceramento: a diminuição do crescimento demográfico, a expansão da manufatura e o esforço de colonização foram elementos percebidos pela economia que acarretou na mudança do paradigma de política penal. Ultrapasse-se a destruição daquela população, admite-se a escassez populacional e emprega-se forçosamente a população desviante como força de trabalho escrava. Condena-se à galés e às casas de correção. A transformação das casas de correções nas modernas prisões, enquanto armazém de gente, tem na relevância econômica da população sua explicação. A capacidade de a população ser contratada e demitida conforme as exigências do mercado inflexiona a política penal para abandonar a utilização do trabalho prisional. Em síntese, com ou sem trabalho prisional, a prisão se torna o depósito da superpopulação relativa. Ela se institucionaliza como pena por excelência da sociedade moderna.

- Paradigma das penas alternativas: frente a uma demanda crescente de força de trabalho, aprimora-se a ciência penal. Emerge as penas alternativas, as progressões de regimes e novas especializações judiciais que vão migrar determinados assuntos da esfera criminal para a esfera administrativa, mas não deixam de ser menos punitivas, como as multas.

- Paradigma da eliminação seletiva: O sentido econômico da população com o advento do neoliberalismo retorna a enquadrar determinados segmentos da classe como supérfluo. Uma segregação historicamente econômica e étnica alinha-se a uma segregação territorial e a uma política de "guerra às drogas" que cria uma congruência para o retorno de uma abordagem estatal de seletiva eliminação populacional. "Desenvolvem-se esquemas de policiamento intensivo que primam por uma administração armada de uma população não encarcerada, a partir de uma abordagem territorial que delimita regiões urbanas especialmente policiáveis e policiadas com tal intensidade que o cotidiano pode ser descrito como a contínua aplicação de uma política penal" (OLIVEIRA, 2016, p. 259 - grifo original). 
Se por um lado, a política acionada é historicamente de administração da pobreza em seus segmentos mais pauperizados, por outro lado, ela contribui na reprodução das desigualdades sociais, como duas faces da mesma moeda. Para Baratta (2016, p. 166), a seletividade penal reproduz igualmente a verticalidade da sociedade, estigmatizando os estratos mais baixos da classe trabalhadora e praticamente impedindo a ascensão social desses. Portanto, ela é parte constitutiva, com papel ativo da execução penal, de produção e reprodução das relações de desigualdade da sociedade.

Todo esse processo funcional ao capital exige mediações ideológicas: operações espirituais que reproduzam no campo das ideias os interesses e as necessidades das classes dominantes, naturalizando as formas punitivas inerentes aos processos produtivos historicamente determinados.

Davis (2018, p. 17) expressa que as prisões ocultam os interesses e as convicções na defesa da sua própria perpetuação. Para Amaral (2016, p. 53), ela significa a legitimação ideológica do poder punitivo do Estado. Davis (2018, p. 17) acrescenta que ela representa a desresponsabilização da sociedade em lidar efetivamente com os efeitos do racismo e do capitalismo.

Na perspectiva de Ruiz (2016, p. 04), a prisão permite "associar as classes subalternas às classes perigosas, ao medo, à insegurança, à sensação de perigo". Cumpre papel elementar, nesse processo, a mídia que interessada no aumento de sua taxa de lucro preocupa-se mais em emocionar do que informar, sobretudo quando o assunto é crime (GOMES, 2015 Apud RUIZ, 2016, p. 05). Ela propicia uma relação adversarial (aliados $x$ inimigos) e, assim, uma visão maniqueísta da criminalidade, uma espécie de bem $x$ mal (ANDRADE, 2012, p. 284-287).

Araújo (2004) considera que a prisão distingue entre o bom e o mau cidadão. Ou nos termos de Souza (2015, p. 38), a prisão constitui os "exemplos de pessoas que não devem ser seguidas pelos demais cidadãos”.

Nos termos de Baratta (2016), embora a prisão seja a ponta do iceberg no processo de criminalização, ela opera ideológica e politicamente a construção do criminoso - ou seja, inversamente a proposta do discurso oficial de "ressocialização", ela fabrica o criminoso, assim como em oposição ao ideário de prevenção geral, ela não previne a criminalidade, mas consolida seletivamente a criminalização. 


\subsection{Humanização Penal.}

Em outra aproximação sucessiva das prisões, a partir dos estudos dos sistemas punitivos, percebe-se que a terminologia "humanização" é recorrida constantemente. Este termo não apenas carrega significados diversos como são historicamente determinados. Konder (2009) considera que os signos lexicais são permeados pelo movimento do real, refletindo em parte a própria dinâmica das lutas de classes em um período histórico determinado. Carregam em si um fundo político de disputa de ideias, que podem variar no tempo e no espaço. Por sua vez, Marx e Engels (2007) defendem que as disputas de ideias tendem a reproduzir os ideais da classe detentora do poder econômico. Isto demonstra que, em geral, as palavras tendem a reproduzir os significados implicados na defesa da sociabilidade e dos interesses dominantes.

Assim, há quem acredite que a lei do talião ${ }^{12}$ e o fim dos suplícios foram uma síntese histórica da humanização (LEMOS, 2010; FOUCALT, 2014); e outros que ainda acreditam que é possível humanizar as prisões a partir de reformas (AMARAL, 2016)

Para se refutar a tais perspectivas propõe-se um debate ontológico e histórico sobre humanização e prisões, respectivamente.

\subsubsection{Humanização: um debate ontológico.}

A humanidade se constitui como tal pela sua distinção elementar com os animais: o trabalho. Em outros termos, fundante da humanidade, enquanto ser social, o trabalho carrega em si os elementos distintivos entre ela e os animais (ainda que não deixe de pertencer à natureza).

Para Engels (2013, p. 13), “o trabalho é a condição básica e fundamental de toda a vida humana", em certo ponto, inclusive, criou o próprio ser humano. Por trabalho entende-se o processo relacional entre sujeito e natureza para produção e reprodução da própria espécie, extrair dali uma forma útil de

12 "Segundo Golin (2008), o talião consistiu em instrumento moderador da pena, de modo que a punição não poderia exceder a ofensa. Quanto à composição, o agressor podia deixar de receber a aflição imposta pelo ofendido, desde que ressarcisse o mal com bens" (LEMOS, 2010, p. 63). Trocando em miúdo: é a lei do olho por olho, dente por dente, isto é, a punição equivalente à infração. 
satisfação de necessidades sociais. A realização do trabalho, por outro lado, pressupõe a projeção prévia dos resultados (da forma útil, propriamente) - ou em outros termos, pressupõe atividade orientada a determinado fim (MARX, 1996a) -, o uso de intercessores instrumentais e/ou mediações de complexos de coisas, como propriedades mecânicas, físicas, químicas, etc. Decorre deste processo o surgimento de novas necessidades, impulsionando o desenvolvimento das capacidades humanas (MARX, 1996a).

Esta relação tem uma dupla dimensão: complementaridade e oposição. Ela se opõe na medida em que a cada passo dado na direção da produção de valores de uso distancia-se na mesma proporção da natureza, complexifica-se a relação do ser humano com ele próprio e suas formas de interação com a própria natureza e intensifica-se a variabilidade das necessidades sociais (MARX, 1996a); Ela se complementa na medida em que sem este metabolismo entre o ser social e a natureza inexiste a possibilidade de existência do próprio ser social, cuja base está assentada em compostos orgânicos e inorgânicos (LUKÁCS, 1997). Assim, o ser social "não deixa de ser animal, de pertencer à natureza; porém já não pertence inteiramente a ela" (KONDER, 2000, p.22).

Destarte, ontologicamente, o processo de humanização estaria relacionada com a capacidade do ser social de trabalhar em aproximação ao seu humanogenérico, propriamente o movimento da particularidade. A permanência da cisão, própria da cotidianidade nesta sociedade, entre o ser singular e o ser genérico implica na negligenciação da suspensão do cotidiano e da processualidade que dela se deriva: a humanização compulsória.

Esta humanização é a mediação entre o universal e o singular: a particularidade. É ela própria a constituição e o desenvolvimento das capacidades do ser social. Ao não realizar esta suspensão, prevalece-se a imediaticidade. Com isso, reforça-se a prática reiterativa (COELHO, 2012).

Em sociedades polarizadas em classes, como a capitalista, a constituição e o desenvolvimento das capacidades do ser social são substituídos pela desumanização, visto que o metabolismo entre o ser social e a natureza (o trabalho) é mediado pela exploração e alienação.

As características do trabalho na sociedade capitalista assumem formas peculiares. $\mathrm{Na}$ sociedade capitalista, o produto do trabalho passa por metamorfoses: (i) ele se contrapõe ao seu produtor direto (processo de alienação); 
(ii) ele assume a forma de relação entre coisas (processo de troca reificado); (iii) ele passa a exercer controle sobre seu produtor em relação ao tempo, ao espaço e a quantidade de trabalho (MARX, 1996a).

Este processo fetichista da mercadoria, porém, é a forma com que o capital mistifica sua real preocupação nos processos de trabalho: a exploração da força de trabalho para extrair o máximo de mais-valia. Esta exploração pode ser absoluta (extensão da jornada de trabalho) ou relativa (intensificação do trabalho), conforme Marx (1996a).

Essa redução do ser social à mera força de trabalho, alienado do produto de seu trabalho, inserido em relações coisificadas e controlado por interesses antagonicamente estranhos e hostis as suas necessidades constitui-se na desumanização do próprio ser social.

Portanto, uma acepção de humanização desvinculada da ontologia do ser social, ou seja, tomada como valor abstrato que desconhece a desumanização do ser social na sociedade capitalista, tende a defender a reiteração da ordem, isto é, há a defesa da realização de reformas prisionais - ainda que elas carreguem sentidos progressistas ou de atendimento a necessidades parciais da classe trabalhadora - em especial da superpopulação relativa, alvo privilegiado da política penal.

Essas tentativas de humanização penal ocorreram em diversos momentos da história. A realidade é que as condições degradantes, desumanas e cruéis permaneceram, e outros objetivos foram factualmente alcançados, conforme se pretende mostrar a seguir.

\subsubsection{Movimentos de reforma prisional.}

Davis (2018, p. 43) considera indissociáveis os termos reforma prisional. Um recurso historiográfico permite vislumbrar que o encarceramento fora considerado algo humano - em relação aos suplícios (punições corporais) e pena capital (DAVIS, 2018, p. 43), que ainda persistem em alguns países, como os Estados Unidos.

Pode-se dizer que a literatura clássica, como Beccaria (2004), defende uma humanização penal. Perseguiu, ainda no século XVIII, uma defesa de moderação das penas, caracterizando os suplícios e a pena de morte como inúteis. Pelo 
contrário, "a própria atrocidade da pena faz que [...] se cometam mais delitos para fugir a pena de um só” (BECCARIA, 2004, p. 72-73).

Troncos, pelourinhos, açoitamentos, marcação com ferro, amputações, ou seja, uma série de terríveis torturas marcavam as formas punitivas (DAVIS, 2018, p. 43-44). "Outros modos de punição que antecederam a ascensão da prisão incluem o banimento, o trabalho forçado em galés, o degredo e o confisco das propriedades do acusado" (DAVIS, 2018, p. 45).

Segundo Amaral (2016, p. 36), tratava-se da morte moral posteriormente a morte corporal, física, uma vez que os restos mortais eram expostos humilhantemente. Percebe-se que a prisão, como instituição, e a pena privativa de liberdade surgem em contraposição ao suplício que não mais se sustentava econômica e politicamente na sociedade moderna em consolidação, que passara a se basear em princípios opostos ao da sociedade feudal e constituía a forma tipicamente capitalista da propriedade privada.

Do período de acumulação primitiva do capital ao estágio superior do capitalismo - o imperialismo - em sua fase tardia, são indeléveis propostas reformistas ao sistema prisional, constantemente defendidas como propostas humanizadoras. Estas propostas nos permitem defender a constituição de minimamente cinco ondas reformistas ${ }^{13}$ :

- O primeiro movimento de reforma foca o próprio sujeito. É uma perspectiva de superação da mera retaliação, defendida por reformadores como John Howard e Benjamim Rush. (DAVIS, 2018, p. 44) John Howard "conceituava o aprisionamento como uma ocasião de autorreflexão religiosa e autorreforma" (DAVIS, 2018, p. 49), isto é, a perspectiva da reeducação moral.

- O segundo movimento de reforma defende transformações na estrutura física do espaço. Destaca-se Jeremy Bentham e seu modelo panóptico que consistia em um modelo arquitetônico de complexa projeção de vigilância e disciplina a ser internalizada pelo preso para aumento do trabalho produtivo.

- O terceiro movimento de reforma foca nos regimes penitenciários que pode ser subdivido em regimes não progressivos e regimes progressivos.

13 Não se pretende com esta afirmativa defender a hipótese de que os movimentos teriam ocorrido na ordem de tempo e no espaço em todos os países. Mas analisa-se o desenvolvimento clássico do modo de produção capitalista tendo por referência, nesse momento, a Europa e os Estados Unidos da América. Em países dependentes, como o Brasil, alguns desses movimentos ocorreram simultaneamente entre eles, além de concorrerem com a escravidão - o que forjou modos particulares de punição, em geral alinhado à vingança privada ou pública, definida pelos senhores brancos em conluio com o Estado. 
Nos regimes não-progressivos, destaca-se o regime pensilvânico com suas celas individuais, o silêncio, a solidão e a exclusividade da leitura bíblica (um isolamento completo) (DAVIS, 2018, p. 50-51). Não era permitido visitas nem direito a correspondências, e apenas era oferecido uma refeição diária (AMARAL, 2016, p. 43); outro regime foi o auburniano, igualmente, com celas individuais e o silêncio, porém com trabalho congregado (em grupo). Era vetado o entretenimento e o exercício físico. $\mathrm{O}$ produto do trabalho do preso era vendido abaixo do preço praticado no mercado (AMARAL, 2016, p. 43). "Por causa de suas práticas de trabalho mais eficientes, o modelo auburniano acabou se tornando dominante, tanto nos Estados Unidos quanto na Europa" (DAVIS, 2018, p. 51) por um longo período histórico. Os regimes progressivos são caracterizados por períodos de cumprimento de pena privativa de liberdade que progridem paulatinamente à liberdade e focados no mérito, no esforço individual e na boa conduta (AMARAL, 2016, p. 44-46). Atualmente, os regimes progressivos são considerados etapas obrigatórias no cumprimento da pena, calculado a partir de frações do tempo total da condenação. Entretanto, ainda podem ser postergados ou retroagidos por comportamento não cordato do preso.

- O quarto movimento de reforma é caracterizado pela construção de presídios (e regime) de segurança supermáxima. Desaparece a ideia de reabilitação individual e retorna o confinamento solitário e a proibição de atividades conjuntas e comunicação entre presos (privação sensorial). Usase de tecnologia moderna e sofisticada para monitorar e controlar os movimentos e comportamentos dos presos (DAVIS, 2018, p. 53-54). "O que já foi considerado progressista e até mesmo revolucionário representa hoje a união da superioridade tecnológica com o atraso político" (DAVIS, 2018, p. 54) ${ }^{14}$.

- O quinto movimento de reforma é, na concretude, uma contrarreforma. Enfraquece-se os ideais "re" (ressocialização, reinserção, reeducação, readaptação do condenado, etc.); retoma-se os ideais retributivos (AMARAL, 2016, p. 41) e autoritários em defesa abstrata da segurança pública e dos "humanos direitos". Davis (2018, p. 61-63) expõe a revogação do financiamento universitário para presos, a extinção da escrita e de outros programas educacionais como indicadores consoantes com a nova fase prisional, nos Estados Unidos, de expansão da prisão e da repressão em seu interior. Amaral (2016, p. 41) credita à crise do Estado de bem-estar social a uma espécie de minamento das políticas sociais e das perspectivas a ele alinhado, como o modelo ressocializador, e acrescentase a retração do investimento público nas prisões.

Percebe-se que o foco dos reformadores dos séculos XVIII e XIX era criar condições de punição baseadas no confinamento solitário (DAVIS, 2018, p. 51).

14 "A justificativa predominante para a prisão de segurança supermáxima é que os horrores que ela cria são o complemento perfeito para as personalidades monstruosas consideradas o que há de pior pelo sistema prisional. Em outras palavras, não há a falsa aparência de que direitos são respeitados, não há preocupação com o indivíduo, não há a noção de que os homens e mulheres encarcerados em prisões de segurança supermáxima merecem qualquer coisa que se aproxime de respeito e conforto" (DAVIS, 2018, p. 54) 
Uma crítica pioneira foi a de Charles Dickens que observou um potencial efeito de insanidade na população carcerária, defendendo que aqueles submetidos retornarão ao convívio social insalubre e doente (DAVIS, 2018, p. 51-52). Amaral (2016, p. 43) considerou os regimes penitenciários ${ }^{15}$ contraproducente em relação as suas (falaciosas) finalidades, além de embrutecer e enlouquecer os presos.

O ponto comum são as estratégias para transformar hábitos e moral (DAVIS, 2018, p. 55) e a constituição de exército de indivíduos autodisciplinados para o nascente trabalho industrial (DAVIS, 2018, p. 50). O ponto divergente é o olhar sob o qual a transformação em si ocorrerá. Por outro lado, as propostas reformistas contemporâneas operam o desmonte das limitadas reformas precedentes.

"Os reformadores do século XVIII criticavam as antigas prisões por seu caos, sua falta de organização e classificação, pela livre circulação de álcool, pela prostituição e pela incidência de enfermidades e doenças contagiosas" (DAVIS, 2018, p. 56) e prosperava o suborno de guardas (DAVIS, 2018, p. 56). Estas palavras atualíssimas sobre o sistema penitenciário conotam que a emergência da prisão como punição por excelência da sociedade moderna surge em absoluta contraposição aos próprios valores burgueses e a sua ideia de humanização ${ }^{16}$. Expressa, por um lado, uma condição constitutiva. Por outro lado, a prisão nasce aparentemente obsoleta. Entretanto, uma análise a partir da totalidade concreta apreende, por sua vez, um conjunto de funções e utilidades opostas ao que se pronuncia historicamente papel da prisão.

15 Amaral (2016) denomina, na verdade, de sistema penitenciário. Diverge-se da nomenclatura adotada por se compreender que sistema penitenciário engloba um conjunto de questões que incluem os regimes adotados no interior das prisões, mas que não se limitam a eles.

16 Baseia-se no ideário revolucionário para seu tempo, positivado na Declaração dos Direitos do Homem e do Cidadão: liberdade, igualdade e fraternidade. Para uma crítica à declaração, conferir Marx, 2009. 


\title{
2. SERVIÇO SOCIAL E PRISÕES.
}

\begin{abstract}
A história da política pública para mendigos e pobres somente pode ser compreendida se relacionamos a caridade com o direito penal.

(RUSCHE e KIRCHHEIMER, 2004, p. $58)$.
\end{abstract}

As estratégias do capital de manutenção da ordem social, no estágio dos monopólios, incluíram a profissionalização de práticas que desbordassem a repressão e a caridade frente à agudização das contradições do próprio capital (FORTI, 2008, p. 176), soma-se a isso o projeto de recuperação de hegemonia pela Igreja Católica, sobretudo na sua proposta reformista de conciliação de classes presentes na Encíclica Papal Rerum Novarum (FORTI, 2008, p. 175). Esses elementos constituem a base material e a direção ideológica que fundam o Serviço Social, no Brasil, em meados da década de 1930.

Assim, no âmbito do Serviço Social, a defesa de reformas tem lastro histórico fincado na sua emergência confessional: o projeto reformistaconservador sob a ótica cristã que recorre a uma determinada perspectiva de humanização: igualdade perante Deus e contenção das lutas de classes - a partir do controle aos excessos dos capitalistas e da educação moral aos trabalhadores (ORTIZ, 2007, p. 135).

Historicamente, a própria motivação da procura ao Serviço Social pelo alunado tende a estar relacionada à imagem social da profissão (ORTIZ, 2007): à profissão da ajuda guiada por valores altruístas e não utilitários, embora o mercado esteja associado direta ou indiretamente (ORTIZ, 2007). Ou nos termos de Iamamoto (Apud ORTIZ, 2007), “busca-se também uma profissão que veicule vantagens simbólicas, no campo da 'solidariedade humana', da 'realização pessoal', da oportunidade de realizar uma 'vocação', inspirada em motivações religiosas ou claramente políticas”.

Essas questões revelam, ao menos, duas características da institucionalização do Serviço Social no Brasil: (i) a marcante presença da Igreja Católica na direção, organização e norte ideológico (NETTO, 2007a) - inclusive com as encíclicas papais subsidiando a doutrinação das famílias trabalhadoras (IAMAMOTO, 2004, p. 19; OLIVEIRA e CHAVES, 2016); e (ii) o caráter 
militante/messiânico do corpo docente e discente de Serviço Social ${ }^{17}$ (IAMAMAMOTO, 2004, p. 20).

Ao realizar-se, assim, combinando profissionalização e militância católica, a institucionalização do Serviço Social desenvolveu um lastro histórico e percepções da realidade distorcidas, induzindo ao pensamento que a profissão derivaria de um processo evolutivo da ajuda (NETTO, 2007a, p. 73), uma espécie de continuum da filantropia, enquanto chamado ${ }^{18}$ do humanismo cristão.

Entretanto, quando o Serviço Social tradicional ${ }^{19}$ entra em crise e segmentos da categoria se aproximam da tradição marxista, nos processos denominados de Movimento de Reconceituação e de Renovação do Serviço Social $^{20}$, a institucionalização é plenamente revelada: o Serviço Social constitui-se como profissão quando rompe com suas protoformas (ainda que conserve suportes institucionais e organizativos) e torna-se fruto da necessidade histórica do capitalismo, em seu estágio superior, de enfrentamento à chamada "questão social" ${ }^{21}$ (NETTO, 2007a, p. 79).

\footnotetext{
${ }^{17}$ A profissão se apresentava no início de sua emergência como uma alternativa profissionalizante às militantes católicas e seu apostolado social, que baseado nas encíclicas papais deveria recristiniazar as famílias trabalhadoras, em um processo de luta contra o socialismo e o liberalismo (IAMAMOTO, 2004). Quando a profissão se consolida e ocorrem transformações sociais na década entre 1960 e 1980 que serão absorvidas pela categoria e que incidirão na renovação profissional, esse caráter militante é ressignificado ideologicamente: agora em perspectiva laica, a militância influenciará na direção social e política da profissão, reconhecendo a classe trabalhadora como sujeito histórico e revolucionário.

18Inclusive, este processo se agrava quando situado no bojo da conformação do exército assistencial de reserva, pois potencializa o recurso ao voluntariado e ao "chamamento à solidariedade", exponenciado por múltiplas determinações, em especial o aligeiramento da formação profissional - sobretudo (mas não exclusivamente) o ensino a distância -, da criminalização e moralização da "questão social" e da assistencialização das políticas públicas (IAMAMOTO, 2009)

${ }^{19}$ "Creio que é necessário distinguir claramente Serviço Social 'clássico' de Serviço Social 'tradicional'. Serviço Social 'clássico' denota o exercício profissional tal como foi postulado pelos agentes profissionais que se dedicaram a um mínimo de sistematização, constituindo de fato as fontes do Serviço Social (Mary Richmond é o exemplo mais típico). Por Serviço Social 'tradicional' deve entender-se a prática empirista, reiterativa, paliativa e burocratizada que os agentes realizam efetivamente na América Latina. Evidentemente, há um nexo essencial entre ambos: parametra-os uma ética liberal-burguesa e sua teleologia consiste na correção - numa ótica claramente funcionalista - de resultantes psicossociais considerados negativos ou indesejáveis, sobre o substrato de uma concepção (aberta ou velada) idealista e/ou mecanicista da dinâmica social, sempre pressuposta a ordenação capitalista da vida como um dado factual ineliminável" (NETTO, 1981, p. 59-60).

${ }^{20}$ Cf. infra, nota 09 .

${ }^{21}$ Segundo Netto (2007, p. 154-157), a expressão "questão social" surge para situar o pauperismo enquanto fenômeno novo e seus desdobramentos sociopolíticos. Anteriormente utilizada por distintos espectros políticos, seu uso desliza para o vocabulário conservador e torna-se objeto de ação moralizadora. Seu resgate pela teoria social crítica desvela sua anatomia: a lei geral de acumulação capitalista e a rebeldia das classes exploradas.
} 
Por sua vez, ainda que tenham ocorrido às mudanças substantivas na autoimagem profissional, derivada da interlocução com o marxismo e com a conformação do projeto ético-político ${ }^{22}$, não se eliminam as contradições intrínsecas à própria estrutura do Serviço Social: (i) reprodução pela mesma atividade dos interesses antagônicos das classes sociais fundamentais (IAMAMOTO e CARVALHO, 2012, p. 81 - grifo original); (ii) tendências a ser cooptado pelas ideias dominantes (IAMAMOTO e CARVALHO, 2012, p. 81); (iii) processualidade profissional consoante aos estágios de acumulação e valorização do capital (NETTO, 2007a, p. 79); (iv) inespecificidade operatória (NETTO, 2007a, p. 104); e (v) saberes ecléticos (NETTO, 2007a).

Por outro lado, a condição para optar entre uma classe ou outra emerge exatamente da análise concreta da realidade. Ou seja, apenas depois de tomada conhecimento das contradições inerentes à profissão a categoria pôde assumir conscientemente uma direção social e política ${ }^{23}$ sem distorções da realidade.

Com este olhar crítico sobre a realidade e a profissão, o assistente social, enquanto técnico especializado no trabalho coletivo, cujo objeto de intervenção são os efeitos deletérios da "questão social", pode ter a humanização abstrata como discurso de trabalho nas prisões minimamente por uma dupla dinâmica: (i) pelo processo de institucionalização do Serviço Social e o histórico traço humanista de sua imagem social; e (ii) pelas requisições na divisão social e técnica do trabalho - doravante denominada de requisições institucionais por se referir precisamente às exigências institucionais do sistema prisional ao Serviço Social, isto é, a ordem que emana do poder instituído, que nessa sociedade reflete necessariamente as contradições entre as classes sociais fundamentais.

Segundo Foucault (2014, p.16), o exército de técnicos que há séculos substituíram o carrasco no processo de execução penal tem o papel de tentar

\footnotetext{
${ }^{22}$ Em estudos anteriores, indica-se a seguinte síntese sobre o projeto ético-político do Serviço Social: "a construção do projeto profissional do Serviço Social brasileiro foi/é coletiva, historicamente datada e organicamente vinculada a um projeto societário: é fruto e expressão de um amplo movimento de lutas pela democratização da sociedade e do Estado no país que questionavam a autocracia burguesa e seus influxos na profissão, bem como a funcionalidade do exercício profissional na reprodução da ordem societária vigente, refletindo, assim, o acúmulo de discussões, polêmicas e proposições, das últimas décadas, no âmbito do conjunto profissional" (CONCEIÇÃO, 2016, p. 36)

${ }^{23}$ Em síntese, esta direção social e política se expressa, segundo Iamamoto (2011b, p. 224-225), nos seus instrumentos legais; nas expressões e manifestações coletivas da categoria; nas articulações com outras entidades de Serviço Social e com outras categorias profissionais e movimentos sociais organizados; no trabalho profissional desenvolvido nos diferentes espaços ocupacionais; e no ensino universitário.
} 
garantir que o corpo e a dor não sejam objetos últimos de sua ação punitiva. Há, no Serviço Social, quem defenda essa perspectiva como possível: “o Serviço Social coloca-se a atender as necessidades do preso, dos apenados e do egresso a participar do retorno ao meio social e vir a garantir um tratamento mais humano e digno" (QUEIROZ, BORBA, PICHELLI e OLIVEIRA, 2009, p. 123).

As violências e violações de direitos persistem nas prisões em âmbito internacional. Essa condição - que a partir da análise dos movimentos de reformas prisionais - nos parece ser histórica e indissociável permitiu debates no âmbito das organizações internacional, em especial da Organização das Nações Unidas (ONU), que se desdobraram em preceituações internacionais:

\footnotetext{
"No século XX, reconhecendo a propensão de pessoas presas a sofrerem violações de direitos humanos, a Organização das Nações Unidas - ONU estabeleceu as Regras Mínimas para o Tratamento dos Presos em 1955, os Princípios para Proteção para todas as Pessoas Sujeitas a Qualquer Forma de Detenção ou Prisão em 1988, tais regras atribuíam caráter humanitário à prisão que, estabelecendo princípios que não ferissem a dignidade humana, sem distinção" (FERREIRA e OLIVEIRA, 2016, P. 5).
}

Em relação à humanização, Ferreira (2014, p. 18) a percebe como parte da atuação profissional, mas sob o dilema da correlação de força instituída que a tornaria desacreditada. Queiroz, Borba, Pichelli e Oliveira (2009, p. 124), na mesma direção, defendem uma ação socioeducativa do assistente social direcionada à liberdade do preso com objetivo humanizador.

Assim, tomada como valor abstrato, a humanização, embora possa representar uma luta progressista, ela reforça a naturalização das prisões e rejeita a indissociabilidade dos termos reforma prisional, e na particularidade da institucionalização do Serviço Social no Brasil carrega consigo o reajustamento do preso, a importância da família como principal estrutura de redenção e a individualização e moralização da "questão social”.

\subsection{As requisições institucionais das prisões ao Serviço Social brasileiro.}

As requisições institucionais ao Serviço Social no sistema prisional reforçam essa perspectiva de humanização como valor abstrato. De acordo com a Lei de Execução Penal (LEP) no 7.210 de 11 de julho de 1984 (BRASIL, 1984), in verbis do caput do artigo $3^{\circ}$ : "ao condenado e ao internado serão assegurados 
todos os direitos não atingidos pela sentença ou lei”. A afirmação do direito pela sua negação é por si só uma síntese da complexa realidade prisional e das possibilidades profissionais no interior do referido espaço ocupacional.

Em relação à LEP, há no Serviço Social quem credite a ela uma dimensão de "criação de instrumentos humanos que promovam a ressocialização da pessoa privada de liberdade proporcionando a sua inserção ao convívio social" (GONÇALVES, 2017, p. 252), ou seja, além de recair no canto da sereia do discurso oficial da prevenção especial positiva da teoria das penas, há a crença de que uma lei a qual houve escassa discussão e participação popular na sua formulação, e que persiste por anos assim, carregue a possibilidade de ser um instrumento de humanização. Foucault (2014) ao expressar ser uma ingenuidade acreditar que a privação de direitos (e de liberdade) por si só são menos violento que o suplício contrapõe a essa ideia de possibilidade humanização nas prisões - e ele sequer parte da concepção de ser social aqui defendida.

Nos termos da LEP, entendem-se como requisição ao Serviço Social dois motes de intervenção: (i) a assistência social ao preso, ao internado, ao egresso e à vítima; e (ii) a classificação, a individualização e a fiscalização da pena e da pessoa privada de liberdade.

Observa-se que tais motes não lhe são exclusivos, uma das requisições que lhe é privativa, na concepção de profissão expressa na LEP, verificável nas exigências institucionais e, conforme Valerai (2012), pelo Departamento Penitenciário Nacional (DEPEN), é a assistência social.

De acordo com Valerai (2012), na época de promulgação da LEP, eram sinônimos os termos "Serviço Social" e "assistência social". No Rio de Janeiro, Pereira (1984) reconhece como desafio à época (entre os anos de 1975 e 1984) lutar pela dissociação entre "assistência social" e "Serviço Social" como sinônimo. Apenas em 1986 que, no Rio de Janeiro, o Regulamento do Sistema Penal do Estado do Rio de Janeiro (RPERJ) reconhece essa distinção. Mas na LEP segue ainda como assistência social parte das requisições institucionais ao Serviço Social.

A LEP (BRASIL, 1984) descreve as competências da assistência social in verbis: 
Art. 23. Incumbe ao serviço de assistência social:

I - conhecer os resultados dos diagnósticos ou exames;

II - relatar, por escrito, ao Diretor do estabelecimento, os problemas e as dificuldades enfrentadas pelo assistido;

III - acompanhar o resultado das permissões de saídas e das saídas temporárias;

IV - promover, no estabelecimento, pelos meios disponíveis, a recreação;

$\mathrm{V}$ - promover a orientação do assistido, na fase final do cumprimento da pena, e do liberando, de modo a facilitar o seu retorno à liberdade;

VI - providenciar a obtenção de documentos, dos benefícios da Previdência Social e do seguro por acidente no trabalho;

VII - orientar e amparar, quando necessário, a família do preso, do internado e da vítima.

$[\ldots]$

Nota-se que a profissão requisitada é uma que meramente executa terminalmente as políticas sociais (NETTO, 2007). Prevalece-se requisições de ações de cunho burocratizadas e imediatistas e, quando muito, as de articulações de rede socioassistencial. Perde-se (exclui-se, na verdade) as ações socioeducativas - ou pedagógicas ${ }^{24}$, nos termos de Abreu (2011) - e as dimensões de (a) mobilização, participação e controle social; (b) investigação, planejamento e gestão; e (c) assessoria, qualificação e formação profissional. Portanto, a LEP expressa a exigência de uma profissão que reforce a conexão imediata entre pensamento e ação. Uma mera manipulação de variáveis empíricas.

Causa-nos inquietude as propostas de promover recreação e a pontualidade da orientação ao preso na fase final da reclusão. A permanência das referidas preceituações, após três décadas da promulgação da lei, representam um passado profissional que, desde o final da década de $1970^{25}$, se pretende superar: o primeiro não condiz com as atuais atribuições privativas do Serviço Social, sua proposição seria admissível - não isenta de polêmicas - em uma perspectiva interdisciplinar, como competência multiprofissional, não como atribuição privativa (LEMOS, 2010); o segundo representa o tecnicismo. Segundo Lemos (2010), cabe ao assistente social realizar um trabalho contínuo, conjunto,

24 Salta, aqui, uma preocupação histórica. As prisões, historicamente, têm buscado imprimir uma prática "reeducadora", ora pelo trabalho forçado e penoso, ora pela imposição moral e religiosa, bem como a conjugação de ambas. A prática pedagógica, no sentido de Abreu pode ser divididas em três: na função pedagógica da ajuda, da participação e da emancipação. Entende-se que as duas iniciais reforçariam o papel anteriormente citado e a terceira questionaria.

${ }^{25}$ Em setembro de 1979, ocorreu o III Congresso Brasileiro de Assistentes Social. Para Netto (2009, p. 31) "o III Congresso quebrou o monopólio conservador nas instâncias e fóruns da categoria profissional". Desde, então, tem se convencionado chama-lo de "Congresso da Virada". 
respeitoso e interativo. Empreendendo esforços, individuais e coletivos, o trabalho do assistente social nas prisões deve desbordar a imediaticidade.

Segundo a LEP (BRASIL, 1984), outras atribuições privativas são previstas nos artigos 25, da assistência ao egresso, e 80, do Conselho da Comunidade, in verbis:

Art.25. A assistência ao egresso consiste:

I - na orientação e apoio para reintegrá-lo à vida em liberdade;

II - na concessão, se necessário, de alojamento e alimentação, em estabelecimento adequado, pelo prazo de 2 (dois) meses.

Parágrafo Único. O prazo estabelecido no inciso II poderá ser prorrogado uma única vez, comprovado, por declaração de assistente social, o empenho na obtenção de emprego.

[...]

Art. 80. Haverá, em cada comarca, um Conselho da Comunidade, composto, no mínimo, por 1 (um) representante de associação comercial ou industrial, 1 (um) advogado indicado pela Seção da Ordem dos Advogados do Brasil, 1 (um) Defensor Público indicado pelo Defensor Público Geral e 1 (um) assistente social escolhido pela Delegacia Seccional do Conselho Nacional de Assistentes Sociais.

Art. 81. Incumbe ao Conselho da Comunidade:

I - visitar, pelo menos mensalmente, os estabelecimentos penais existentes na comarca;

II - entrevistar presos;

III - apresentar relatórios mensais ao Juiz da execução e ao Conselho Penitenciário;

IV - diligenciar a obtenção de recursos materiais e humanos para melhor assistência ao preso ou internado, em harmonia com a direção do estabelecimento.

De acordo com Araújo (2017), raros são os programas direcionados ao egresso que são efetivados pelo Estado nas unidades de regime semiaberto e aberto, como o Patronato ${ }^{26}$.

Embora haja a requisição ao Serviço Social de colaborar na obtenção de trabalho e na orientação e apoio à liberdade, estas dificilmente têm sido realizadas pelo Patronato, quiçá nas unidades de regime semiaberto. E tem-se como hipótese que, a partir do debate das funções econômicas das prisões, o Serviço Social é uma das profissões que reproduzem a busca de emprego nos nichos mais precários do mercado de trabalho.

\footnotetext{
${ }^{26}$ De acordo com o artigo 78 da LEP, "o Patronato público ou particular destina-se a prestar assistência aos albergados e aos egressos". Compete também ao Patronato a orientação aos condenados à pena restritiva de direitos; a fiscalização do cumprimento das penas de prestação de serviço à comunidade e de limitação de fim de semana; e a colaboração na fiscalização do cumprimento das condições da suspensão e do livramento condicional (BRASIL, 1984). Ou seja, trata-se de uma instituição penal, pública ou privada, que deveria garantir desde à assistência ao preso à fiscalização da execução penal.
} 
Causa-nos inquietação, igualmente, o papel policialesco atribuído ao Serviço Social de apreender o empenho do egresso em obter emprego. Ultrapassase, em demasia, das atribuições e competências profissionais esta requisição fiscalizatória, que remonta aos primórdios da profissão, que desvincula as funções ideológicas das prisões (como o estigma) sobre as vidas dessa fração da classe trabalhadora e também não compreende a necessidade de existência da superpopulação relativa ao processo de acumulação e valorização do capital. Portanto, declarar positiva ou negativamente o empenho em obter emprego corresponde à moralização das expressões da "questão social", no caso o desemprego.

Esta preocupação se intensifica na medida em que quem cumpre a assistência ao egresso, em geral, são as Organizações Não Governamentais (ONG) e as instituições religiosas, dando a direção social que lhes convir. Araújo (2017) registra uma experiência particular no Banco da Providência ${ }^{27}$, no Rio de Janeiro. Em seu ensaio, ela apresenta o Curso de Preparação para o Mundo do Trabalho, organizado pelo Serviço Social da referida instituição, para atender aos egressos do sistema prisional. Ela apreende a existência paradoxal entre práticas que revelam traços conservadores, a retórica da garantia de direitos e o impacto, ainda que mínimo, do curso na vida dos egressos.

Por sua vez, o Conselho da Comunidade pode, em um olhar superficial, iludir a compreensão factual do espaço, pois ele aparenta ser um ambiente de voz dos presos (inciso II do artigo 81) e de estar preocupado com o envolvimento da sociedade nos rumos intramuros (devido a sua composição por agentes externos ao quadro de funcionários das prisões: representantes de associações comerciais, dos advogados, da defensoria pública e dos assistentes sociais).

Entretanto, de acordo com o Parecer Jurídico 08/00 do Conselho Federal do Serviço Social (CFESS), o caráter político-participativo do conselho é ausente, e muito diferente da proposta dos conselhos de direitos e de políticas ${ }^{28}$. Em

\footnotetext{
${ }^{27}$ Fundado por Dom Helder Câmara, o "Banco da Providência é uma organização social sem fins lucrativos que há 59 anos trabalha para contribuir na redução da desigualdade social e colaborar para a defesa dos direitos de jovens, adultos e famílias que vivem em situação de pobreza extrema na cidade do Rio de Janeiro, através dos projetos de capacitação profissional e geração de renda. A ação estratégica está concentrada em 5 bairros que abrangem 60 comunidades com os mais baixos índices de desenvolvimento humano (IDH)".

${ }^{28}$ Os conselhos e as conferências são, segundo Bravo e Correia (2012), arenas de disputa de interesses - ainda que a luta de classes não se esgote neles. São sínteses históricas da luta pela
} 
relação ao Serviço Social, há ali uma atuação profissional, a partir de um saber técnico, responsável ética e politicamente por suas ações e a prestação gratuita de um serviço técnico, assim como o requerimento das ações profissionais são de caráter assistencialista e inexistem recursos ou fundos específicos para o setor cabendo, inclusive, aos profissionais captarem os recursos. O trabalho do assistente social do Conselho da Comunidade não é integrado ao do Serviço Social nas unidades prisionais, sendo ações sem alinhamento coletivo.

Em relação à requisição de classificação, individualização e fiscalização da pena e da pessoa privada de liberdade, o Serviço Social, ainda que não exclusivamente, tem sido exaustivamente requisitado na elaboração de laudos e pareceres sociais - e perceba que não há "confusão" entre Serviço Social e assistência social, e sim a designação explícita da profissão.

A LEP expõe in verbis:

Art. $7^{\circ}$ A Comissão Técnica de Classificação, existente em cada estabelecimento, será presidida pelo diretor e composta, no mínimo, por 2 (dois) chefes de serviço, 1 (um) psiquiatra, 1 (um) psicólogo e 1 (um) assistente social, quando se tratar de condenado à pena privativa de liberdade.

Parágrafo Único. Nos demais casos a Comissão atuará junto ao Juízo da Execução e será integrada por fiscais do Serviço Social.

[...]

Art. 139. A observação cautelar e a proteção realizadas por Serviço Social penitenciário, Patronato ou Conselho da Comunidade terão a finalidade de:

I - Fazer observar o cumprimento das condições especificadas na sentença concessiva do benefício;

II - Proteger o beneficiário, orientando-o na execução de suas obrigações e auxiliando-o na obtenção de atividade laborativa.

[...]

$\S 3^{\circ}$ do art. 158. A fiscalização do cumprimento das condições reguladas nos Estados, Territórios e Distrito Federal por normas supletivas, será atribuída a Serviço Social penitenciário, Patronato, Conselho de Comunidade ou Instituição beneficiada com a prestação de serviços, inspecionados pelo Conselho Penitenciário, pelo Ministério Público, ou ambos, devendo o Juiz da execução suprir, por ato, a falta das normas supletivas.

Estas requisições institucionais de individualização e classificação denotam o caráter punitivo do trabalho profissional nas prisões. São ações, em geral, de fiscalização e monitoramento, isto é, ações policialescas à pessoa privada de liberdade com o intuito de garantir a ordem intramuros (a disciplina, como função política das prisões).

redemocratização do país e aprofundamento da participação da sociedade nos rumos do Estado invertendo a lógica de controle social, que antes era realizada pelo Estado em relação à sociedade. 
A individualização e a classificação ${ }^{29}$ têm sido recorridas para intensificar a punição intramuros. Em estudos anteriores, constatou-se que:

O relatório do Departamento Penitenciário Nacional (DEPEN) acerca da situação da [Comissão Técnica de Classificação] (CTC) no país expressa a situação caótica do sistema prisional: 15 unidades federativas (UF) não possuem a CTC conforme a LEP determina e outras $3 \mathrm{UF}$ até tem CTC, mas com algumas observações (em geral, em algumas unidades prisionais e não em sua totalidade). O Rio de Janeiro, segundo o mesmo relatório, é uma UF que tem CTC em todas as unidades. Mas esse relatório omite um dado muito importante da realidade: ao menos nas unidades prisionais que as partícipes do [Grupo de Integração e Discussão de Estagiárias do Serviço Social na Secretaria de Administração Penitenciária do Rio de Janeiro] (GIDESS) estavam lotadas, as CTCs não eram realizadas conforme a LEP no que diz respeito à composição. Elas eram orquestradas errônea e criminalmente sem a participação da equipe técnica, que meramente assinava a documentação de uma suposta CTC e muitas das vezes sem lê-las, assumindo responsabilidade por um conteúdo desconhecido e que pode estar reforçando toda a lógica prisional. (CONCEIÇÃO, 2016, p. 71),

Para Marques (2009), as condições de escassez de assistentes sociais e de imensas demandas foram responsáveis por reduzir o trabalho profissional à elaboração de laudos e pareceres. No entanto, conforme constatado em estudos anteriores (CONCEIÇÃO, 2016), a situação complexa das prisões em relação à inexistência e forjamento da existência das CTCs em mais da metade do país, assim como aos demais elementos supracitados, reforça a perspectiva da existência de funções nas prisões para além do discurso oficial.

Acrescenta-se a existência de conflitos éticos do profissional ao reforçar esta farsa das CTCs quando eles meramente assinam a documentação de uma suposta comissão (CONCEIÇÃO, 2016, p. 71-72) - ainda que as condições de trabalho sejam precárias, a correlação de forças desfavorável e impere o arbítrio nas prisões, assinar documento aleatoriamente assumindo responsabilidade por conteúdo desconhecido é injustificável eticamente.

Para legitimar este processo, o Serviço Social (ao lado de outras profissões, como a Psicologia e a Medicina - em específico a especializada em Psiquiatria) é requisitado pelo Poder Judiciário, apesar do entendimento

\footnotetext{
29 "A ideia de individualização é corroborar com que cada indivíduo possa ser descrito, analisado e 'classificado', passível então de uma 'mudança' moral e social a partir de uma avaliação submetida ao Sistema Penal. Na prática o que observamos é que o conceito de individualização consiste no isolamento do preso por alguns dias para se investigar se o mesmo possui inimigos no interior do presídio" (NASCIMENTO, 2013).
} 
controverso do Supremo Tribunal Federal (STF), para elaborar o exame criminológico, sobretudo no Rio de Janeiro ${ }^{30}$.

Segundo Valerai (2012, p. 09-10),

A lei $\mathrm{n}^{\circ} 10.792 / 2003$ alterou a redação dos artigos $6^{\circ}$ e 112 da LEP, excluindo a necessidade do exame criminológico. A nova redação determina que o preso tem direito à progressão de regime depois de cumprir ao menos um sexto da pena e apresentar bom comportamento carcerário.[...] Como o novo texto não faz qualquer referência ao exame criminológico, o Supremo Tribunal Federal, decidiu que, apesar da lei ter excluído o exame criminológico, nada impede que os magistrados determinem sua realização, sempre que julgarem necessário para embasar a sua decisão, considerando as peculiaridades do caso.

De acordo com o parágrafo único do artigo 83 do Código Penal Brasileiro (CPB), positivado na lei de número 2.848 de 07 de dezembro de 1940, "a concessão do livramento ficará também subordinada à constatação de condições pessoais que façam presumir que o liberado não voltará a delinquir" (grifos não originais). Esse instrumental resultado de estudo hipotético e acrítico e longe de qualquer dimensão teórico-metodológica da profissão (CFESS, 2014), recebeu a nominação de exame criminológico e o atribuiu como competência das profissões de Psicologia, Psiquiatria e Serviço Social.

Tal instrumento extensivo do poder de julgar do juiz à esfera do executivo, o exame criminológico recebe críticas, em especial - ainda que não exclusivamente-, da Psicologia e do Serviço Social. Para Freitas (2013), sua realização causa incomodo e desrespeito às questões éticas. Para o CFESS (2014, p. 69),

O exame criminológico parte de uma concepção positivista de intervenção profissional, que afirme uma verdade a-histórica sobre o comportamento moral de um indivíduo. Tem como objetivo presumir uma possível reincidência do/a preso/a. Nosso questionamento é: em que medida é possível construir parâmetros de avaliação que prevejam uma possível reincidência criminosa no futuro, sem que o ato criminoso seja considerado de total responsabilidade do indivíduo? A ciência é capaz de prever comportamentos futuros a partir de avaliação de personalidade? E mais grave: a avaliação de possíveis

30 De acordo com Nascimento (2013), o Rio de Janeiro ainda adota o exame criminológico para a concessão de "benefícios" (não seriam direitos?). Os juízes da Vara de Execução Penal insistem no pedido generalizado do exame. 
reincidências é feita a partir de avaliações comportamentais e disciplinares do indivíduo durante o período em que esteve cumprindo a pena, em condições absolutamente adversas, em que muitos (senão todos) dos seus direitos foram violados.

Para Marques (2009), além de ser peça do processo penal, o exame criminológico cumpre a função social simbólica - ideológica - de justificar o desacreditável (tratamento penal) e o desacreditado (preso). Ela alega que os assistentes sociais revelam "em seus pareceres, muitas vezes, conteúdos moralistas e segregadores, carregados daquele olhar lombrosiano e darwinista social erguido no século XIX e tão presente até os dias de hoje” (idem, p. 10). No termos de Nascimento (2013), os laudos mesclam perspectivas morais e sociais que combinam positivismo, violência e injustiça. E tem como função fornecer informações de tempo, espaço e hábitos da pessoa privada de liberdade.

Portanto, o exame criminológico está em conflito com o projeto éticopolítico, uma vez que sua premissa é aferir a personalidade do preso, medição de periculosidade e determinação de reincidência ou não. Frente a este quadro, desde 2014, o conjunto CFESS-CRESS tem como resolução o posicionamento contrário à existência do exame criminológico (CFESS, 2014).

Há, portanto, incongruência e/ou tensões entre as requisições institucionais e o projeto ético-político, ainda que ambos datem de períodos históricos distintos.

\subsection{A institucionalização do Serviço Social nas prisões fluminense.}

Em 68 anos de atividades do Serviço Social nas prisões fluminenses (1951-2019), a profissão vivenciou mudanças na sua autoimagem profissional e relativamente uma manutenção de requisições institucionais - ainda que no âmbito de sua organização, reconhecimento profissional e autonomia técnica houvesse alterações determinadas contraditoriamente ora pela racionalização do Estado, ora pela consciência de seus próprios profissionais.

Entre a fundação da primeira Escola de Serviço Social no Rio de Janeiro e o início das atividades de Serviço Social nas prisões fluminense transcorreram apenas 14 anos: data de 1951 o começo da trajetória do Serviço Social nas prisões do Rio de Janeiro em caráter não oficial (VASCONCELOS, et al, 2004) e voluntário (SANTOS, 1987; FORTI, 2008). 
Institucionalmente, em 1954, foi reconhecido no artigo $3^{\circ}$ e regulamentado pelo artigo 16 do Decreto Federal $\mathrm{n}^{\circ} 35.076$ daquele ano (BRASIL, 1954; VASCONCELOS et al, 2004; FORTI, 2008). O Decreto assim definia as requisições ao Serviço Social:

Art. 16. Ao C.S.S [Centro de Serviço Social]. compete:

I - estudar e diagnosticar os casos sociais relativos às famílias dos sentenciados e presos, realizando, para êsse fim, quando houver autorização do interessado, as visitas domiciliares necessárias;

II - promover o tratamento dos casos sociais, por intermédio das associações a que se refere o item VII;

III - manter um fichário dos casos sociais;

IV - informar a S.C.R [Seção de Registro e Controle]., sôbre os casos sociais que the pareçam capazes de influir no comportamento dos sentenciados interessados;

V - manter registros de dados atualizados sôbre as possibilidades profissionais dos sentenciados cuja pena esteja em vias de cumprimento;

VI - manter contatos com emprêsas públicas, semi-estatais e particulares, a fim de informar-se sôbre as possibilidades de colocação de egressos da P.C.D.F. [Penitenciária Central do Distrito Federal];

VII - promover a organização legal de associações destinadas a proporcionar assistência social aos sentenciados e presos, aos egressos da P.C.D.F e às suas famílias;

VIII - controlar o funcionamento das associações a que se refere o item anterior;

IX - providenciar sôbre a assistência religiosa aos sentenciados e presos que a solicitarem;

X - fornecer à S. Ad. [Seção de Administração], mensalmente, dados estatísticos relativos às suas atividades. (BRASIL, 1954)

Essas requisições marcam a trajetória do Serviço Social nas prisões, algumas persistem até os dias atuais (seja em relação ao preso, seja em relação ao egresso). Perceba que, no geral, são ações burocráticas (incisos III, V, VIII e X); ações terminais (incisos I, II, VI e VII); ações de controle (inciso IV); e ações de cunho religioso (inciso IX). Ou, nos termos de Santos (1987, p. 61),

"Em relação à prática desenvolvida, o que observamos, através dos
relatórios analisados [...] é que as atividades desenvolvidas
diferenciavam-se em atividades de orientação (conteúdo
comportamental, relacionados ao interno e familiares), atividades de
encaminhamentos (encaminhamentos para dentro da unidade e
recursos da comunidade) e atividades assistenciais (prestação de
serviços concretos, com doações conseguidas no comércio e
indústria)"

Vasconcelos et al (2004) defende que a atuação profissional era voltada para dinamizar o cotidiano do preso e marcadamente assistencialista. Essa marca, para Santos (1987, p. 43-44), construiu uma imagem social de que o Serviço 
Social se resumiria a prestar ajuda material ao preso. Não nos causa estranheza essa confusão, pois o Serviço Social desempenhava ações como realização de festas, cerimônias religiosas, festivais para captação de recursos, controle de cantinas, distribuição de cestas básicas, etc. (VASCONCELOS et al, 2004, p. 01; SANTOS, 1987, p. 43-44).

Na década de 1960, o Serviço Social experimenta avanços e recuos com traços persistentes: em 1962, os profissionais assumiram cargos de direção (SANTOS, 1987; FORTI, 2008). Entretanto, apesar de galgarem o âmbito do planejamento e da gestão, segundo Santos (1987, p. 46), as ações do Serviço Social ainda persistiam em "serviços concretos", ou seja, a ajuda material aos presos e familiares, e poderia ser (como foi) gerida por profissionais de outras áreas; em 1964, com o golpe e a implantação da ditadura empresarial e militar no país, o Serviço Social teve uma dupla perda: (i) a administrativa, retorna ao status de seção; e (ii) técnica, perde sua direção técnica. "O Serviço Social voltou a atuar de forma isolada nas unidades, sem coordenação central, sem programa comum definido por tal coordenação" (FORTI, 2008, p. 240).

De 1964 a 1972, o Serviço Social esteve subordinado às direções das unidades prisionais. Em 1972, houve a criação da Divisão de Assistência Social, cuja preocupação central era a coordenação da assistência religiosa. No período de 1972 e 1975, essa Divisão nunca cumpriu com sua atribuição formal de coordenação do trabalho do Serviço Social (SANTOS, 1987; FORTI, 2008).

Em relação ao período, Lemos (2010, p. 150) defende, inclusive, que durante a ditadura (sobretudo após o ingresso dos presos políticos) competiu ao Serviço Social, para além das atividades comuns, as ações eminentemente de censura, como a avaliação do conteúdo de livros e correspondências postais - o qual ela caracterizou o assistente social também como agente repressor. Porém, desde o início do Serviço Social nas prisões fluminense a profissão esteve vinculada a ações de controle, conforme posto no inciso IV, do artigo 16, do decreto federal $n^{\circ} 35.076$ de 1954 .

É apenas 24 anos após o início das atividades do Serviço Social no sistema prisional do Rio de Janeiro que, por (re) orientação da política penitenciária frente às mudanças econômicas e políticas que se iniciava no país, funda-se a Divisão de Serviço Social (SANTOS, 1987; FORTI, 2008). Para Santos (1987, p. 50), inicia- 
se uma nova etapa da história do Serviço Social penitenciário. Essa assertiva eufórica pode ser compreendida a partir da síntese de Forti (2008, p. 244-245):

\begin{abstract}
“A criação da Divisão de Serviço Social marcou importância face à vinculação, pela primeira vez, da ação desse profissional a um programa geral do Serviço Social na Instituição. Isso favoreceu certa uniformidade na definição de atribuições e no exercício de atividades referentes ao Serviço Social e, em consequência, rumou na direção de uma melhor coordenação técnica para o alcance dos objetivos profissionais pretendidos".
\end{abstract}

Em síntese, para Lemos (2010, p. 147), o período entre 1951 e 1975 corresponde à inexistência de uma instância superior que delineasse, organizasse o trabalho profissional. São características do trabalho profissional, nesse período, segundo Vasconcelos et al (2004, p. 01), a desvinculação de um programa geral e a ausência de uniformidade de atribuições - assim como o assistencialismo é a marca da profissão: "as atribuições do assistente social ainda privilegiavam a ajuda aos presos e familiares através de serviços concretos" (SANTOS, 1987, p. 46).

Em termos de organograma institucional referente ao Serviço Social nas prisões fluminense, ocorreram avanços e retrocessos como síntese das necessidades de racionalização do Estado e das lutas dos profissionais em se afirmar na instituição, conforme o quadro II.

\begin{tabular}{|c|c|c|}
\hline ANO & ESTRUTURA ORGANIZACIONAL & COORDENAÇÃO \\
\hline 1954 & $\begin{array}{c}\text { Serviço de Recuperação Social. Centro de } \\
\text { Serviço Social }\end{array}$ & Médico Victor Messano \\
\hline 1962 & Divisão Cultural e de Serviços Assistenciais. & $\begin{array}{c}\text { Assistentes Sociais e } \\
\text { outros profissionais, como } \\
\text { guardas. }\end{array}$ \\
\hline $\begin{array}{l}\text { Após } \\
1964\end{array}$ & Seção de Assistência Social. & $\begin{array}{l}\text { Vinculada diretamente a } \\
\text { cada Direção de Unidade }\end{array}$ \\
\hline 1972 & Divisão Assistencial & $\begin{array}{l}\text { Advogado de formação } \\
\text { presbiteriana }\end{array}$ \\
\hline 1975 & Divisão de Serviço Social & Assistentes Sociais \\
\hline
\end{tabular}

FONTE: FORTI (2008); SANTOS (1987). COMPILAÇÃO PRÓPRIA.

Santos (1987, p. 53-54) discorre que as principais reivindicações dos assistentes sociais da época eram o de atualização teórica e reestruturação de suas atividades. Ao lado dessas reivindicações, a ação da Divisão de Serviço Social foi igualmente a de requisitar a contratação de novos assistentes sociais. 
De 1975 aos dias atuais, o Serviço Social no sistema prisional do Rio de Janeiro assumiu como parte do trabalho profissional o planejamento, organização e administração de Serviços Sociais e de Unidade de Serviço Social.

Podem-se sintetizar, no quadro III, os marcos históricos relacionados ao trabalho profissional do assistente social nos presídios do Rio de Janeiro:

\section{QUADRO III - MARCOS HISTÓRICOS RELACIONADOS AO SERVIÇO SOCIAL,} ENTRE 1975 E 2007.

\begin{tabular}{|c|c|}
\hline ANO & MARCO HISTÓRICO \\
\hline 1976 & I Curso sobre o Serviço Social no Sistema Penitenciário. \\
\hline 1978 & Responsabiliza-se pelo treinamento de agentes religiosos. \\
\hline 1981 & Supervisões dos assistentes sociais. \\
\hline 1983 & Supervisão Grupal e Individual dos AS por área. \\
\hline 1983 & Reorganização da Coordenação de Estágio. \\
\hline 1983 & Revisão das atribuições profissionais, incluindo o atendimento à família. \\
\hline 1984 & Promulgação da Lei de Execução Penal (LEP). \\
\hline 1986 & $\begin{array}{l}\text { Atribuições definidas no Regulamento do Sistema Penal do Rio de } \\
\text { Janeiro. }\end{array}$ \\
\hline 2002 & Integração da Divisão à Superintendência de Saúde. \\
\hline 2003 & $\begin{array}{l}\text { Promoção de Capacitação Profissional (Fórum de debates e Supervisões } \\
\text { de profissionais e estagiários). }\end{array}$ \\
\hline 2004 & Criação da Coordenação de Serviço Social. \\
\hline $\begin{array}{l}2005- \\
2007\end{array}$ & $\begin{array}{l}\text { Criação de uma Política de Estágio do Serviço Social; } \\
\text { Criação de Comissões de Discussão dos Processos de Trabalho por } \\
\text { Regime Prisional; } \\
\text { Programa de Capacitação Profissional (Fóruns, Minicursos, Palestras, } \\
\text { etc.); } \\
\text { Realização do I Encontro de Assistentes Sociais da SEAP (Set/05 - } \\
\text { Miguel Pereira); } \\
\text { Elaboração da Agenda Política do I Encontro de Serviço Social da SEAP; } \\
\text { Realização de Fórum de Apresentação de TCC: "Um cenário do Sistema } \\
\text { Penal do Rio de Janeiro sob a ótica dos estagiários de Serviço Social”; } \\
\text { Sistematização do Manual de Procedimentos; } \\
\text { Informatização do Credenciamento de Visitantes e Agentes Religiosos; } \\
\text { Criação do Núcleo de Atendimento à Família e Credenciamento de } \\
\text { Bangu; } \\
\text { Realização de Supervisão Profissional Bimestralmente, em grupos e nas } \\
\text { Unidades prisionais. }\end{array}$ \\
\hline
\end{tabular}

FONTE: FORTI, 2008; LEMOS, 2010; BRAVIN, 2013. COMPILAÇÃO PRÓPRIA.

Em relação ao trabalho profissional, entre 1986 e 2010, Lemos (2010, p. 183) expressa que se por um lado o direito penal assegura e legitima o espaço profissional do Serviço Social na execução penal, por outro lado a legislação 
federal pertinente ${ }^{31}$ limita a atuação profissional, remetendo-a a práticas, em geral, pertencentes ao tradicionalismo profissional. Entretanto, para a autora, e sob o suporte da entrevista que ela realizara, o RPERJ ofereceria atribuições mais condizentes com o atual projeto ético-político.

A RPERJ define in verbis o que cabe ao Serviço Social nas prisões do Rio de Janeiro:

Art. 41 - Cabe ao Serviço Social, através do emprego da metodologia específica de sua área profissional:

I - conhecer, diagnosticar e traçar alternativas, junto com a população presa e os egressos, quanto aos problemas sociais evidenciados;

II - ampliar os canais de comunicação dos presos, internos e seus familiares com a administração penitenciária;

III - elaborar relatórios e emitir pareceres se for o caso, em requerimentos e processos de interesse da população carcerária;

IV - interagir junto aos quadros funcionais do sistema penal com vistas a possibilitar melhor compreensão dos problemas sociais da população presa, buscando conjugar esforços para solucioná-los;

$\mathrm{V}$ - interagir com instituições externas no sentido de empreender ações que aproximem recursos diversos para atendimento da população presa, seus familiares, egressos e liberandos, na perspectiva da ação comunitária;

VI - coordenar e supervisionar as atividades dos agentes religiosos voluntários e dos estagiários do serviço social;

VII - integrar os conselhos de comunidade;

VIII - programar com a população presa eventos que propiciem lazer e cultura, interagindo com o serviço educacional;

IX - orientar a população presa e seus dependentes quanto a direitos e deveres legais, especialmente da área previdenciária;

$\mathrm{X}$ - acompanhar o desenvolvimento das saídas para visitas a familiares e para o trabalho externo;

XI - auxiliar os internos na obtenção de documentos.

Um cuidado nos parece necessário na crítica às legislações: ambas as legislações foram elaboradas em período de transição de regime do Estado - do empresarial-militar ao democrático - e de direção social na profissão, cujos marcos são o Congresso da virada, em 1979, o Código de Ética de 1986 e o Currículo Mínimo de 1982.

Outro elemento pertinente é a que na elaboração da LEP (BRASIL, 1984) não houve participação de assistentes sociais, enquanto a RPERJ teve, sobretudo em função do governo do Estado do Rio de Janeiro ter sido eleito pelo sufrágio e sob direção de um democrata, Leonel Brizola (SANTOS, 1987; LEMOS, 2010).

\footnotetext{
${ }^{31}$ Cf. BRASIL, 1984, assim como a seção 2.1. As requisições institucionais ao Serviço Social
} brasileiro. 
Portanto, pode-se dizer que a crítica, ainda que pertinente e necessária, é anacrônica - o que não exclui a sua importância, tampouco a urgência da revisão da LEP e do CPB, agora com ampla participação popular - portanto, para além dos assistentes sociais -, conforme defesa do conjunto CFESS-CRESS. As deliberações de $\mathrm{n}^{\mathrm{o}} 1$ e 2 , do eixo de ética e direitos humanos, no relatório final do $43^{\circ}$ Encontro Nacional do conjunto CFESS-CRESS, realizado em Brasília, em 2014, assim se posicionam:

- Deliberação $n^{0} 1$ “Acompanhar o processo de revisão na LEP tendo em vista a necessidade de estabelecer uma legislação que contemple a garantia de direitos da população carcerária e de suas famílias, de modo a avançar diante da vigente concepção punitivadisciplinar, mantendo o posicionamento contrário à participação de assistentes sociais nos conselhos de comunidade";

- Deliberação $\mathrm{n}^{\mathrm{o}} 2$ "Assumir posicionamento contrário à existência do exame criminológico e favorável à revisão do código penal em ações conjuntas com movimentos de defesa de direitos humanos e outras entidades".

Para Lemos (2010, p. 162-163), o RPERJ avança (i) na definição do profissional e do reconhecimento da profissão como possibilidade de assistir ao preso; (ii) em seu processo de elaboração contou com a participação dos assistentes sociais; e (ii) teria uma orientação do preso como sujeito do processo (referência ao inciso I do artigo 46, que preceitua conhecer, diagnosticar e traçar alternativas, junto com a população presa e os egressos).

Por outro lado, percebe-se a persistência de requisições institucionais históricas e é reconhecida uma atribuição privativa dada pela LEP: em relação à persistência, referimo-nos aos incisos VI (relacionada à assistência religiosa) e VIII (referente às atividades recreativas), e, em relação ao reconhecimento da atribuição privativa, o inciso VII (participação nos conselhos de comunidade), do artigo 46 do RPERJ.

A partir de 2004, com a criação da Coordenação de Serviço Social (CSS) e sua inserção na Subsecretaria Adjunta de Tratamento Penitenciário, em mesmo 
nível hierárquico à segurança (LEMOS, 2010, p. 171-172), Bravin (2013, p. 121) considerou uma vitória em termos de autonomia profissional, relacionada à ingerência técnica e funcional, assim como a capacitação continuada - que amplia seu debate para as dimensões teórico-metodológica e ético-política da profissão, para além do técnico-operativa.

Todo esse quadro de institucionalização do Serviço Social nas prisões, que refletem as determinações históricas relacionadas aos períodos pertinentes, é um breve panorama da realidade concreta em relação às requisições institucionais. Em seguida, busca analisar o trabalho do Serviço Social nas prisões do Rio de Janeiro na contemporaneidade. 


\section{O TRABALHO PROFISSIONAL SOB A ÓTICA DOS ASSISTENTES SOCIAIS DO SISTEMA PRISIONAL DO RIO DE JANEIRO.}

Atravessa necessariamente ao cotidiano profissional nas prisões a mediação pela política social a qual o Serviço Social é requisitado a operar: a política penal, sob a insígnia da LEP e particularmente no Rio de Janeiro o RPERJ - como demonstrado.

Ao operar a política penal, o Serviço Social se legitima enquanto profissão requisitada pela divisão social e técnica do trabalho nos processos de trabalho relacionado às prisões sob o comando do capital (e em conformidade com as regressões sociais impostas pela forma neoliberal de responder a crise orgânica do capital), que é carregada de funções econômicas, políticas e ideológicas as quais direta ou indiretamente são igualmente parte da processualidade da profissão no referido espaço.

Desvelar o trabalho profissional no interior das prisões do Rio de Janeiro sob a ótica daqueles que ali atuam cotidianamente permite aproximações sucessivas de realidade tão presente e ausente da vida social ${ }^{32}$ e da própria profissão ${ }^{33}$.

Assim, parte do trabalho profissional dos assistentes sociais nas prisões do Rio de Janeiro pôde ser situada a partir da pesquisa documental a que se propôs o presente estudo, conforme o percurso metodológico por ora apresentado. $\mathrm{Na}$ análise documental, puderam ser apreendidos temas iniciais que revelaram parte desse trabalho (demandas, respostas, dificuldades, violações e possibilidades), conforme quadro IV.

Para Guerra et al (2016, p. 4), "as atribuições, demandas e requisições da profissão indicam a sua natureza, seu lugar na divisão social e técnica do trabalho, sua funcionalidade ao Estado e suas estratégias de responder à crise do capital".

Assim, as respostas dos questionários que se relacionam às demandas, respostas às demandas, dificuldades, violação de direitos e possibilidades de trabalho revelam mais do que os processos e procedimentos da atuação

\footnotetext{
${ }^{32}$ Refere-se ao processo que Davis (2018) considera próprio das prisões: ao mesmo tempo em que elas são presentes devido ao seu poder dissuasivo - a tal da prevenção geral negativa -, elas são ausentes, uma vez que existiriam poucos esforços, inclusive dos movimentos anticapitalistas, por mudanças em seu interior ou mesmo sua abolição.

${ }^{33}$ Conforme indicação no percurso metodológico há indícios de escassez de produções acadêmicas no Serviço Social sobre as prisões.
} 
profissional: expõem concepções de sociedade, projetos de profissão, valores, habilidades, conhecimentos, atitudes e afins.

\begin{tabular}{|c|c|}
\hline QUADRO IV - DOS EIXOS E TEMAS DA ANÁLISE DOCUMENTAL. \\
\hline EIXO & TEMA \\
\hline Demandas & Demandante \\
\cline { 2 - 2 } & Demanda \\
\hline Respostas às demandas & Ações Burocráticas \\
\cline { 2 - 2 } & Ações Profissionais \\
\cline { 2 - 2 } & Conhecimento \\
\hline Dificuldades & Construmentos e técnicas \\
\cline { 2 - 2 } & Correlação de frabalho Fças \\
\hline Violação de direitos & Subalternidade da Profissão \\
\cline { 2 - 2 } & Agente violado \\
\hline & Anobservâtrio \\
\hline Possibia da lei \\
\cline { 2 - 2 } & Privação de Serviços \\
\cline { 2 - 2 } & Articulação Intraprofissional \\
\cline { 2 - 2 } & Articulação Política \\
\hline
\end{tabular}

FONTE: Apêndice de CRESS/RJ (2018). Compilação Própria.

\subsection{Demandas ao Serviço Social nas prisões do Rio de Janeiro.}

O termo demanda significa "ação ou efeito de demandar, de buscar, de procurar; necessidade de alguma coisa; ação de exigir, reivindicar, de demandar esforços para recuperar algo que pertence à outra pessoa; reivindicação" (DEMANDA, 2019). Pode-se dizer que a demanda expressa a capacidade teleológica dos seres sociais em relação à satisfação de suas necessidades, em que as variáveis empíricas manipuladas pelo Serviço Social são vistas como meios/instrumentos de objetivação.

Essas variáveis empíricas estão inseridas em uma dupla dinâmica: são determinadas pelas políticas sociais, que são formas de responder à "questão social" (resultante da realidade concreta); e são (re) orientadas pela consciência subjetiva dos profissionais (produto teórico e prático do projeto profissional coletivamente construído).

Assim, os processos de trabalho são atravessados pela "questão social" pois o conflito entre capital e trabalho determinam as necessidades sociais a serem respondidas e o modo como se enfrenta, como uma espécie de consenso tênue e, 
portanto, conflituoso e contraditório entre as necessidades do estágio vigente de acumulação e valorização de capital e o atendimento de interesses do trabalho - e pela direção social e política assumida pelos profissionais.

Portanto, quando se depara com uma demanda, o profissional deve atentarse quanto ao seu demandante e o conteúdo de classe que a demanda carrega.

Quando perguntados acerca de "quais são as demandas" que recebem nas prisões, percebe-se um esforço dos assistentes sociais na distinção entre possíveis demandantes. A demanda, segundo os profissionais, se originaria dos presos, de seus familiares e da instituição. Exemplo que melhor ilustra são as respostas a seguir:

\footnotetext{
"Direção da unidade prisional" (AS 01)

"Atendimento a solicitações de instituições (ex: família acolhedora CREAS)" (AS 06)

"Família (aux. Reclusão, reconhecimento de paternidade, registro de criança, visita especial, visita intima, visita, questões referentes ao interno)" (AS 13)

"Interno (aux.reclusão, cancelamento e reconsideração de carteira, visita especial, visita intima, exame criminológico, questões referentes a família, avaliação)" (AS 13)
}

Esse esforço de distinção parece ser insuficiente quando se relaciona aquilo que foi percebido como demanda e ao conteúdo das requisições institucionais no bojo da LEP e da RPERJ. Portanto, há um esvaziamento do conteúdo de classe das demandas. Sistematizadas as respostas referentes às demandas, pôde-se agrupa-las em:

- Situação Jurídica;

- Visita Excepcional;

- Visita entre presos;

- Visita íntima;

- Cancelamento e Reconsideração de cancelamento de carteira de visitante;

- Registros de nascimento e reconhecimento de paternidade;

- Ingresso de crianças;

- Movimentação de Pequenos Valores;

- Previdência/Auxílio Reclusão;

- Documentação Civil;

- Assistência Religiosa;

- Comissão Técnica de Classificação;

Os assistentes sociais, assim, apreendem as demandas reduzidas à requisição institucional, com exceção de uma resposta: "Por liberdade - 
conhecimento da situação jurídica" (AS 01), cuja ação seria apropriadamente demanda da assistência jurídica - que dada às dificuldades de se aproximar da Defensoria Pública os presos orientam sua busca por tais ações ao Serviço Social - o que demonstra ao mesmo tempo uma dupla dinâmica: (a) as dificuldades do acesso à assistência jurídica; e (b) a sintonia com a atual fase de acumulação e valorização do capital: desespecialização, desprofissionalização, dessubjetivação (GUERRA et al 2016).

As visitas constituem direitos do preso previsto no inciso X, do artigo 43, da LEP, e sua suspensão ou restrição estão associadas a "ato motivado do diretor do estabelecimento". Igualmente, o comportamento tem sido requisito para o próprio acesso (hierarquizado a partir de um índice de aproveitamento, que se altera em decorrência da disciplina ${ }^{34}$ ).

Esse direito recebe no discurso oficial a proposta de auxiliar a prevenção especial positiva (ressocialização), configurando a família como principal estrutura de redenção do preso. Em sentido semelhante, tem-se a proposta das Regras de Nelson Mandela (ONU, 1955) que inclui a visita no âmbito da reinserção social - ou, em seus próprios termos, de contato com o mundo exterior.

Em síntese, segundo Duarte (2015, p. 73), “as leis, tanto as federais quanto as estaduais, não suscitam dúvidas em relação às visitas comuns realizadas por familiares e amigos aos presos: são direitos dos internos, essenciais à sua 'ressocialização' e ao contato com o mundo exterior'.

Na perspectiva crítica, preservar ou reconstituir o convívio sociofamiliar a partir da visita, seja com conjugue, companheiro, familiar ou amigo, esteja à pessoa em liberdade ou igualmente reclusa, configura-se como satisfação de necessidade do ser social. Portanto, um direito humano, incluso igualmente nas políticas sociais em geral.

\footnotetext{
${ }^{34}$ De acordo com o Artigo 20 do RPERJ: o índice de aproveitamento dar-se-á: I - no conceito excepcional, após seis meses de permanência ininterrupta no conceito excelente; II - no conceito excelente, após seis meses de permanência ininterrupta no conceito ótimo; III - no conceito ótimo, após sei meses de permanência no conceito bom; IV - no conceito bom, após seis meses de permanência ininterrupta no conceito neutro; $\mathrm{V}$ - no conceito neutro, durante o período probatório e após o término do prazo de conceito negativo; VI - no conceito negativo, em razão de sanção disciplinar. $\S 1^{\circ}$ - O período probatório de ingressando é de seis meses. $\S 2^{\circ}$ - Aplicada a sanção de rebaixamento de classificação a quem estiver no conceito negativo, o prazo para ascender ao conceito neutro é de seis meses, contado a partir da aplicação da última punição.
} 
As formas de visitas, ou seja, de convivência sociofamiliar nas prisões do Rio de Janeiro são divididas em quatro: excepcional; comum; entre presos; e íntima.

Anteriormente à visita em si, ocorre o processo de cadastramento. Esse processo deixou de ser requisição ao Serviço Social ${ }^{35}$, tornando-se função administrativa - não mais técnica. Sua operacionalização, desde 2018, tem sido realizada no Rio de Janeiro pelo Departamento de Trânsito do Estado do Rio de Janeiro (DETRAN), em específico pela Diretoria de Identificação Civil (DIC), responsável igualmente pela emissão da carteira de visitantes ${ }^{36}$. Além do DETRAN, compete à própria SEAP o controle de entrada nas unidades prisionais.

Uma marca histórica da visitação era a revista vexatória. De acordo com a ONU (1955), é o “o ato de despir e de inspecionar partes íntimas do corpo". No Rio de Janeiro, a revista vexatória foi abolida em 2015, a partir da Lei Estadual ${ }^{\circ}$ 7.010 de 25 de maio de 2015. Uma grande vitória da luta contra o tratamento desumano e degradante, sobretudo às mulheres que visitavam os presos.

Faz-se referência à revista vexatória por ela ter sido historicamente um impeditivo real da preservação ou reconstituição do convívio sociofamiliar, cumprindo explicitamente as funções políticas (controle e disciplina) e ideológicas das prisões (associação ao medo). Camargo (2007, p. 241) expressa que:

Fatores como "medo", "vergonha", "covardia" também interferem para fragilizar o vínculo. Notem a preocupação de uma outra companheira, durante orientações fornecidas por telefone, sobre as normas institucionais para realização de visita: "É verdade que a gente tem que tirar toda a roupa, ficar 'pelada'? (...)".

Nesse contexto, a visita comum é operada por setores administrativos e de segurança da SEAP e mesmo externo à secretaria - no caso, o DETRAN. Por outro lado, as visitas íntimas, excepcionais e entre presos são requisições ao Serviço Social, no Rio de Janeiro sob o parâmetro de Resolução própria da SEAP.

\footnotetext{
35 “Até meados de 2013, o pedido da carteirinha era realizado na Divisão de Atendimento à Família e Credenciamento, localizado próximo ao portão central de entrada do Complexo de Gericinó. Inicialmente, a pessoa era encaminhada para uma espécie de triagem em que se analisava a documentação trazida ao processo de credenciamento. Posteriormente, a pessoa era conduzida aos assistentes sociais que preenchiam a ficha de credenciamento com os dados pessoais do visitante" (DUARTE, 2015, p. 104).

${ }^{36}$ Cf. Decreto Estadual no 46.404 de 28 de Agosto de 2018.
} 
A visita íntima é a que mais incita questionamento, seja da sociedade - que pondera sua existência (fundamentado a partir da função ideológica da prisão, visto que "maus" cidadãos não deveriam ter "regalias") -, seja do Serviço Social em relação ao seu papel burocrático e controlador (função política das prisões) no processo de visita íntima.

Lemos (2010, p. 186 - grifos originais) sintetiza esse procedimento de trabalho do assistente social atualmente:

A visita íntima é organizada e controlada pelo Serviço Social. O acompanhamento é feito através de uma planilha, chamada de mapa, onde fica registrada a frequência dos casais. Geralmente, quando o casal tem três faltas consecutivas, sem justificativa o mesmo é "cortado do mapa" e ficará aguardando nova vaga para voltar a gozar da visita.

Observe que o Serviço Social, por requisição institucional, tem o controle sobre a vida sexual do preso: determina dia, horário e suspensão da relação (LEMOS, 2010, p. 186). Houve época que todo o processo era controlado pelo profissional (com exceção da concessão do direito). Duarte (2015, p. 103-104) relata que, na década de 1970, ao Serviço Social competia a definiç̧ão do lugar improvisado para a visita íntima, a organização da fila e o controle do tempo (previsto em uma hora por casal). A autora assim descreve o processo:

\footnotetext{
Em um dia de visita íntima, o preso preparava o lençol e a toalha a serem utilizados por ele e sua parceira durante o encontro. Formava-se uma fila de internos diante da porta do quarto onde eram realizadas as visitas. Em outro ponto da unidade, era constituída outra fila com as companheiras dos presos. Os assistentes sociais organizavam a fila da seguinte maneira: certo preso e sua respectiva companheira compunham o primeiro lugar da fila e assim sucessivamente. Na porta do quarto havia uma campainha e quando o tempo estipulado para a visita terminava, cerca de uma hora, o assistente social a tocava, avisando sobre a necessidade de o casal liberar o quarto para os próximos da fila. Esse tipo de procedimento só terminava quando findava o horário de visita do dia e todos os detentos previstos no "mapa" de visitação da unidade tinham se encontrado com suas companheiras (DUARTE, 2015, p. 104).
}

Por volta dos anos de 1980, como parte do processo de racionalização do Estado, surgem os "parlatórios" - locais apropriados para a visita íntima. Duarte (2015, p. 105) expressa que concomitantemente emergem as "celas do amor", igualmente denominada de "jupirão". Trata-se de um período em que a visita 
íntima tinha a previsão de ocorrer entre duas e três horas, mas que era comum o pernoite da pessoa visitante na cela do preso, sendo regulamentada em 1987 pela Portaria 648 do DESIPE. A partir desse período o Serviço Social passaria a organizar o processo tal como supracitado - a partir de Lemos (2010).

No entanto, em 1988 inicia-se uma política de recrudescimento penal sobre as famílias com a imposição de intervalo de dois anos entre o cancelamento e o cadastramento de novo companheiro (alterada para seis meses no início dos anos de 1990). Outras medidas foram adotadas, tais como a restrição de cadastro de pessoa amiga para apenas um preso; e condicionalidades em relação aos alimentos conduzidos às unidades prisionais pelos familiares. O discurso oficial da retribuição reforça a punição, configurando-se mais como vingança, que afeta o direito à convivência sociofamiliar (nas suas quatro formas, sobretudo a visita excepcional).

Esse contexto mostra que as relações sociofamiliares na prisão são tuteladas e que ao Serviço Social se apresentam como demandas burocráticas (impostas como requisição institucional), mas que na realidade concreta carregam conteúdos contraditórios, com variáveis entre o direito ao convívio sociofamiliar, o controle e a disciplina.

O processo de cancelamento e reconsideração de carteiras demonstra com maior transparência o caráter burocrático dessa requisição (que é reconhecida pelos profissionais como demanda) ao Serviço Social: o preso procura o setor da profissão para assinar um documento em que cancela ou reconsidera após seis meses àquela carteira cancelada. Ao Serviço Social compete o trânsito desse documento entre o usuário e os setores administrativos da prisão.

Processos semelhantes são os de Registros de nascimento e reconhecimento de paternidade; Ingresso de crianças; e Movimentação de Pequenos Valores, cujo papel do Serviço Social é a informação acerca dos documentos e o trânsito documental entre a família e o preso, passando pela direção da unidade prisional e o setor administrativo que elabora o atestado de permanência $^{37}$ - e quando se trata do reconhecimento de paternidade também passa pela Defensoria Pública.

\footnotetext{
${ }^{37}$ Documento de fé pública que comprova para devidos fins a privação de liberdade de um sujeito.
} 
A demanda previdenciária/auxílio reclusão não difere das supracitadas em relação ao processo burocratizado nas prisões, mas sua existência tem sido questionada a partir da função ideológica da prisão. Segundo Chies e Passos (2012, p. 274), a partir de um email, em 2009, que deturpava as informações sobre o auxílio-reclusão, ele ficou popularmente conhecido como "bolsa-bandido".

Dentre outras questões, Chies e Passos (2012) buscaram identificar as representações sociais do auxílio-doença na sociedade brasileira. Em síntese, o resultado da pesquisa foi:

Um panorama compreensivo da repulsa social que recai sobre o instituto, sendo esta elaborada sobretudo através do estabelecimento (ou permanência histórica) de uma fronteira que separa o bem e o mal a partir dos estereótipos do bom e do mau, das caricaturas do "cidadão de bem" e do "homem infame", as quais nos conduzirão ao digno de cidadania e ao indigno, o outro, o estranho e, por fim, ao inimigo, passível inclusive de eliminação (CHIES e PASSOS, 2012, p. 285).

Em geral, o Serviço Social se apresenta como "porta de entrada", informando as documentações necessárias e os trâmites dos processos, cuja resposta final quase sempre compete ao diretor da unidade prisional, requerida pelo assistente social a partir da procura do usuário.

Segundo Iamamoto (2004, p. 100),

\begin{abstract}
Do ponto de vista da demanda, o assistente social é chamado a constituir-se no agente intelectual de "linha de frente" nas relações entre instituição e população, entre os serviços prestados e a solicitação desses mesmos serviços pelos interessados. Dispõe do poder, atribuído institucionalmente, de selecionar entre os que têm ou não direito de participar dos programas propostos, discriminados, entre os elegíveis, os mais necessitados, devido à incapacidade da rede de equipamentos sociais de atender a todo público que, teoricamente, tem direito a eles.
\end{abstract}

No entanto, a particularidade das prisões imprime traço peculiar ao trabalho profissional em relação à demanda. Permanece o assistente social como o profissional da "linha de frente", mas seu poder institucional é o de distinguir entre os que não têm direito e os que potencialmente têm direitos, visto que a determinação final compete a outros agentes, como o juiz ou o diretor da unidade prisional, configurando caráter burocrático e pontual ao trabalho profissional, conforme determina o RPERJ, mas em especial a LEP.

Assim, percebe-se que as requisições postas pela instituição são 
excessivamente burocráticas, envolvendo extensa documentação, em especial requerimentos - muito próximo ao exigido pelo artigo 41, inciso III do RPERJ: "III - elaborar relatórios e emitir pareceres se for o caso, em requerimentos e processos de interesse da população carcerária". São exigências, inclusive, de relato e permissão final (em geral, mera assinatura) da direção da unidade, conforme o artigo 23, inciso II da LEP: "II - relatar, por escrito, ao Diretor do estabelecimento, os problemas e as dificuldades enfrentadas pelo assistido".

Esse movimento reducionista (demandas que são requisições) demonstra não mero desconhecimento individual ou confusão profissional, mas expressa igualmente o próprio caráter da instituição-prisão, que conduz impositiva e arbitrariamente o cotidiano profissional. Ela conforma a própria demanda do usuário e, sobretudo, limita a autonomia profissional, como em poucas instituições.

Dantas e Pereira (2009) expressam o caráter próprio das prisões como custódia que, embora demonstre parte das funções da instituição (precisamente sua função política), revela um cotidiano de juízos morais, disciplinador, vigilante e com recurso usual da violência, cujas relações de custódia são formadas por uma divisão funcional, burocrática e hierárquica - que decerto conformam particularidade ao trabalho profissional, impondo, senão as mesmas técnicas, limites às ações profissionais e (quase) restrições ao campo da burocracia e das respostas imediatas.

Essas características do trabalho profissional nas prisões do Rio de Janeiro em relação às demandas reforçam a ideia do direito como benefício. Segundo Iamamoto (2004, p. 97),

Ao fazerem isso, recuperam e falsificam o conteúdo de classes [das demandas que, transformadas em reivindicações por melhores condições de vida, foram apropriadas pelas instituições e transformadas em benefícios indiretos a partir de uma estrutura burocrática, controlada diretamente pelo Estado]. Trata-se de buscar deslocar as contradições do campo explícito das relações de produção para absorvê-las e controlá-las nos canais abertos no nível do aparelho do Estado. A distribuição dos "benefícios sociais", sob a capa paternalista e benfeitora do Estado ou do empresário, funciona geralmente acoplada a um discurso de cooperação entre as classes, de ajustamento psicossocial do trabalhador, elementos básicos à interiorização das relações vigentes sob a hegemonia do capital. 
Nas prisões, essa distribuição ocorre sob os discursos oficiais - que igualmente propõem à conciliação de classes e o ajustamento do preso (o ideário reformista), assim como são mediadas pelo critério de elegibilidade central: o comportamento, a disciplina.

Assim, os serviços sociais (ressignificados como "benefícios") se constituem contraditoriamente (e, portanto, intrínseco) a partir de uma dupla dimensão: (i) são meios de socializarem o controle e a disciplina (a função política das prisões) no processo de reprodução material e espiritual da força de trabalho excedente ali reclusa, cujo principal critério de elegibilidade é o comportamento, isto desde o direito à progressão de regime aos serviços sociais, assim como à própria liberdade - ainda que condicional; (ii) embora sejam instrumentos de subordinação, cuja gestão se restringe ao Estado (isto é, sem participação popular), são mecanismos necessários (e às vezes vitais, como as diferentes formas de visitas e o auxílio reclusão) à reprodução material e/ou espiritual dos usuários.

Nesse sentido, quando se limita demanda à requisição institucional, além de operar o esvaziamento do conteúdo de classe, demonstra um trabalho profissional cristalizado e que se propõe a fortalecer as metas do capital, a partir das exigências do mercado de trabalho, em detrimento do projeto profissional hegemônico que se propõe construir uma legitimidade profissional com quem usa os serviços, isto é, com a classe trabalhadora.

Inclusive, Iamamoto (2004, p. 104) adverte:

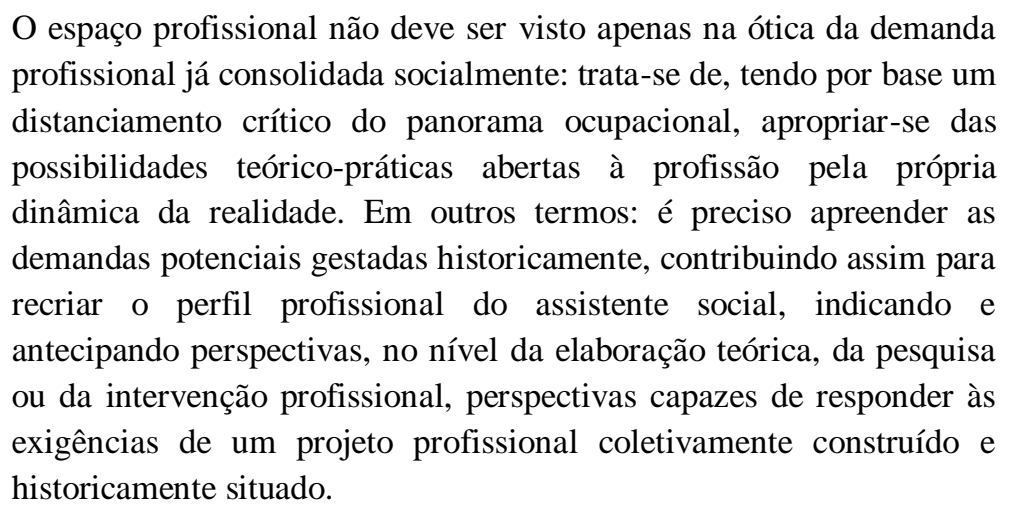

Portanto, a relação que nos parece central não é algo meramente técnico, mas essencialmente político, que envolve projetos de sociedade e de profissão e que expressam os antagonismos de classes presentes na vida social como um todo. 
Esse trabalho profissional retratado pelos assistentes sociais remonta aos primórdios da profissão no próprio interior das unidades prisionais. Santos (1987, p. 63-64) resumiu processo semelhante ainda na década de 1980:

O próprio Assistente Social reforçava a imagem de um serviço que 'apenas' prestava assistência, em razão dos seguintes fatores:

- Devido ao atendimento em massa, sobressaía, como resultado de sua ação, a prestação de serviços concretos;

- A clientela, que sempre viu o Assistente Social como a pessoa que resolvia seus problemas e os de seus familiares, após ter satisfeito sua necessidade imediata, não mais procurava o serviço. Também não era mais procurado porque havia centenas de internos à espera de um atendimento;

- Estando a clientela sempre necessitada de informações a respeito de sua situação jurídica (em geral, requerimentos que faziam, pedindo comutação de pena, andamento em outros processos que ainda estavam e, julgamento, o alvará que não havia chegado, etc.) apelava para o Serviço Social que, erradamente, tomava as providências que, na realidade, competiam à outra Divisão do próprio DESIPE. O Assistente Social assumia atribuições que não eram de sua competência, por não estarem sendo desempenhadas por quem de direito;

- O campo de trabalho, por sua própria natureza, apresentava dificuldades para se colocar em prática alguns dos princípios do Serviço Social. O Assistente Social, ao desenvolver algum trabalho mais técnico, era mal interpretado. Eram tantas as barreiras a serem transpostas que o profissional voltava a atua numa linha puramente assistencialista.

Como condição histórica, a alternativa para romper com essa imagem social (assistencialista, burocrática e pontual) e ultrapassar as requisições institucionais é coletivamente alinhar-se aos movimentos sociais e populares em perspectiva anticapitalista, antirracista e abolicionista penal, senão as respostas profissionais expressarão a burocracia, a hierarquia, o controle, a disciplina, a coerção e o consenso próprio dos processos de trabalho na prisão. Posto isso, no próximo item pretende-se abordar as respostas profissionais a essas demandas.

\subsection{Resposta profissional às demandas postas.}

Reconstruir as demandas consolidadas e reconhecer novas são desafios postos ao Serviço Social, que expressam a intencionalidade dos profissionais, seus valores e conhecimentos. 
Assim, na análise do conteúdo dos questionários, percebeu-se que as requisições institucionais (demandas consolidadas) revelam características próprias das funções da prisão, sobretudo o controle e a disciplina.

Assim, as respostas profissionais às demandas consolidadas são agora o eixo temático. A partir da indagação como você responde a essas demandas, têmse temas de análise de conteúdo. Fragmentos a seguir demonstram que as respostas profissionais envolvem ações burocráticas que se esgotam em si mesmas:

"Elaboração de documentos" (AS 01)

"Realizando Comunicações Internas para Direção constando as solicitações" (AS 06)

"Atendimento telefônico" (AS 06)

"Elaboração de documentos que são encaminhados a subsecretaria de tratamento penitenciário, apresentando atual quadro de profissionais (déficit) em relação à crescente demanda do Serviço Social nas Unidades Prisionais" (AS 11)

Atestado de permanência. (3 em 3 meses para INSS) (AS 13)

Entre as funções administrativas ${ }^{38}$ e a documentação (enquanto instrumental técnico) existe o assistente social, trabalhador assalariado que pode mobilizar a documentação em direção alinhada ao projeto ético-político, ressignificando sua importância (ao ultrapassar seu caráter burocrático de controle e disciplina) e valorizando a própria profissão (ao produzir informações e conhecimentos).

Ou nos termos de Marcosin (2012, p. 69 - grifos originais), a documentação:

Pode até ser um simples "roteiro de papéis a serem preenchidos e organizados" para determinadas concepções, perpetuando o seu caráter controlista e burocrático. Mas, não é dessa forma que a estamos tratando aqui, e sim, como um instrumental técnico que possibilita organizar e veicular informações, bem como produzir informações e conhecimento. Ela contém os dados da realidade, que são material de análise do assistente social e que se transformam em informações úteis à população usuária do Serviço Social, sobre ela e a realidade e, também, sobre a própria profissão. A criação e transmissão de informações e mensagens é parte integrante do trabalho e tem correspondência com a concepção teórico-

\footnotetext{
${ }^{38}$ Por exemplo, o atendimento telefônico não é de competência profissional, pois como redigido pelo assistente social demonstra uma espécie de passividade no ato e não de atividade, como algo do tipo de busca ativa para localização de familiares, e menos ainda a elaboração de atestado de permanência, algo que é próprio do setor administrativo das unidades prisionais.
} 
metodológica que adotamos e com o contexto sócio-histórico. Como tal, porta ideologia, embora nem sempre seja algo consciente.

Guerra et al (2016, p. 10-11 - grifos originais) perceberam que mesmo nas produções acadêmicas do Serviço Social (anais do CBAS e do ENPESS e nas teses e dissertações) há o equivoco de desconsiderar a dimensão investigativa da profissão, ou nos termos dos autores "ausência sempre sentida é a de não reconhecimento das atividades de pesquisa como atribuição, mantendo a concepção equivocada de que pesquisa é uma atribuição restrita à academia".

Parte das ações burocráticas, assim, podem ser ressignificadas (ainda que seu caráter permaneça) quando observadas criticamente: podem ser pontos de partida e chegada do cotidiano prisional na linha da sistematização da prática, assim como de reflexões teóricas ou mesmo resultados de pesquisa. E, alinhadas a posicionamentos éticos e políticos construídos coletivamente pela categoria profissional, contribuírem em processos de ampliação da atuação profissional e das lutas sociais em torno dos direitos da população usuária, processos que podem influenciar na autonomia relativa do assistente social.

Outro tema derivado da análise de conteúdo se refere à dimensão técnicooperativa em especial a dimensão meramente instrumental e procedimental (ainda que não exclusivamente). Dois temas, assim, se destacam no âmbito das respostas profissionais: instrumentos e técnicas; e conhecimento.

Observação pertinente se faz ao processo próprio de legitimidade e de reconhecimento profissional na instituição, que imprimem ao Serviço Social uma associação entre respostas profissionais e os próprios instrumentos e técnicas, conforme explicitado abaixo:

\footnotetext{
"Através de relatórios, reuniões, atendimentos grupais e individuais, pareceres" (AS 05)

"Domínio do instrumental técnico operativo e colocar como instrumento de emancipação" (AS 10)

"Utilizando o instrumental utilizado pela profissão para interlocução na garantia de direitos". (AS 18)
}

Assim como uma imposição de instrumentos e técnicas que conformam uma dinâmica de trabalho em que os profissionais assimilam o instrumento (parecer social) como demanda propriamente. Perceba abaixo: 
"Elaboração de relatórios de gestão e de inspeção no âmbito do SESO, tendo em vista serem em nível institucional capacitação de educação continuada a assistentes sociais e estagiários" (AS 02).

"Relatórios/pareceres" (AS 04)

"Relatório social para compor exame criminológico" (AS 05)

"Entrevistas e relatórios sociais (exames criminológicos e comissão de classificação técnica)" (AS 07)

Percebe-se não qualquer associação ou assimilação, mas algo relacionado à redução da própria profissão à dimensão técnico-operativa - movimento próprio do metodologismo que caracterizou o início da profissão. A própria requisição institucional pelo exame criminológico, em consonância aos artigos 34 e 83 do CPB, apesar da controvérsia da jurisprudência do STF, impõe uma dinâmica de trabalho que beira à crise de identidade profissional - de tão impositiva e contrária à direção social e política da profisssão.

Esse processo de associação ou assimilação entre demandas (ou respostas a essas demandas) e instrumentos e técnicas condensam na mesma ação: (a) as contradições da estrutura econômica sob os ditames do capital e sua forma típica de trabalho (trabalho assalariado, alienado e explorado), assim como as práticas e instituições sociais que surgem para dar legitimidade ao capital; e (b) as intencionalidades dos sujeitos históricos e concretos envolvidos nos processos de trabalho (propriamente o modo de pensar as demandas e respostas profissionais e a própria profissão).

Acontece que as intencionalidades dos profissionais estão igualmente difusas para eles próprios ${ }^{39}$. Em que o caso emblemático é do assistente social denominado de "AS 01", conforme o quadro V. Na mesma proporção que ele considera a participação em eventos e o conhecimento de legislações como respostas as demandas, indica como dificuldade a ausência de política penitenciária, sugerindo que a realidade prisional tal como ela é não seja parte de um projeto societário, que carrega o controle e a vigilância sobre a superpopulação relativa, sua associação às classes perigosas e a rentabilidade econômica que pode derivar das prisões e da população encarcerada como partes desse projeto de sociedade.

\footnotetext{
${ }^{39}$ Por intencionalidade difusa não se refere à intencionalidade da profissão, que segundo Netto (2007a, p. 112-113) é historicamente reformista e no âmbito ético-moral. Mas à dimensão humano-genérica do ser social que busca responder suas carências (materiais ou espirituais) a partir de finalidades e projeções - que, no caso em questão, expressam ecleticamente concepções de mundo.
} 


\title{
QUADRO V - FRAGMENTOS DE RESPOSTAS EM RELAÇÃO AOS EIXOS DE RESPOSTAS ÀS DEMANDAS, DIFICULDADES, VIOLAÇÃ̃O DE DIREITOS E POSSIBILIDADES DE TRABALHO.
}

\begin{tabular}{|c|c|c|c|c|}
\hline PROFISSIONAL & RESPOSTAS & DIFICULDADES & VIOLAÇÃO & POSSIBILIDADE \\
\hline AS 01 & $\begin{array}{c}\text { Participação de } \\
\text { eventos/reuniões } \\
\text { Conhecimento } \\
\text { de }\end{array}$ & $\begin{array}{c}\text { Falta de política } \\
\text { penitenciária. } \\
\text { regulamentação } \\
\text { (portarias / } \\
\text { resoluções, etc). }\end{array}$ & $\begin{array}{c}\text { Falta de } \\
\text { o do que já } \\
\text { está } \\
\text { estabelecido. }\end{array}$ & $\begin{array}{c}\text { Maior visibilidade } \\
\text { do papel do } \\
\text { profissional no } \\
\text { espaço } \\
\text { institucional. }\end{array}$ \\
\hline
\end{tabular}

FONTE: CRESS/RJ (2018). COMPILAÇÃO PRÓPRIA.

Por outro lado, ainda no âmbito da dimensão técnico-operativa, exposta no eixo das respostas profissionais, têm-se o conhecimento como tema. Observe alguns exemplos quanto ao conhecimento:

Pensar a realidade institucional à luz da teoria social crítica ajuda a compreender o exercício profissional nesse campo profissional. (AS 03)

Apropriação do conhecimento e enfrentamento dos obstáculos através da discussão e do diálogo propositivo interno e externo. (AS 07)

Aprimoramento e aperfeiçoamento profissional. Além de interlocução com órgãos que respaldem a categoria no seu fazer profissional. (AS 18)

Percebe-se a reafirmação do conhecimento (adquirido ao longo do processo formativo e da educação continuada) como processo para além da interpretação da realidade, mas assumindo-o como meio de trabalho. Ou nos termos de Iamamoto (2011, p. 62 - grifos originais),

\begin{abstract}
A noção estrita de instrumento como mero conjunto de técnicas se amplia para abranger o conhecimento como um meio de trabalho, sem o que esse trabalhador especializado não consegue efetuar sua atividade ou trabalho. As bases teórico-metodológicas são recursos essenciais que o assistente social aciona para exercer o seu trabalho: contribuem para iluminar a leitura da realidade e imprimir rumos à ação, ao mesmo tempo, em que a moldam. Assim, o conhecimento não é só um verniz que se sobrepõe superficialmente à prática profissional, podendo ser dispensado; mas é um meio pelo qual é possível decifrar a realidade e clarear a condução do trabalho a ser realizado. Nessa perspectiva, o conjunto de conhecimentos e habilidades adquiridos pelo assistente social ao longo do seu processo formativo são parte do acervo de seus meios de trabalho.
\end{abstract}

Assim, Santos, Filho e Backx (2017, p. 29) exprimem que o trabalho profissional compreende uma relação de totalidade com as dimensões teóricometodológico, ético-político e técnico-operativo, porém cada dimensão 
expressaria uma autonomia relativa entre elas, assim como é fundamental não reduzir a dimensão técnico-operativa ao manuseio de instrumentos e técnicas estabelecendo constante articulação e organicidade com as demais dimensões, em que o conhecimento é exemplar nessa articulação.

Essa associação ou assimilação seja da demanda, seja da resposta profissional com os instrumentos e técnicas reforçam, além do metodologismo histórico na profissão, a forma aparente da profissão para o conjunto da sociedade, assim como para alguns profissionais.

Superar a forma aparente pela qual a profissão é conhecida e reconhecida se apresenta como desafio que ultrapassa o Serviço Social nas prisões do Rio de Janeiro: trata-se de algo estrutural de toda a categoria profissional, das mais diversas políticas sociais. Santos, Filho e Backx (2017, p. 29) sugerem como proposta o pensar sobre o trabalho, sistematiza-lo e qualificar o manejo dos instrumentos e técnicas.

As autoras defendem que não se pode confundir os instrumentos e técnicas com as respostas profissionais em si (e igualmente com as demandas). Propõem que os instrumentos e técnicas sejam ferramentas que efetivam as intencionalidades dos profissionais e imprimam a direção social das ações predefinidas. Portanto, a utilização de instrumentos e técnicas teria relativa autonomia de sua origem e finalidade anteriores - processo que nas prisões requer um cuidado em especial quanto ao exame criminológico, cuja existência é questionada pelo projeto profissional do Serviço Social exatamente por sua origem e finalidade.

Nesse contexto, apreender os elementos constitutivos da dimensão técnicooperativa demonstra a ultrapassagem de sua limitação aos instrumentos e técnicas:

\footnotetext{
A dimensão técnico-operativa é constituída dos seguintes elementos: as estratégias e táticas definidas (Por Quem? Onde? Quando? Como?) para orientar a ação profissional [entendida como expressão do 'fazer profissional: orientar, encaminhar, avaliar, estudar, planejar e outras ações previstas como competências e atribuições na legislação profissional, que é desenvolvido em um serviço prestado pela instituição que pode ter variadas formas'], os instrumentos, técnicas e habilidades utilizadas pelo profissional, o conhecimento procedimental necessário para a manipulação dos diferentes recursos técnico-operacionais, bem como a orientação teórico-metodológica e ético-político dos agentes profissionais (SANTOS, FILHO e BACKX, 2017, p.31 - grifos originais).
} 
Ainda no eixo das respostas profissionais, encontrou-se o tema a que nos referimos de ações profissionais. Em síntese, são ações profissionais do assistente social nas prisões do Rio de Janeiro as descritas abaixo:
a) Atendimento;
b) Acompanhamento;
c) Orientação;
d) Encaminhamento;
e) Articulação (redes e outros profissionais);
f) Planejamento (gestão e supervisão)

Esses elementos são mobilizados para responder as demandas dos usuários conformadas pela instituição. Percebe-se ênfase das ações profissionais no atendimento terminal, como sintetiza bem o fragmento a seguir:

\begin{abstract}
"Atendimento a família (registro da prole, reconhecimento de paternidade, abertura de processos de visita íntima)" (AS 03)

"Atendimento aos presos (exame criminológico, processos de visita íntima etc)" (AS 03)
\end{abstract}

Esse foco no indivíduo ${ }^{40}$ e o atendimento pontual compreendem características de requisição à profissão para controle. Iamamototo (2004, p. 101) expressa essa característica da demanda que conforma a resposta profissional:

\begin{abstract}
Ação de persuadir, mobilizando o mínimo de coerção explícita para o máximo de adesão, ou seja, ele deve levar o usuário a aceitar as exigências normativas da Instituição, ao que se soma a ação "educativa" que incide sobre os valores, comportamentos e atitudes da população; sobre o seu modo de ser, de agir e de compreender a vida cotidiana. Por outro lado, a estratégia de individualização dos atendimentos possibilita aliviar as tensões e insatisfações, submetendo-as ao controle institucional.
\end{abstract}

O Serviço Social desde que tencionou romper com o conservadorismo almeja ações profissionais que ultrapassem as ações pontuais focadas no indivíduo, que envolva dimensões mais coletivas, contínuas e processuais, respeitando o sigilo profissional.

Nesse sentido, a tabela I expressa compilação extraída de CFESS (2014, p. 67-74) acerca de atribuições e competências profissionais no sistema prisional que

\footnotetext{
${ }^{40}$ Por foco no indivíduo refere-se ao indivíduo abstratamente, deslocado da realidade social que o determina. O oposto do retratado por Marx e Engels (2007) por indivíduo concreto, real.
} 
ampliam as possibilidades de trabalho (que incluem, mas igualmente ultrapassam as requisições institucionais):

TABELA I - ATRIBUIÇÕES E COMPETÊNCIAS PROFISSIONAIS NO SISTEMA PRISIONAL.

\begin{tabular}{|c|c|}
\hline Atribuição/competência & Ações profissionais \\
\hline $\begin{array}{l}\text { Avaliação social para fins } \\
\text { judiciais e/ou processos } \\
\text { avaliativos institucionais. }\end{array}$ & $\begin{array}{l}\text { - avaliação social; } \\
\text { - exame criminológico; } \\
\text { - laudos periciais; } \\
\text { - participação em comissão disciplinar; } \\
\text { - participação em comissão de avaliação laboral, convênios } \\
\text { e visitas a empresas nas quais os/as detentos/as laboram; }\end{array}$ \\
\hline Acompanhamento/orientação. & $\begin{array}{l}\text { - acompanhamento de detentos/as e famílias; } \\
\text { - orientação às populações carcerárias e a familiares sobre } \\
\text { seus direitos, orientação ao/à apenado/a sobre seus direitos } \\
\text { e deveres e sobre as normas institucionais; } \\
\text { - triagem, acolhimento e reuniões com reclusos/as; } \\
\text { - cadastro e demais procedimentos técnicos para visita } \\
\text { íntima e de crianças e adolescentes nas unidades. }\end{array}$ \\
\hline $\begin{array}{l}\text { Apoio no meio } \\
\text { externo/articulação. }\end{array}$ & $\begin{array}{l}\text { - articulação com a rede e encaminhamentos diversos, } \\
\text { encaminhamentos a setores internos; } \\
\text { - acompanhamento dos/as apenados/as a saídas para } \\
\text { trabalho e visitas a familiares; } \\
\text { - acompanhamento a egressos/as; } \\
\text { - participação dos movimentos sociais e organizativos } \\
\text { vinculados à temática sociojurídica; } \\
\text { - acompanhamento de processos junto da Defensoria } \\
\text { Pública. }\end{array}$ \\
\hline Planejamento & $\begin{array}{l}\text { - planejamento e organização de projetos de trabalho para } \\
\text { presos/as com deficiência; } \\
\text { • organização de programas voltados para a cultura (clubes } \\
\text { de leitura, concursos literários), educativos, execução de } \\
\text { atividades recreativas e desportivas, religiosas; } \\
\text { - coordenação de estudos e pesquisas na área do serviço } \\
\text { social } \\
\text { - proposição e execução de programas de preparação para a } \\
\text { liberdade, de profissionalização e progressão de regime; } \\
\text { - planejamento, organização e administração de programas } \\
\text { e projetos. }\end{array}$ \\
\hline Saúde & $\begin{array}{l}\text { - execução de programas voltados para a saúde mental; } \\
\text { - acompanhamento a consultas psiquiátricas e serviços de } \\
\text { saúde mental. }\end{array}$ \\
\hline $\begin{array}{l}\text { Recursos humanos/gestão } \\
\text { institucional }\end{array}$ & $\begin{array}{l}\text { - orientação dos/as servidores/as quanto à compreensão das } \\
\text { situações sociais envolvendo os/as presos/as; } \\
\text { • capacitação de recursos humanos; } \\
\text { - ampliação dos canais de comunicação da população } \\
\text { carcerária com a administração penitenciária; } \\
\text { - gestão do acesso à assistência religiosa pelos/as presos/as }\end{array}$ \\
\hline
\end{tabular}


As ações profissionais sistematizadas por CFESS (2014) não estão isentas de tensões, polêmicas e contradições, mas refletem um panorama nacional das atribuições e competências dos assistentes sociais no sistema prisional brasileiro, que envolve as requisições institucionais (determinadas pela LEP e outras normativas jurídicas de cada UF) e projetos profissionais das UF.

O próprio texto em questão problematiza algumas dessas ações profissionais, como a participação na Comissão Disciplinar, no Conselho de Comunidades e na elaboração de exame criminológico, assim como indica preocupações com a ausência de atuação profissional em situações referentes à saúde - pois a sistematização indicou apenas o campo da saúde mental como ação profissional - e propõem ações profissionais de pesquisa, multiprofissionais e de articulação política com movimentos sociais.

Percebe-se, em síntese, extensa dificuldade das respostas profissionais dos assistentes sociais que atuam nas prisões do Rio de Janeiro de se aproximarem da perspectiva de humanização, enquanto aproximação do humano-genérico, realizada a partir da suspensão do cotidiano.

Ou seja, existe uma limitação que não é técnica, mas social e política de realizar essa suspensão, cuja dinâmica se apresenta contraditoriamente pelas intencionalidades difusas dos profissionais e pelas funções econômica, política e ideológica das prisões, que impõem respostas burocráticas, pontuais e úteis ao capital.

\footnotetext{
A mesma dinâmica requisita dos indivíduos respostas funcionais às situações, que não demandam o seu conhecimento interno, mas tão somente a manipulação de variáveis para a consecução de resultados eficazes - o que conta não é a reprodução veraz do processo que leva um desfecho pretendido, porém o desfecho em si; no plano da cotidianidade, o critério da utilidade confunde-se com o da verdade (NETTO, 2007b, p. 68).
}

Essa condução aparentemente técnica do trabalho não se contrapõe ao caminho para uma espécie de "captura" da intersubjetividade do usuário. Como o cotidiano é a estrutura de reprodução das contradições sociais, a verdade e o saber limitam-se à experiência empírica, busca-se, na atual fase de desenvolvimento capitalista, a unidade orgânica entre ação e pensamento (ALVES, s/d) - para além da histórica conexão imediata (ou mecânica). 
Esta "integração orgânica" dirige-se a reforçar a naturalização da pena e das prisões e a admitir a baixíssima qualidade dos serviços prestados à população usuária, encerrando e aceitando a resposta profissional no desfecho em si da demanda do usuário e não no desfecho pretendido, conforme sugerido por Netto (2007b).

Há, inclusive, aquilo que Forti e Guerra (2012) criticaram: a sintonia entre senso-comum e a ação profissional. Assim, reduzem-se as potencialidades do trabalho profissional e se constrói a narrativa pseudocrítica de que as contradições das prisões são intransponíveis.

Outra observação é a dificuldade de sintonizar o Serviço Social com os novos tempos, como desafio proposto por Iamamoto (2011, p. 20) ainda no final da década de 1990: ultrapassar a execução terminal de políticas sociais e assumir um caráter propositivo, decifrando a realidade e construindo propostas "criativas e capazes de preservar e efetivar direitos". Para a autora (2011, p. 21 - grifos originais),

\begin{abstract}
Essa observação merece atenção: as alternativas não saem de uma suposta "cartola mágica" do assistente social; as possibilidades estão dadas na realidade, mas não são automaticamente transformadas em alternativas profissionais. Cabe aos profissionais apropriarem-se dessas possibilidades e, como sujeitos, desenvolvê-las, transformando-as em projetos e frentes de trabalho.
\end{abstract}

Nesse ínterim, vale abordar ao menos duas experiências exitosas que demonstram as potencialidades (ainda que contraditoriamente) do Serviço Social nas prisões, como a localização familiar (CAMARGO, 2007) e o grupo focal contra a homofobia (COSTA, 2016) - este último realizado no próprio Rio de Janeiro.

Segundo Camargo (2007), a localização de familiar parte de ações desenvolvidas pelo Serviço Social que combinam conhecimento teórico, dimensão ética e instrumentos e técnicas diversificadas no intuito de localizar familiares da pessoa privada de liberdade que teve comprometimento no vínculo sociofamiliar, classificado em três motes (a) fragilizado; (b) distendido; e (c) rompido.

A localização em si não é o fim, mas o meio para contribuir na execução da pena do preso de forma a ele ter o direito à convivência sociofamiliar 
garantido. Esse processo de trabalho exige recursos materiais, tais como computador com acesso à internet, telefone para ligações externas, inclusive de celulares, acesso ao prontuário e atuação interdisciplinar, sobretudo com a psicologia para lidar em especial com situações adversas e reações dos presos, como ansiedade em rever a pessoa potencial visitante (CAMARGO, 2007, p. 222245).

No relato de experiência de Costa (2016), o enfrentamento a criminalização da homofobia é o mote central. Esse enfretamento realizou-se a partir da técnica de grupo focal destinado exclusivamente a homossexuais presos como instrumento de combate à homofobia. Costa (2016, p. 6) expressa que os presos que participaram do grupo focal "se sentiam mais fortalecidos, disseram que foi o único setor da prisão que olharam para eles como sujeitos participativos e não como bandidos “maricas"”. Em termos de condições de trabalho, a realização do grupo precisa de um espaço reservado, cadeiras e climatização no ambiente.

As demandas estão postas na realidade implícita ou explicitamente. A análise crítica da realidade permitiu à Costa (2016) vislumbrar o grupo focal como resposta profissional a demanda da diversidade sexual. Para Lauxen e Camargo (2016), essa é uma questão duplamente invizibilizada nas prisões brasileiras, pois tanto os presos como a instituição, incluindo os assistentes sociais, não a pautam no cotidiano.

Nesse sentido,
Os espaços de construção de alteridade e promoção do reconhecimento da diversidade sexual devem iniciar por projetos que envolvam todos os trabalhadores do sistema prisional, pois não há preparo político e ético para informação dos direitos assegurados. Como exemplo o Conselho Nacional de Política Criminal e Penitenciária (CNPCP) publicou uma portaria estendendo o direito, que já era garantido aos heterossexuais desde 1999, a todos os presos com relações homoafetivas. Essa portaria não é cumprida no estado do Rio de Janeiro, o Serviço Social já fez vários expedientes às autoridades denunciando essa arbitrariedade, pois entendemos que o direito de visita íntima. Está intrinsecamente ligado à dignidade da pessoa humana. Garanti-lo apenas para casais heterossexuais é desconsiderar o princípio da igualdade (COSTA, 2016, p. 8).

Outro movimento interessante realizado pelo Serviço Social em unidade prisional deriva de pesquisa junto aos carcereiros. Em uma abordagem grupal, 
com um público que historicamente não é visto como usuário do Serviço Social, Paiuca (2014) expressa a experiência de atuação com os carcereiros (no Rio de Janeiro comumente denominado de inspetores penitenciários):

\footnotetext{
$\mathrm{O}$ trabalho realizado através de reuniões de grupos com os carcereiros da Cadeia Pública Feminina de Franca-SP foi uma ação profissional rica de reflexão sobre a realidade vivenciada. Inúmeros fatores discutidos e muitas questões consideradas estanques foram questionados, como por exemplo a efetividade e a própria intencionalidade do sistema prisional atual, os motivos das prisões, o perfil dos detentos, as condições de trabalho e o abandono enfrentado por esses trabalhadores dentro das prisões, o que abarca a falta de qualificação, baixa remuneração e o "abandono", como colocado pelos sujeitos da pesquisa. (PAIUCA, 2014, p. 75)
}

Perceba que a preocupação socioeducativa com aqueles profissionais tem potencial não aproveitável pelo Serviço Social, que no geral tem centrado suas ações aos presos e familiar e limitando-se às requisições institucionais.

Trabalhar com os inspetores penitenciários na perspectiva socioeducativa, como demonstrado, tem potencial de desnaturalizar as prisões, desvelar a criminalização da pobreza encerrada nas prisões e ainda contribuir na própria organização política dos trabalhadores, quando se questionam as condições de trabalho.

\subsection{Dificuldades de trabalho nas prisões do Rio de Janeiro.}

No eixo de dificuldades de trabalho, a partir da indagação quais são as dificuldades, destacaram-se entre as respostas dos assistentes sociais as condições de trabalho, a correlação de forças, a escassez de formação continuada e a subalternização da profissão.

Em direção semelhante às das intencionalidades difusas, impera no tema condições de trabalho o "déficit de profissionais". Perceba a partir de alguns fragmentos:

O déficit de profissionais frente ao galopante aumento da população carcerária. (AS 02)

Crescente aumento da população carcerária e redução do número de profissionais de Serviço Social. (AS 03)

Aumento quantitativo de internos e poucos profissionais para atender às demandas impostas pelo sistema prisional. Falta de recursos materiais, equipamentos e humanos. (AS 07) 
Número reduzido de profissionais para atendimento a demanda. (AS 13)

Essa relação mecânica entre quantitativo $x$ de usuários e quantitativo $y$ de profissionais deriva das análises de outras políticas sociais, que podem estar indiretamente associadas a perspectivas de controle, mas que não é necessariamente sua função precípua (ainda que não exclusivamente) como são as prisões, e de certa forma da própria luta histórica e legítima dos movimentos de trabalhadores em relação à redução da sobrecarga de trabalho, que se relaciona com a própria saúde do trabalhador. Ainda que a defesa de contratação seja algo legítimo e necessário, o horizonte abolicionista ou minimalista penal não está presentes nas críticas dos profissionais expostas nos questionários.

Cabe, entretanto, a observação de que a defesa da contratação de profissionais no contexto do encarceramento corresponde, na mesma ação, a apologia indireta da existência da instituição-prisão, carregadas das contradições que ali emanam e das funções que ali operam efetivamente.

Essa apologia indireta se reforça quando entre os fragmentos das respostas dos questionários, independente do eixo analisado, inexiste qualquer alusão à:

- Defesa da redução do quantitativo de usuários (desencarceramento), seja pela resolução dos conflitos com penas alternativas ou justiça restaurativa, seja pela liberação dos presos provisórios, seja pelo próprio fim das prisões (ainda que essas possibilidades carreguem contradições). Desde 2014, a profissão deveria, ao menos, realizar discussões acerca do abolicionismo penal e da possibilidade de sociedades sem prisões, conforme deliberação do $43^{\circ}$ Encontro Nacional do Conjunto CFESSCRESS, em 2014.

- Legalização das drogas, pois a sua ilicitude é compreendida como uma das principais formas de criminalização da pobreza. Atualmente, em torno de $1 / 4$ da população carcerária foi condenada por associação ou tráfico de drogas - esse número aumenta para algo próximo a $65 \%$ quando realizado o recorte de gênero, precisamente o caso das condenações de mulheres (MINISTÉRIO DA JUSTIÇA E SEGURANÇA PÚBLICA, 2014). O projeto profissional contrapõe-se ao tratamento das drogas como questão de segurança e propõe que o uso abusivo e prejudicial seja no âmbito da saúde pública, com ênfase na Política de Redução de Danos (CFESS, 2011 , p. 30). Após acúmulo teórico e político da categoria, expresso no item 22 do eixo "defesas dos direitos humanos" como bandeira de luta da profissão, há a "defesa da legalização e regulamentação do plantio, cultivo, produção, comercialização e consumo de drogas, submetidos a controle estatal" (CFESS, 2018, p. 9). 
- Desmilitarização da vida, que envolve o autoritarismo socialmente implantado (ou a naturalização da violência), que se constitui como o processo em que a sociedade expressa, reconhece e legitima ações autoritárias, violentas e afins, independente do regime do Estado (seja ele democrático ou autocrático) - no país, esse processo deriva da forma cruel, intensa e absoluta, que se consolidou a exploração capitalista no país, com o genocídio dos povos originários, a escravização dos povos africanos e o estupro das mulheres não-brancas -; assim como a lógica do "inimigo interno", por instituição policial, carcerária e outras, que legitimam uma relação adversarial entre frações da classe trabalhadora do próprio país. O projeto ético-político do Serviço Social expressa posicionamento contrário à militarização da vida, da política e da polícia, conforme a Carta do Rio de Janeiro, emitida ao final do $44^{\circ}$ Encontro Nacional do Conjunto CFESS-CRESS, em 2015. Esse posicionamento reflete acúmulo teórico e político da profissão que se propôs a promover debates sobre esse processo de militarização, em 2014, conforme deliberação $n^{\circ} 20$ do eixo ética e direitos humanos no $43^{\circ}$ Encontro Nacional do Conjunto CFESS-CRESS.

- Democratização da mídia, visto que sua concentração de audiência, propriedade cruzada e de mercado, sob a forte influência religiosa (INTERVOZES, 2018), corroboram para a mídia ser instrumental ideológico das classes dominantes, em uma verdadeira "legitimação publicitária da hipercriminalização dos pobres" (ZAFFARONI; BATISTA, 2003 Apud SANTOS, 2017, p.08). Para Mathiesen (2003, p. 101), "a informação fornecida pelo sistema carcerário é sistematicamente filtrada e distorcida pelos meios de comunicação de massa". Em 2015, o $44^{\circ}$ Encontro Nacional do Conjunto CFESS-CRESS aprovou moção de apoio ao Projeto de Lei de Iniciativa Popular que versava sobre a Lei da Mídia Democrática:

Posicionamo-nos, assim, pelo fim dos oligopólios e monopólios de mídia, a favor da transparência nas concessões de canais de rádio e televisão, do fortalecimento da comunicação pública e comunitária e da diversidade e da pluralidade de conteúdo nos meios de comunicação do Brasil (CFESS, 2015, p. 69).

- Função da educação formal, que não apenas fornece conhecimentos e força de trabalho qualificada ao capital, mas gera e transmite valores que legitimam a sociedade burguesa (MÉSZÁROS, 2010 Apud MELO, 2014, p. 160). Portanto, a crítica à educação formal, enquanto aparelho de hegemonia, construtora de consentimentos, deve ser lembrada quando se pensar na crítica a estrutura e superestrutura burguesa.

Outras pautas na direção abolicionista (portanto, distinta da apologia indireta) derivam do pensamento de Mathiesen (2003, p. 96). Ele propõe medidas alternativas ao encarceramento que se relacionam a um efetivo e real cuidado à vítima, atualmente abandonada, com um sistema de seguro simplificado, assim como acesso a recursos e serviços sociais aos transgressores, em forma de políticas sociais universais. 
Assim, se o Serviço Social sabe que dentre as funções das prisões tem-se necessariamente o controle e a disciplina (como funções políticas) e o estigma e a criminalização (como funções ideológicas) de fração específica da classe trabalhadora, os assistentes sociais deveriam tomar o cuidado de em suas ações profissionais e/ou defesas políticas e ideológicas de não reforçar esse estado de coisas, pois contribuem igualmente na função econômica da prisão: trata-se de consentimento passivo com as prisões como potencial fonte de lucro, incluindo a retenção temporalmente elevada dos presos. Devem-se pautar nos princípios éticos da liberdade, dos direitos humanos e da eliminação das desigualdades étnicas, com vistas à construção de outra ordem societária.

Propõe-se observar que as intencionalidades difusas dos assistentes sociais reforçam indiretamente as prisões e negligenciam a dimensão política da profissão: são ações profissionais e projeções de intervenção que raramente dialogam com deliberações do conjunto CFESS-CRESS, com a criminologia crítica e o marxismo, assim como com os movimentos sociais e populares. As prisões parecem estar naturalizadas entre os profissionais que ali atuam, ou como diria Davis (2018, p. 16) aparecem como "fato inevitável da vida, como o nascimento e a morte".

Mas o tema condições de trabalho não se esgota ao "déficit de profissionais". Os assistentes sociais expõem catarticamente as prisões como ambiente de trabalho com escassez de recursos materiais, espaços inóspitos ou inadequados destinados ao trabalho e transgressores de sigilo. A seguir alguns trechos das respostas ilustram as condições de trabalho no sentido referendado anteriormente:

\footnotetext{
$\mathrm{O}$ atendimento realizado pelo Serviço Social as famílias ocorre na $2^{\mathrm{a}}$ feira. Ocorre que sendo a demanda grande. Ocorre que o presídio neste dia também faz o atendimento à custódia. $\mathrm{O}$ que faz a porta do presídio ficar lotada de gente neste dia. O Serviço Social acaba "incomodando", demanda grande, muitas solicitações. Falta de recursos e de respeito. (AS 06)

A ausência / fragilidade na disponibilização de ferramentas da informática (equipamentos, sistemas de informações) que favoreçam o tratamento mais transparente e democrático da informação. (AS 08)

Sigilo no atendimento às famílias, acesso ao Serviço Social, instalações, instrumental (computador, ar condicionado, copiadoras. Espaço físico para atendimento às família adequado. (AS 12) Espaço de atendimento (família e interno) inadequado. (AS 13)
} 
Sala sem ar condicionado, sem móveis novos, sem telefone, computador. (AS 15)

As dificuldades são inúmeras dentre elas a falta de um espaço digno para o atendimento e externo aos familiares [...] A falta de recursos materiais e físicos. (AS 17)

As implicações, nesse contexto, são éticas e políticas, podendo implicar responsabilidade ética ao próprio assistente social (por ação ou omissão). Não se sabe se houve a informação por escrito aos responsáveis pela inadequação ética e técnica do ambiente de trabalho do assistente social, conforme determina a Resolução 493 de 21 de agosto de 2006, mas cabe relatar que, ainda segundo essa resolução, as condições éticas e técnicas obrigatórias para desempenho com qualidade dos serviços prestados por assistentes sociais envolvem local de atendimento compatível com orientação individual ou coletiva com características físicas pré-determinadas, a saber: iluminação, recursos que garantam a privacidade, ventilação e espaço adequado para reserva sigilosa de material técnico.

Outro elemento ainda no interior do tema condições de trabalho tem a ver com o vínculo empregatício e a faixa salarial. Veja alguns fragmentos que traduzem essa problemática:

Falta de planos de cargos e salários (AS 05)

Salários baixos, ausência do Plano de Cargos e Salários, profissionais que dividem a carga horária em duas unidades, falta de recursos para desenvolvimento de projetos. (AS 09)

Ausência de concurso público (ultimo realizado em 1998). Contrato temporário e precarizado de trabalho. Solicitação de desligamento pelos profissionais, agravando o quadro. (AS 11)

A ausência de concurso público desde 1998, como sugerido por um dos profissionais participantes da pesquisa e igualmente constatado em Bravin (2013a), além de abrir margem para a contratação por vínculo precário (BRAVIN, 2013b), tem contribuído para a redução de profissionais no sistema prisional.

O quadro VI demonstra que, apesar da intencionalidade difusa, é contraditoriamente legítima a queixa central das condições de trabalho ter relação com o "déficit de profissionais" e o vínculo precário.

Esse movimento de intensificação da precarização segue contrárias as propostas da ONU e do Conselho Nacional de Política Criminal e Penitenciária (CNPCP), mas são coerentes com o quinto movimento de reforma prisional. 
Segundo a ONU (1955), o trabalho nas unidades prisionais é considerado penoso. Devido ao seu caráter, a ONU propõe como regras mínimas relacionadas ao pessoal de estabelecimento prisional elementos como vínculo empregatício direto com o Estado; dedicação exclusiva; estabilidade; remuneração adequada; seleção por meio de provas teóricas e práticas; e constante aprimoramento profissional.

QUADRO VI - COMPARATIVO DO QUANTITATIVO PROFISSIONAL, SEUS VÍNCULOS E O QUANTITATIVO CARCERÁRIO.

\begin{tabular}{|ccccc|}
\hline ANO & $\begin{array}{c}\text { QUANTITATIVO } \\
\text { TOTAL }\end{array}$ & $\begin{array}{c}\text { CONTRATAÇÃO } \\
\text { ESTATUTÁRIA }\end{array}$ & $\begin{array}{c}\text { VÍNCULO } \\
\text { PRECÁRIO }\end{array}$ & $\begin{array}{c}\text { POPULAÇÃO } \\
\text { CARCERÁRIA }\end{array}$ \\
2010 & 101 & 54 & 47 & 23.158 \\
2013 & 97 & 50 & 47 & 33.000 \\
2018 & 67 & 38 & 29 & 56.372 \\
\hline
\end{tabular}

FONTE: LEMOS, 2010; BRAVIN, 2013a; CRESS/RJ, 2018; PORTAL CNJ, 2018. COMPILAÇÃO PRÓPRIA.

O CNPCP, por sua vez, desde 2009, com a Resolução de $n^{\circ} 09$ de 13 de novembro, estabelece como referência o quantitativo de 500 presos por profissional em Serviço Social, acompanhado de 6 estagiários $^{41}$. Além de ser um número elevado de presos para acompanhar, a família é desconsiderada como usuário direto do Serviço Social, quiçá os próprios trabalhadores do sistema prisional - como sugerido anteriormente com base nos estudos de Paiuca (2014).

Por outro lado, consoante com a concretude do quinto movimento de reforma prisional, essa precarização (que é histórica, mas tem se intensificado) é a expressão particular da totalidade concreta no estágio atual de acumulação e valorização do capital: reorientação do fundo público para fundos privados, banalização do mal e militarização da vida que fomentam o discurso oficial da retribuição (e seu requinte vingativo), enfraquecendo o próprio discurso oficial do ideário reformista (ressocialização, reeducação, reintegração, etc.).

$\mathrm{Na}$ mesma direção, a correlação de forças desfavorável no interior das prisões também aparece como tema no eixo das dificuldades. Alguns fragmentos mostram essas dificuldades políticas ao trabalho profissional:

\footnotetext{
${ }^{41}$ Essa proporcionalidade demonstra desconhecimento ou abstração da Resolução do CFESS $n^{\circ}$ 533 de 29 de setembro de 2008, que define no máximo 1 estagiário para cada 10 horas semanais de trabalho. Como a carga horária semanal máxima é de 30 horas, o quantitativo máximo de estagiários deveria ser de 3 estudantes devidamente inscritos na disciplina de Supervisão de Estágio.
} 
A correlação de força tendo em vista a diretriz contra hegemônica do Serviço Social. (AS 02)

Procedimentos arbitrários da direção e inspetores. (AS 05)

Violência verbal por parte dos inspetores (AS 05)

Falta de respeito em todos os sentidos. (AS 07)

Os objetivos institucionais que são impostos como objetivos profissionais. (AS 10)

Interferência dos outros profissionais (inspetores e diretor) solicitando atendimento diferenciado para alguns internos. (AS 13)

As dinâmicas de controle que se expressam e caracterizam a instituição também atravessam os procedimentos burocráticos que viabilizam as parcerias. (AS 18)

Essas dificuldades reforçam a hipótese da intencionalidade difusa e se agregam a desvalorização da luta de classes ou desconhecimento da dimensão política própria da profissão. Isso ocorre porque os fragmentos demonstram que entre a razão e a vontade dos assistentes sociais existe um abismo: reconhece-se uma correlação de forças desfavorável, mas há baixa intencionalidade e busca de meios para altera-la, pois quando se pretende algo se restringe a movimentos endógenos, no interior da própria profissão - como o eixo de possibilidades demonstrará.

Registra-se oportunamente que, inclusive, é dever do assistente social em relação às instituições empregadoras, expresso em seu Código de Ética (CFESS, 2012, p. 31), “contribuir para a alteração da correlação de forças institucionais, apoiando as legítimas demandas de interesse da população usuária”.

Também aparece no eixo de dificuldades o tema relacionado à subalternização profissional, citado como ausência de reconhecimento profissional. Em síntese, os profissionais relatam como dificuldades:

Falta de reconhecimento do trabalho no âmbito da Secretaria de Estado de Administração Penitenciária e Governo (AS 01)

Ao profissional é a falta de respeito e a falta de reconhecimento do profissional (AS 06)

Opta-se por subalternização profissional em detrimento de ausência de reconhecimento profissional porque, como demonstrado ao longo do estudo, o Serviço Social cumpre papel ímpar nas prisões, cumprindo as requisições institucionais com maestria (seja consciente ou inconscientemente, assim como com intencionalidades difusas). Sendo, portanto, essa ausência de reconhecimento profissional muito mais produto da consciência social dos profissionais, 
relacionado (ou não) a autoimagem da profissão, do que propriamente resultante da história ${ }^{42}$.

Assim, a denúncia de ausência de reconhecimento traduz, na realidade concreta, a subalternidade da profissão, pois as dificuldades relatadas não questionam a importância do Serviço Social nas prisões, mas determinam o lugar subalterno da profissão no ambiente em questão. Iamamoto (2004) assim define o significado social da profissão, demonstrando sua subalternidade na divisão social e técnica do trabalho:

O Serviço Social, como profissão, situa-se no processo de reprodução das relações sociais, fundamentalmente como uma atividade auxiliar e subsidiária no exercício do controle social e na difusão da ideologia da classe dominante entre a classe trabalhadora (IAMAMOTO, 2004, p. 100 - grifos originais).

Essa subalternidade é reforçada pelo aparente caráter difuso e heterogêneo das tarefas do Serviço Social (IAMAMOTO, 2004, p. 42), assim como a marca histórica de ser uma profissão predominantemente feminina, que carrega consigo toda a construção social e histórica do que é ser mulher em uma sociedade patriarcal (CISNE, 2012, p. 22).

\subsection{Violação de direitos nas prisões a partir do olhar dos assistentes sociais.}

No eixo de violação de direitos, a partir da questão "o que você identifica como violação de direitos", houve uma preocupação dos profissionais de distinguir o agente violado: presos, familiares ou profissionais. Para ilustrar segue alguns fragmentos:

As condições de trabalho do assistente social (tanto para os profissionais quanto para os presos e seus familiares). (AS 02)

As condições obscenas em que os presos vivem e que são submetidos seus familiares. (AS 02)

\footnotetext{
${ }^{42}$ Essa constatação não faz da ausência de reconhecimento profissional algo secundário, sobretudo se considerada na perspectiva da saúde do trabalhador. Resgatando Dejours, Santos e Manfroi (2015, p. 191) articulam o sofrimento no trabalho à falta de reconhecimento profissional: "Para o autor, 'quando a qualidade de meu trabalho é reconhecida, também meus esforços, minhas angústias, minhas dúvidas, minhas decepções, meus desânimos adquirem sentido'. Assim, quando o trabalho não é reconhecido, perde seu significado como algo que pode transformar o sofrimento em prazer. Desta forma, 'o reconhecimento não é uma reivindicação secundária dos que trabalham. Muito pelo contrário, mostra-se decisivo na dinâmica da mobilização subjetiva da inteligência e da personalidade no trabalho"”.
} 
Essa distinção revela o quão complexo é o campo da execução penal. Expõe que o cotidiano prisional, em sincronia com os estágios de acumulação e valorização do capital, necessita de permanentes violações e violências para cumprir suas funções e mesmo se legitimar enquanto instituição de retribuição, incluindo os próprios trabalhadores que ali atuam.

Focada na garantia da lei e da ordem no intramuros sob o discurso oficial de retribuição e prevenção (geral e especial), a existência das prisões é a expressão cabal das contradições sociais e da verticalidade da sociedade capitalista: fragmenta a classe trabalhadora nas prisões em bandidos, trabalhadores da segurança (inspetores penitenciários) e técnicos de nível superior; e fomenta a relação adversarial inclusive no seu próprio interior: inspetores penitenciários $x$ presos; inspetores penitenciários $x$ técnicos; técnicos $x$ presos - um estado de tensão permanente, forjado pelas lutas econômicas em torno do controle do mercado denominado ilegal (em especial o comércio varejista de drogas tipificadas ilegais) e dos circuitos legais da economia no interior das prisões (que envolve desde a cantina e os serviços terceirizados às privatizações - portanto, a disputa pelo controle, administração ou execução da funcionalidade econômica das prisões ao processo de acumulação e valorização do capital) e retroalimentado pela função ideológica das prisões.

Mas em geral situa os inspetores penitenciários acima do bem e do mal, em que o tema arbítrio, no eixo de violação de direitos, ilustra essa complexidade. Perceba em alguns fragmentos:

Aos usuários é o abuso de poderes. (AS 06)

A cultura prisional focada na segurança é também uma dificuldade a ser enfrentada. (AS 08)

Inspetores penitenciários que tomam atitudes sem concordância do Serviço Social. (AS 14)

Comissão Técnica de Classificação por motivos fúteis. (AS 14)

Não se trata de erro individual dos trabalhadores ali inseridos, mas de reprodução (consciente ou inconscientemente) das funcionalidades das prisões. Esse processo inclui a relativização da própria legislação (daí a assertiva de situar acima do bem e do mal). A inobservância da lei - expressa no eixo de violação de direitos - aparece como tema das respostas dos profissionais. Ao mesmo tempo em que revela certa ingenuidade ou apologia indireta à existência das prisões, 
demonstra a característica permanente do cotidiano prisional: são espaços desumanos, degradantes e cruéis para todos que ali se inserem. Os fragmentos a seguir expõem a problemática da inobservância da lei:

Falta de cumprimento do que já está estabelecido, a exemplo cumprimento de regime semiaberto sem direito à saídas externas. (SEAP 01)

Superlotação das unidades prisionais, descumprimento das leis em vigor (LEP e RPERJ) no que concerne aos direitos dos presos, visto que o serviço a eles oferecidos é precário em todos os sentidos. (SEAP 18)

No Brasil, desde a primeira Constituição, ainda em 1824, há a preceituação de que as prisões deveriam se adequar a parâmetros de estrutura física e arquitetônica e garantir certos direitos aos presos. Amaral (2016, p. 102-105) expressa que historicamente o Poder Público justificou essa inobservância da lei a partir do discurso oficial da prevenção geral positiva (a ideia da prisão como instituição que controla o crescimento da criminalidade por meio do medo), da escassez de financiamento público à política penal e da ausência de tempo hábil para realizar as mudanças necessárias.

$\mathrm{Ou}$ seja, para as autoridades políticas do Brasil, independente das condições ambientais das prisões e de sua lotação, a prisão deveria receber novos sujeitos para supostamente controlar o aumento da criminalidade e, caso haja dinheiro e tempo, poder-se-ia mudar aquela realidade com obras ou alimentação adequada.

Portanto, as prisões são historicamente violadoras de direitos assumido e reconhecido pelo Estado. Esse cotidiano de arbítrio e inobservância da lei conforma os processos de trabalho no interior das prisões. Assim, os assistentes sociais revelam ainda no eixo de violação de direitos o tema privação aos serviços. Perceba em alguns fragmentos a situação de privação:

Controle de quem tem acesso ao Serviço Social, bem como os demais serviços (AS 15)

A "negação" de acesso às políticas públicas e serviços aos quais tem direito, ainda com cidadão em situação de prisão. Um dado muito importante é o extravio de documentação da pessoa presa, impasses burocráticos que dificultam a concretização de serviços que atendam as demandas por direitos. (AS 19)

Os assistentes sociais indicam como violação de direitos as dificuldades ou mesmo a impossibilidade de acesso a diversos serviços: a privação de serviços 
aparece como fenômeno cotidiano de usuários, familiares e dos próprios assistentes sociais. Em geral, as respostas se referem aos direitos à saúde, educação e trabalho, assim como o próprio acesso ao Serviço Social - sejam por dificuldade ou controle de acesso por parte da instituição ou mesmo de outros profissionais, como o inspetor penitenciário, sejam por inexistência do profissional em Serviço Social na própria unidade prisional.

Perceba que ao se tratar dos direitos dos presos a LEP inicia sua proposta dita humanizadora pela negação dos direitos em seu artigo $3^{\circ}$ : "ao condenado e ao internado serão assegurados todos os direitos não atingidos pela sentença ou lei”.

Embora defina um elenco de direitos aos presos no artigo 41, tais como assistência material, à saúde, jurídica, educacional, social e religiosa, o ponto de partida da execução penal é a negação do direito - preceituado no artigo $3^{\circ}$-, alguns inclusive dependentes diretos do comportamento do preso sob a perspectiva do inspetor penitenciário ou diretor da unidade prisional (considerada tendencialmente de arbítrio, como um dos temas sugere). Entretanto, essas ações não são erros ou desvios individuais e isolados, mas próprios da dinâmica da prisão.

As variadas reformas prisionais mostram a tentativa de humanização da pena - baseada em aspectos ora físicos e arquitetônicos (seja para fins de aprimoramento de vigilância, ou mesmo para adequação ambiental, como as de ventilação - em geral considerados determinantes ambientais relacionados a doenças respiratórias, como a tuberculose); ora de regime penitenciário (incluindo construções de presídios para grupos de presos específicos) no intuito de aumentar a disciplina e o controle e/ou o trabalho produtivo dos presos - em que um olhar histórico-crítico permite a constatação que todas essas tentativas foram frustrantes, pois o traço comum de violações, violências e privações de serviços persistiu.

Esse eixo nos mostra que o discurso oficial de prevenção especial positiva (os ideais reformistas) não se concretiza. Igualmente demonstra que a regra do cotidiano prisional é a sua função política de controle e disciplina, sem abrir mão de arbitrariedade, inobservância da lei e privação de serviços, afetando não apenas os presos, mas se estendendo aos familiares e aos profissionais da própria instituição. 
A explicação desse cotidiano prisional constante, que inclusive superou variados movimentos de reformas e que se intensifica com o quinto movimento, é revelada por Rusche e Kirchheimer (2004): trata-se do princípio da less elegibility. É o princípio pelo qual a vida na prisão não pode ser superior aos estratos mais baixos da classe trabalhadora livre, na medida em que para o capital devem-se resguardar mecanismos políticos e ideológicos para constranger à classe ao trabalho alienado, proteger a propriedade privada e resguardar os efeitos da pena.

Portanto, a relação entre prisão e violação de direitos é indissociável, visto que as tentativas de reformas no intuito de humanizar a pena mostra, por um lado, o fracasso de mudanças significativas e, por outro lado, a permanência do princípio da less elegibility.

\subsection{As possibilidades de trabalho dos assistentes sociais nas prisões.}

Ao ser analisado o eixo de possibilidades de trabalho, optou-se por agrupar partes das respostas em articulações intraprofissionais, por se referirem à necessidade de alterar parte da dinâmica de trabalho com articulações entre os próprios profissionais. A seguir alguns fragmentos (grifos não originais):

\footnotetext{
Vejo que é necessária uma maior articulação interna de modo que pudéssemos refletir mais profundamente sobre as estratégias e até mesmo o realinhamento no projeto de atuação profissional na Secretaria de Estado de Administração Penitenciária (redefinição de estratégias, propósitos e instrumental técnico-operativo). (AS 08) Reunião com grupo de trabalho a fim de viabilizar estratégias de ação para que o profissional tenha sua identidade clara (AS 09)

O Serviço Social na Secretaria de Estado de Administração Penitenciária deveria redefinir o plano de atuação, deveria reorganizar a proposta de intervenção. Deixar de focar-se em questões burocráticas e que não correspondem ao real. (AS 16)
}

Acontece que nas prisões fluminenses os profissionais do Serviço Social parecem acreditar que a resolução das dificuldades de trabalho estaria em uma reorganização da sua própria intervenção, que não estaria correspondendo às demandas dos usuários e que seu papel ainda é nebuloso.

Existe, assim, uma tripla dimensão autoimplicada quanto às articulações intraprofissionais defendidas como possibilidades de trabalho nas prisões: (i) um deslocamento da inserção do Serviço Social na divisão social e técnica do trabalho 
no interior das prisões, em que ele ideologiza e distingue a sua função dos processos reais e concretos de trabalho na prisão. Assim, seu objeto de trabalho aparece como distinto dos demais profissionais. Ou, como sugere Lemos (2010), o objeto é igual ao dos demais (a custódia), mas seu reconhecimento causa constrangimento, pois o permite se perceber como Agente do Estado em uma instituição privativa de liberdade e violadora de direitos; (ii) esse deslocamento somado à redução da profissão à dimensão técnico-operativa traduz uma concepção de profissão destoante ao do projeto ético-político (ainda que inconscientemente); (iii) a implicação desse processo é a crise de identidade profissional, que pode estar ligada ao tensionamento entre imagem social e autoimagem profissional, assim como aos objetivos institucionais e aos objetivos do profissional (ou da profissão).

Todo esse processo conduz o assistente social nas prisões a acreditar que é apenas enquanto possibilidade de trabalho que se pode pensar em articulações, sejam elas intraprofissionais, sejam elas políticas - e prevalecendo em ambas o movimento endógeno de resolutividade da problemática que perpassa seu cotidiano de trabalho.

Assim, na perspectiva dos assistentes sociais que atuam nas prisões do Rio de Janeiro, atividades profissionais como articulação política e rede socioassistencial estão situadas prevalentemente como temas do eixo de possibilidades de trabalho, e não efetivamente (apesar de citado) no de respostas profissionais às demandas como demonstrado no item correspondente.

Sugerido pelos profissionais partícipes da pesquisa como possibilidade de trabalho, o tema articulação política assim aparece entre os fragmentos dos questionários analisados da seguinte maneira:

\footnotetext{
As lutas coletivas através do órgão de representação (Associação de servidores denominados técnicos), do Cress / Cfess. (AS 02)

Fortalecimento de ações no Cress - sociojurídico (AS 04)

Articulação com Cress, órgãos da categoria e da sociedade civil ligadas ao sistema penitenciário (AS 05)

A união dos profissionais: (A modificação, diante dos inspetores penitenciários, do trabalho do corpo técnico dentro da unidade) (AS 06)
}

Relegar ao campo das possibilidades de trabalho a dimensão política do Serviço Social, em detrimento de respostas profissionais, pode sugerir uma 
desvalorização das lutas de classes ou desconhecimento do caráter da própria profissão.

É indissociável do trabalho profissional a contradição entre reprodução e continuidade da sociedade de classes e possibilidades de sua transformação (YAZBEK, 2014, p. 685). Sem incorrer na supervalorização da dimensão política da profissão, as respostas profissionais, enquanto mediações de projetos individuais, coletivos e societários, são atravessadas por disputas políticas e lutas por hegemonia.

Assumir lado, nesse processo, ocorre independente da vontade do profissional: por omissão ou ação, ao menos um dos lados é assumido, tendencialmente o das classes dominantes. No entanto, o projeto profissional indica caminho alinhado ao da classe trabalhadora.

Assim, constitui-se princípio ético dos assistentes sociais a "articulação com os movimentos de outras categorias profissionais que partilhem dos princípios do Código [de Ética] e com a luta geral dos/as trabalhadores/as" (CFESS, 2012, p. 24); consiste-se em direito do assistente social "apoiar e/ou participar dos movimentos sociais e organizações populares vinculados à luta pela consolidação e ampliação da democracia ${ }^{43}$ e dos direitos de cidadania ${ }^{44 "}$ (CFESS, 2012, p. 34); assim como concebe como uma de suas competências profissionais "prestar assessoria e apoio aos movimentos sociais em matéria relacionada às políticas sociais, no exercício e na defesa dos direitos civis, políticos e sociais da coletividade" (CFESS, 2012, p. 45).

Ou seja, a dimensão política do Serviço Social é assumidamente do lado daqueles que se propõe a (re) construir o mundo, e não apenas no interior da profissão, como sugerem os fragmentos selecionados. Tampouco essa dimensão se reduz à possibilidades de trabalho, mas situa-se como relação indissociável do trabalho profissional.

Em relação ao tema rede socioassistencial, ainda no eixo das possibilidades de trabalho, percebe-se a dificuldade de sua articulação e de acesso a informações a sua existência. Segue os fragmentos que ilustram isso:

\footnotetext{
${ }^{43}$ Por democracia o código de ética compreende a socialização da participação política e da riqueza socialmente construída.

${ }^{44}$ Por cidadania o código a concebe a partir do reconhecimento da divisão geracional proposta por Marshall: direitos civis, políticos e sociais.
} 
Feedback dos recursos institucionais externos. (AS 07)

Investimento na formação de rede inter e extra institucional com um melhor fluxo de informação com os gestores para a formulação de estratégias de um trabalho mais coadunado com as demandas. (AS 19)

As dificuldades relacionadas à rede socioassistencial, quando analisadas articuladamente com outras contribuições teóricas, demonstram (i) os aspectos de ausência ou dificuldades de políticas públicas para o setor, assim como sua gestão e execução pela Igreja ou pelo chamado Terceiro Setor (ARAÚJO, 2017); (ii) a lógica própria da política social de atomização da "questão social", intervindo sobre um aspecto da problemática em detrimento da perspectiva da totalidade concreta da vida social (NETTO, 2007a); e (iii) os próprios sujeitos envolvidos superpopulação relativa -, destinado terminalmente às políticas penal ou assistencial (WACQUANT, 2011).

Em síntese, as possibilidades de trabalho nas prisões para os assistentes sociais que ali atuam são, na realidade concreta, elementos próprios do trabalho profissional, mas que tanto pelas requisições institucionais quanto pela concepção de profissão dos assistentes sociais são relegadas à possibilidades, e não como respostas profissionais. 


\section{CONSIDERAÇÕES FINAIS}

Ao longo da dissertação, buscaram-se demonstrar que as prisões cumprem funções econômicas, políticas e ideológicas, ocultadas pelos discursos oficiais. São espaços de criminalização da superpopulação relativa, associando-a as classes perigosas, movimentando variados nichos de mercado (inclusive, os considerados ilegais) e mobilizando trabalhadores para ali (ou em mercados indiretos, como a segurança privada e a indústria bélica) atuarem profissionalmente.

As prisões, enquanto espaço de cumprimento da pena privativa de liberdade, surgiram para humanizar a pena, que outrora era as de castigo corporal ou a própria morte. Esta humanização, no entanto, não se materializou, visto que historicamente as prisões têm condições desumanas, degradantes e cruéis.

Tentativas de reformas prisionais ocorreram para alterar essa realidade. Compreendem-se ao menos cinco movimentos: reforma moral; estrutura física; regimes penitenciários; expansão de presídios e regime de segurança supermáxima; e contrarreformas. Todas em vão no sentido de humanizar a prisão. Porém, cumpriram outros papeis, como intensificação do controle e da vigilância.

Um desses movimentos de reforma, alinhado ao processo de aumento da intervenção do Estado, no estágio monopolista do capital, passou a requisitar profissões das Ciências Humanas e Sociais, dentre elas o Serviço Social.

O Serviço Social historicamente foi requisitado para operar nas prisões as reformas morais, ou reajustamento do preso. Teve como variáveis empíricas para isso desde ações recreativas à oferta de serviços concretos, com doações recolhidas nos comércios e indústrias. Assim, a marca histórica da profissão nas prisões é o assistencialismo e o controle.

A LEP ao mesmo tempo em que ampliou as requisições institucionais ao Serviço Social reduziu à profissão à ações terminais, pontuais, assistencialistas, fiscalizatórias e controladoras. No Rio de Janeiro, o RPERJ atribui novos papeis ao Serviço Social e perpetua requisições históricas.

Inseridos nesse contexto, em 2015, os assistentes sociais quando questionados sobre suas demandas nas prisões, embora distingam o demandante, assimilam as requisições institucionais como demandas, a saber: Situação Jurídica; Visita Excepcional; Visita entre presos; Visita íntima; Cancelamento e Reconsideração de cancelamento de carteira de visitante; Registros de nascimento 
e reconhecimento de paternidade; Ingresso de crianças; Movimentação de Pequenos Valores; Previdência/Auxílio Reclusão; Documentação Civil; Assistência Religiosa; e Comissão Técnica de Classificação.

Em suma, a profissão se situa na "linha de frente", a chamada "porta de entrada", para distinguir entre os que não terão direito e os que potencialmente terão direitos. Suas demandas (que na realidade são requisições institucionais) são em geral de informação e trâmite burocrático.

A assimilação entre requisição e demanda contribui no reforço ideológico do direito como benefício, sobretudo quando o principal critério de elegibilidade para uma gama de direitos aos presos é o comportamento, a disciplina, associando direito e ajuda. Essa limitação das demandas às requisições institucionais demonstra uma dupla dinâmica: (i) esvaziamento do conteúdo de classe das demandas e requisições institucionais; e (ii) cristalização do trabalho profissional e o consequente fortalecimento das funções econômica, política e ideológica das prisões ao capital.

Quanto às respostas profissionais a essas demandas, percebeu-se que as intencionalidades dos profissionais são difusas, conjugando ecleticamente perspectivas e valores antagônicos, e sugerem ações baseadas no senso-comum e que contribuem no consentimento ativo e passivo dos usuários. Apreendeu-se existência de associação ou assimilação entre instrumentos e técnicas com as respostas profissionais (inclusive, entre algumas demandas). Em síntese, o foco das ações profissionais nas prisões do Rio de Janeiro foi de cunho terminal e pontual.

Esses profissionais indicam como dificuldades de trabalho nas prisões as condições de trabalho, a correlação de forças desfavorável e a subalternidade da profissão.

Em relação às condições de trabalho, os assistentes sociais indicaram preocupações com o "déficit de profissionais"; os espaços inóspitos ou inadequados ao trabalho e transgressores do sigilo; e os vínculos empregatícios precários e faixa salarial baixa. Essas indicações sugerem uma apologia indireta à instituição-prisão e uma possível desvalorização ou desconhecimento da dimensão ético-política da profissão e, ao mesmo tempo, constatam o movimento de contrarreforma prisional e o reforço do discurso oficial da retribuição. 
A desfavorabilidade da correlação de forças indicada como dificuldade e a forma como foi apresentada pelos profissionais sugeriram uma baixa intencionalidade de busca para sua alteração.

Inicialmente indicada pelos assistentes sociais como ausência de reconhecimento profissional, outra dificuldade do trabalho profissional nas prisões percebida foi a subalternidade da profissão. Essa mudança de ausência de reconhecimento profissional para subalternidade profissional ocorreu pela apreensão de que a profissão cumpre papel ímpar nas prisões, que seu lugar na divisão social e técnica do trabalho em seu interior é reconhecido e necessário. Assim, as dificuldades indicadas se relacionaram ao caráter difuso e heterogêneo das tarefas do Serviço Social, a papel auxiliar e subsidiário da profissão e a predominância de mulheres em uma sociedade patriarcal, mostrando um lugar subalterno nas prisões.

Igualmente, os profissionais indicaram como violações de direitos: a inobservância da lei, o arbítrio e a privação de serviços. Essas violações e violências não são erros individuais. Mas são elementos constitutivos e constituintes da prisão historicamente. Nenhum dos movimentos de reforma prisional alterou essa realidade. Pelo contrário, as contrarreformas em curso intensificam a gravidade das relações sociais no interior das prisões.

Frente a esse quadro, os profissionais sugerem como possibilidades de trabalho as articulações intraprofissional e política (que se limitaram à própria profissão), assim como a rede socioassistencial (aparentemente desconhecida e não realizada por parte significativa dos profissionais). Percebeu-se que dimensões do trabalho profissional foram relegadas ao campo das possibilidades, e ali permaneceram - não sendo, portanto, respostas profissionais no cotidiano de trabalho.

Considera-se um quadro caótico em relação ao trabalho profissional nas prisões do Rio de Janeiro. Porém, mudanças são próprias da história. Nada é estático. Um novo reconhecimento profissional, a partir de seus usuários, pode ser galgado. Portanto, o desafio histórico do Serviço Social nas prisões do Rio de Janeiro é o mesmo da profissão no geral: construir novas bases de legitimidade.

Esse processo pode ser subsidiado pelo projeto ético-político, inclusas as deliberações do conjunto CFESS-CRESS, que orienta para a construção de outra ordem societária sem desigualdades sociais, a partir da articulação com 
organizações de outras categorias e movimentos sociais e populares, que estejam interessados em reformular o código penal, abolir o exame criminológico e refletir sobre a possibilidade de um mundo sem prisões: afinal, a permanência da existência da prisão representa a continuidade das contradições sociais e da verticalidade do capitalismo. 


\section{REFERÊNCIAS BIBLIOGRÁFICAS REFERÊNCIAS BIBLIOGRÁFICAS}

ALVES, Giovanni. A disputa pelo intangível: estratégias gerenciais do capital na era da globalização. In: ANTUNES, Ricardo (org.). Riqueza e miséria do trabalho no Brasil. São Paulo: Boitempo, s/d.

AMARAL, Cláudio do Prado. A história da pena de prisão. Jundiaí: Paco Editorial, 2016.

ANDRADE, Vera Lucia. Horizonte de projeção do controle penal no capitalismo globalizado neoliberal. In: BATISTA, Vera Malaguti; ABRAMOVAY, Pedro Vieira (orgs.). Depois do grande encarceramento. 2012.

ARAÚJO, Carlos Eduardo Moreira de. O Duplo Cativeiro: Escravidão urbana e o sistema prisional no Rio de Janeiro, 1790 - 1821. Rio de Janeiro: UFRJ/IFCS. 2004.

ARAÚJO, Débora Cristina. Serviço Social e Sistema Penal: considerações sobre a assistência prestada à egressos do sistema penitenciário. In: Anais da VIII Jornada Internacional de Políticas Públicas, realizada na Universidade Federal do Maranhão, entre 22 e 25 de agosto de 2017.

BARATTA, Alessandro. Criminologia crítica e crítica do direito penal. Rio de Janeiro: Revan: Instituto Carioca de Criminologia. $6^{\circ} \mathrm{Ed}$, outubro de 2011. $3^{\circ}$ Reimpressão, agosto de 2016.

BRAVO, Maria Inês Souza; CORREIA, Maria Valéria Costa. Desafios do controle social na atualidade. In: Revista Serviço Social e Sociedade. 2012, n.109, pp.126-150.

BECCARIA, Cesare. Dos delitos e das penas. Rio de Janeiro: Editora Rio, 2004.

BRASIL. Lei de Execução Penal. Lei no 7.210 de 11 de julho de 1984.

Decreto Federal $\mathbf{n}^{0}$ 35.076. Aprova o Regulamento da Penitenciária Central do Distrito Federal. Disponível em http://legis.senado.leg.br/norma/457667/publicacao/15699218 Acesso em 14/04/2019.

BRAVIN, Rita Marilza. Serviço Social e sistema penitenciário: um estudo sobre a possibilidade de materialização das diretrizes do atual projeto éticopolítico do serviço social brasileiro. Dissertação (mestrado) - Universidade do Estado do Rio de Janeiro. Rio de Janeiro: UERJ/ESS, 2013.

Serviço social e sistema penitenciário: um estudo sobre flexibilização de direitos do trabalho. In: Anais do $\mathbf{1 4}^{\circ}$ Congresso Brasileiro de Assistentes Sociais, realizado em Águas de Lindoia, entre 14 e 18 de outubro de 2013. São Paulo: CFESS, 2013. 
CAMARGO, Saulo. Prisão e abandono: trabalhando a localização de familiar no sistema prisional. In: Libertas, Juiz de Fora, v.6 e 7, n. 1 e 2, p. 222 - 245, jan-dez / 2006, jan-dez / 2007.

CHIES, Luiz Antônio Bogo. PASSOS, Rodrigo Azevedo. Auxílio-reclusão: a bizarra transmutação de um direito social e sua colonização perversa por um populismo punitivo. In: Textos \& Contextos (Porto Alegre), v. 11, n. 2, p. 273 291, ago./dez. 2012.

CISNE, Mirla. Gênero, Divisão Sexual do Trabalho e Serviço Social. 1. ed. São Paulo: Outras Expressões, 2012.

COELHO, Marilene. Imediaticidade na Prática Profissional do Assistente Social. In: FORTI, Valeria e GUERRA, Yolanda. Serviço Social: temas, textos e contextos. $2^{\text {a }}$ Ed. Rio de Janeiro: Lumen Juris, 2012.

CONCEIÇÃO, João Rafael da. Serviço Social e a assimilação da punição:é possível um Serviço Social punitivo?. Trabalho de Conclusão de Curso apresentado como requisito parcial para obtenção do título de bacharel em Serviço Social na Escola de Serviço Social da Universidade Federal do Estado do Rio de Janeiro, em junho de 2016. (mimeo).

CONSELHO FEDERAL DE SERVIÇO SOCIAL (CFESS). Atuação de assistentes sociais no Sociojurídico: subsídios para reflexão. Brasilía: CFESS, 2014.

Código de Ética do/a assistente social / lei $\mathrm{n}^{\mathbf{0}} \mathbf{8 . 6 6 2 / 9 3}$ de regulamentação da profissão. 10ª Ed. Brasília: CFESS, 2012.

CONSELHO REGIONAL DE SERVIÇO SOCIAL - $7^{\mathrm{a}}$ REGIÃO (CRESS/RJ). COMISSÃO SOCIOJURÍDICO. Serviço Social no campo sociojurídico: subsídios para o exercício profissional. Rio de Janeiro: CRESS, 2018.

COSTA, Newvone. Ferreira. A criminalização da homofobia na prisão. Enfrentamento do Serviço Social. In: Anais do XV Encontro Nacional de Pesquisadores/as em Serviço Social, organizado pela Associação Brasileira de Ensino e Pesquisa em Serviço Social, em 2016.

DANTAS, Rosilene. PEREIRA, Tania Maria Dahmer. Notas reflexivas sobre a relação de custódia e o exercício profissional: o caso do Hospital de Custódia e Tratamento Psiquiátrico. In: FORTI, Valéria. GUERRA, Yolanda (org.). Ética e Direitos Humanos: ensaios críticos. Rio de Janeiro: Lumen Juris, 2009.

DAVIS, Ângela. Estarão as prisões obsoletas. Rio de Janeiro: DIFEL, 2018.

DEMANDA. In: DICIO, Dicionário online de português. Porto: 7Graus, 2019. Disponível em https://www.dicio.com.br/demanda/. Acesso em 25/05/2019.

DUARTE, Thaís Lima. Amor em cárcere: Relações afetivas no sistema penitenciário do Rio de Janeiro. Tese (Doutorado) - Universidade do Estado do 
Rio de Janeiro (UFRJ), Instituto de Filosofia e Ciências Humanas (IFCH), Programa de Pós-Graduação em Ciências Sociais (PPCIS), 2015.

ENGELS, Friedrich. O papel do trabalho na transformação do macaco em homem. In: ANTUNES, Ricardo. (Org.) A dialética do trabalho: escritos de Marx e Engels. São Paulo: Expressão Popular, 2013. (p. 11-28)

FERREIRA, Lusilene. A prática do assistente social da saúde no sistema prisional de Goiás, no município de Luziânia. Trabalho de Conclusão de Curso (Artigo) apresentado ao curso de especialização Lato Sensu em Serviço Social, Justiça e Direitos Humanos, da Universidade Católica de Brasília, como requisito parcial para obtenção do Título de especialista em Serviço Social, Justiça e Direitos Humanos. Brasília: UCB, 2014.

FERREIRA, Edlene Santiago. OLIVEIRA, Maria Francenilda Gualberto. A atuação do assistente social no Sistema Penitenciário: estudo de caso da saúde básica das apenadas do regime semiaberto na cidade de Manaus. In: Anais do II Congresso de Assistentes Sociais do Estado do Rio de Janeiro. Rio de Janeiro, 2016.

FORTI, Valeria Lucilia. Ética e serviço social: formalismo, intenção ou ação? Um estudo nos hospitais de custódia e tratamento psiquiátrico do Estado do Rio de Janeiro. Rio de Janeiro: UFRJ, 2008.

FORTI, Valeria. GUERRA, Yolanda. Na prática a teoria é outra? In: FORTI, Valeria e GUERRA, Yolanda. Serviço Social: temas, textos e contextos. $2^{\mathrm{a}} \mathrm{Ed}$. Rio de Janeiro: Lumen Juris, 2012.

FOUCAULT, Michel. Vigiar e Punir. Nascimento das prisões. $41^{\text {a }}$ Ed. Rio de Janeiro: Vozes, 2014.

FREITAS, Cristiano Rodrigues de. (et al.). Fragmentos de discursos (não tão amorosos) sobre o Exame Criminológico - Um livro falado. Rio de Janeiro: Conselho Regional de Psicologia do Rio de Janeiro, 2013.

GONÇALVES, Isabel Cristina Lima. As competências profissionais do assistente social no desenvolvimento do processo de inclusão social no sistema penitenciário: um estudo em Palmas. In: Revista Humanidades e Inovação v.4, n. $5-2017$.

GUERRA, Yolanda Aparecida Demetrio. REPETTI, Gustavo Javier. FILHO, Antonio Andrade. SILVA, Platini Boniek Sardou. ALCANTARA, Elton Luiz da Costa. Atribuições, competências, demandas e requisições: o trabalho do assistente social em debate. In: Mesa Temática Coordenada: Fundamentos do trabalho do/a assistente social no contexto de reconfiguração das políticas sociais no Brasil no XV Encontro Nacional de Pesquisadores/as em Serviço Social, organizado pela Associação Brasileira de Ensino e Pesquisa em Serviço Social, em 2016.

IAMAMOTO, Marilda. O Serviço Social na contemporaneidade: trabalho e 
formação profissional. $21^{\mathrm{a}}$ Ed. São Paulo: Cortez, 2011.

- Serviço Social em tempo de capital fetiche: capital financeiro, trabalho e questão social. $6^{\text {a }}$ Ed. São Paulo: Cortez, 2011 b.

O Serviço Social na Cena contemporânea. In: CFESS. ABEPSS (org.). Serviço Social: direitos sociais e competências profissionais. CEAD/UnB. Brasília. 2009.

Renovação e conservadorismo no Serviço Social. $7^{\text {a }}$ Ed. São Paulo: Cortez, 2004.

IAMAMOTO, Marilda. CARVALHO, Raul. Relações Sociais e Serviço Social no Brasil: esboço de uma interpretação histórico-metodológica. São Paulo: Cortez; [Lima, Peru]: 2012.

INTERVOZES - Coletivo Brasil de Comunicação Social. Quem Controla a mídia no Brasil?. Disponível em http://brazil.mom-rsf.org/br/ Publicado em 2018.

KONDER, Leandro. O que é a dialética. 28ª ed. São Paulo: Brasiliense 2000.

O marxismo na batalha das ideias. São Paulo: Expressão Popular, 2009.

LAUXEN, Iarani Augusta Galúcio; CAMARGO, Caroline Cristine Costa. O trabalho de assistentes sociais na garantia de direitos a população LGBT em cumprimento de pena privativa de liberdade. In: Anais do Congresso LatinoAmericano de Gênero e Religião. São Leopoldo: EST, v. 4, 2016.

LEMOS, Amanda dos Santos. "É mais fácil condenar quem já cumpre pena de vida": um estudo sobre a prática profissional sobre o assistente social no sistema penitenciário. Dissertação (mestrado). Apresentada ao Programa de Pósgraduação em Serviço Social da Faculdade de Serviço Social da Universidade do Estado do Rio de Janeiro. 2010. (235 f.)

LENIN, Vladimir Ilitch. O Estado e a Revolução: o que ensina o marxismo sobre o Estado e o papel do proletariado na revolução. $1^{a}$ Ed. São Paulo: Expressão Popular, 2007.

LUKÁCS, Georg. As Bases Ontológicas do Pensamento e da Atividade do Homem. In: Ontologia Social, Formação Profissional e Política. Caderno do Núcleo de Estudos e Aprofundamento Marxista (NEAM), $n^{\circ}$ 1. São Paulo: PUC/SP, 1997, p. 8-64.

MARCOSIN, Cleir. Documentação em Serviço Social Debatendo a Concepção Burocrática e Rotineira. In: FORTI, Valeria e GUERRA, Yolanda. Serviço Social: temas, textos e contextos. $2^{\text {a }}$ Ed. Rio de Janeiro: Lumen Juris, 2012.

MARQUES, Simone Felix. O Desacreditável e o Desacreditado: Considerações sobre o fazer técnico do Assistente Social no Sistema Prisional. 
Artigo elaborado para a Superintendência de Serviços Penitenciários do Estado do Rio de Grande do Sul (SUSEPE RS), em 2009.

MARX, Karl. População, criminalidade e pauperismo. Publicado pela primeira vez no New York Daily Tribune, n. 5.741, 16 set. 1859. In: Verinotio revista online - n. 20. Ano X, out./2015, ISSN 1981-061X

O Capital. Crítica da economia política. Livro I. Volume II. $10^{a}$ Edição. São Paulo: DIFEL, 1985. (p. 828 - 882).

O Capital. Crítica da economia política. Volume I. Livro Primeiro: o processo de produção do capital. Tomo 1 (prefácios e capítulos I a XII). São Paulo: Nova Cultural, 1996a. (coleção os economistas)

O Capital. Crítica da economia política. Volume I. Livro Primeiro: o processo de produção do capital. Tomo 2 (capítulos XIII a XXV). São Paulo: Nova Cultural, 1996b. (coleção os economistas)

Para a questão judaica. São Paulo: Expressão Popular, 2009.

MARX, Karl. ENGELS, Friedrich. Manifesto Comunista. São Paulo: Instituto José Luis e Rosa Sundermann, 2003.

A ideologia Alemã. São Paulo: Expressão Popular, 2007.

MATHIESEN, Thomas. A caminho do século XXI - abolição um sonho possível? In: Revista Verve, Nº4. São Paulo: PUC-SP, 2003.

MELO, Camila Gibin. Entre Muros e Grilhões: criminologia crítica e a práxis de enfrentamento contra o sistema penal e pelo fim das prisões. Dissertação (mestrado) apresentada à Faculdade de Serviço Social da Pontifícia Universidade Católica do Rio de Janeiro. São Paulo: PUC SP, 2014.

MINISTÉRIO DA JUSTIÇA. DEPARTAMENTO PENITENCIÁRIO NACIONAL. Levantamento Nacional de Informações Penitenciárias (INFOPEN) - Atualização de 2014. Brasília: Ministério da Justiça e Segurança Pública. Departamento Penitenciário, 2016. 65 p.

MINISTÉRIO DA JUSTIÇA E SEGURANÇA PÚBLICA. DEPARTAMENTO PENITENCIÁRIO NACIONAL. Levantamento Nacional de Informações Penitenciárias (INFOPEN) - Atualização de 2016. Brasília: Ministério da Justiça e Segurança Pública. Departamento Penitenciário, 2017. 65 p.

NASCIMENTO, Leidiane Pereira. Um Estudo sobre exame criminológico e Serviço Social no sistema penal. In: Anais do $\mathbf{1 4}^{\circ}$ Congresso Brasileiro de Assistentes Sociais, realizado em Águas de Lindoia, entre 14 e 18 de outubro de 2013. São Paulo: CFESS, 2013.

NETTO, José Paulo. Ditadura e Serviço Social: uma análise do Serviço Social no Brasil pós-64. 16 ${ }^{\text {a }}$ Ed. São Paulo: Cortez, 2011. 
III CBAS: Algumas Referências para a sua Contextualização. In: 30 Anos do Congresso da Virada / Conselho Federal de Serviço Social (CFESS) (organizador), Conselho Regional de Serviço Social - S. Paulo (CRESS-9 ${ }^{\text {a }}$. Região), Associação Brasileira de Ensino e Pesquisa em Serviço Social (ABEPSS), Executiva Nacional de Estudantes de Serviço Social (ENESSO) (coorganizadores). - Brasília, 2009.

Cinco notas a propósito da "questão social”. In: Capitalismo Monopolista e Serviço Social. São Paulo: Cortez, 2007.

Capitalismo Monopolista e Serviço Social. São Paulo: Cortez, 2007a.

Para a crítica da vida cotidiana. In: CARVALHO, Maria do Carmo Brant; NETTO, José Paulo. Cotidiano: conhecimento e crítica. $7^{\mathrm{a}}$ Ed. São Paulo: Cortez, 2007b.

A crítica conservadora à reconceptualização. In: Revista Serviço Social \& Sociedade, São Paulo: Cortez, n. 5, 1981.

OLIVEIRA, Ednéia Alves. Superpopulação relativa e "nova questão social": um convite às categorias marxianas. In: Revista Katálasys. Florianópolis v. 13 n. 2 p. 276-283 jul./dez. 2010

OLIVEIRA, Pedro Rocha. Paradigmas de Política Penal e sentido econômico da população: das punições corporais às UPPs. In: EM PAUTA, Rio de Janeiro _ 10 Semestre de 2016 - n. 37, v. 14, p. 243 - 269.

OLIVEIRA, Edistia Maria Abath Pereira. CHAVES, Helena Lúcia Augusto. 80 anos do Serviço Social no Brasil: marcos histórico balizados nos códigos de ética da profissão. In: Revista Serviço Social e Sociedade. São Paulo, n. 128, p. 143163, jan./abr. 2017

ORGANIZAÇÃO DAS NAÇÕES UNIDAS (ONU). Regras Mínimas das Nações Unidas para o Tratamento de Reclusos (Regras de Nelson Mandela). 1955.

ORTIZ, Fátima da Silva Grave. O Serviço Social e sua Imagem: avanços e continuidades de um processo em construção. Rio de Janeiro: UFRJ, Escola de Serviço Social, 2007. 303 f.

PAIUCA, Juliana Martinatti. A experiência do trabalho do Serviço Social junto aos carcereiros da cadeia feminina de Franca/SP. Dissertação (mestrado) apresentada à Faculdade de Ciências Humanas e Sociais, Universidade Estadual Paulista "Júlio de Mesquita Filho", como pré-requisito para obtenção do Título de Mestre em Serviço Social. Franca: UNESP, 2014.

PANIAGO, Maria Cristina Soares. Marx, Mészáros e o Estado. São Paulo: Instituto Lukács, 2012. 
PEREIRA, Tania Maria Dahmer. Quando o camburão chega antes do SAMU: Notas Sobre os Procedimentos Técnico-Operativos do Serviço Social. In: FORTI, Valéria; GUERRA, Yolanda. Serviço Social: Temas, Textos e Contextos. Coletânea Nova de Serviço Social. Rio de Janeiro: Editora Lumen Juris, 2010.

Um estudo dos valores do assistente social na sua pratica no sistema penitenciário do Rio de Janeiro. Dissertação (mestrado) - Pontifícia Universidade Católica do Rio de Janeiro, Departamento de Serviço Social, 1984. Bibliografia: f.127-133.

QUEIROZ, Maristela Gomes. BORBA, Dandrea Mouro. PICHELLI, Daniele Padovan. OLIVEIRA, Juliene Aglio. Reflexão do Serviço Social frente às demandas do centro de detenção provisória, central de penas e medidas alternativas e central de atendimento ao egresso. In: Seminário Integrado, Presidente Prudente, v. 03, 2009 (p. 106-126). ISSN 1983-0602.

REISHOFFER, Jefferson Cruz; BICALHO, Pedro Paulo Gastalho. A circunscrição histórica das prisões e a crítica criminológica In: FARIAS, Francisco Ramos; FACEIRA, Lobelia da Silva. Punição e prisão: ensaios críticos. Rio de Janeiro: Lumen Juris, 2015.

RUIZ, Jefferson Lee. Para que servem e a quem interessam as prisões? Reflexões sobre a necessidade e a possibilidade de uma sociedade sem aprisionamento. Exposição oral no III Seminário Estadual Serviço Social e Direitos Humanos, organizado pelo CRESS/RJ e realizado entre 18 e 19 de fevereiro de 2016 (mimeo).

RUSCHE, Georg. KIRCHHEIMER, Otto. Punição e Estrutural Social. $2^{\mathrm{a}}$ Ed. Rio de Janeiro: Revan, 2004.

SANTOS, Célia Maria de Abreu. História da Divisão de Serviço Social do Sistema Penal do Estado do Rio de Janeiro - de sua criação até 1985. Dissertação de Mestrado. PUC Rio de Janeiro, 1987.

SANTOS, Claudia Monica. FILHO, Rodrigo de Souza. BACKX, Sheila. A dimensão técnico-operativa do Serviço Social: questões para reflexão. In: SANTOS, Claudia Mônica. BACKX, Sheila. GUERRA, Yolanda (org.). A dimensão técnico-operativa no Serviço Social: desafios contemporâneos. $3^{\text {a }}$ Ed. São Paulo: Cortez, 2017.

SANTOS, Silvana Marcelina. O horror na periferia do capital: um estudo sobre a crise social e o discurso punitivo no jornalismo popular. In: Revista Libertas, Juiz de Fora, v.17, n.1, p. 01-26, jan. a jul. / 2017.

SANTOS, Maria Teresa; MANFROI, Vania Maria. Condições de trabalho das/os assistentes sociais: precarização ética e técnica do exercício profissional. In: EM PAUTA, Rio de Janeiro _ 2o Semestre de 2015 - n. 36, v. 13, p. 178 - 196.

SERRA, Marco Alexandre de Souza. Economia Política da Pena. Dissertação (mestrado). Curitiba: Faculdade de Direito/Universidade Federal do Paraná, 2007. 
SOUZA, José Paulo de Morais. O sistema penitenciário sob a ótica do trabalho. In: FARIAS, Francisco Ramos; FACEIRA, Lobelia da Silva. Punição e prisão: ensaios críticos. Rio de Janeiro: Lumen Juris, 2015.

VALERAI, Ibaranês Fátima Bertoldo. O papel do Serviço Social no Sistema Penitenciário do Paraná: análise crítica da fundamentação legal da profissão. Artigo apresentado no curso de Pós-Graduação em Gestão da Questão Social e Política Social. Faculdade Educacional de Medianeira. Medianeira, agosto 2012.

VASCONCELOS, Ana Sílvia Furtado. FACEIRA, Lobelia da Silva. RIBEIRO, Mariangela Pavão. SILVA, Normélia Maria. O Serviço Social no sistema penitenciário no estado do Rio de Janeiro. In: Anais do XI Congresso Brasileiro de Assistentes Sociais. Fortaleza, 2004.

WACQUANT, Loic. As prisões da miséria. 2a Ed. Rio de Janeiro: Zahar, 2011.

O lugar da prisão na nova administração da pobreza. In: Novos estudos CEBRAP $\mathrm{n}^{\mathrm{o}}$ 80. São Paulo Mar. 2008. (p.09-19) Disponível em http://www.scielo.br/scielo.php?script=sci_arttext\&pid=S010133002008000100002 , acesso em 11/01/2019. 